\begin{abstract}
UNIVERSIDADE DE SÃO PAULO
ESCOLA DE ENGENHARIA DE SÃO CARLOS

DEPARTAMENTO DE HIDRÁULICA E SANEAMENTO

PROGRAMA DE PÓS-GRADUAÇÃO EM ENGENHARIA HIDRÁULICA E SANEAMENTO
\end{abstract}

\title{
DESEMPENHO DE REATOR ANAERÓBIO DE LEITO FLUIDIFICADO OPERADO SOB CONDIÇÕES DE AUMENTO PROGRESSIVO DA CARGA ORGÂNICA NO TRATAMENTO DE FENOL
}

Eduardo Lucena Cavalcante de Amorim

São Carlos 


\section{DESEMPENHO DE REATOR ANAERÓBIO DE LEITO FLUIDIFICADO OPERADO SOB CONDIÇÕES DE AUMENTO PROGRESSIVO DA CARGA ORGÂNICA NO TRATAMENTO DE FENOL}

Eduardo Lucena Cavalcante de Amorim

Dissertação apresentada a Escola de Engenharia de São Carlos, da Universidade de São Paulo, para obtenção do titulo de Mestre em Hidráulica e Saneamento.

Orientador: Prof. Dr. Edson Luiz Silva

São Carlos 


\section{AUTORIZO A REPRODUÇÃO E DIVULGAÇÃO TOTAL OU PARCIAL DESTE TRABALHO, POR QUALQUER MEIO CONVENCIONAL OU ELETRÔNICO, PARA FINS DE ESTUDO E PESQUISA, DESDE QUE CITADA A FONTE.}

Ficha catalográfica preparada pela Seção de Tratamento da Informação do Serviço de Biblioteca - EESC/USP

Amorim, Eduardo Lucena Cavalcante de
A524d Desempenho de reator anaeróbio de leito fluidificado operado sob condições de aumento progressivo da carga orgânica no tratamento de fenol / Eduardo Lucena Cavalcante de Amorim ; orientador Edson Luiz Silva. São Carlos, 2007.

Dissertação (Mestrado-Programa de Pós-Graduação e Área de Concentração : Hidráulica e Saneamento) -- Escola de Engenharia de São Carlos da Universidade de São Paulo, 2007.

1. Tratamento biológico de águas residuárias. 2. Leito fluidificado. 3. Fenol. 4. biofilme. I. Título. 
FOLHA DE JULGAMENTO

Candidato: Engenheiro EDUARDO LUCENA CAVALCANTE DE AMORIM

Dissertação defendida e julgada em 28-03-2007 perante a Comissão Julgadora:

$\frac{\text { Godson S. Silva Aprovado }}{\text { Prof. Dr. EDSON LuIZ SILVA (Orientador) }}$

(Escola de Engenharia de São Carlos/USP)

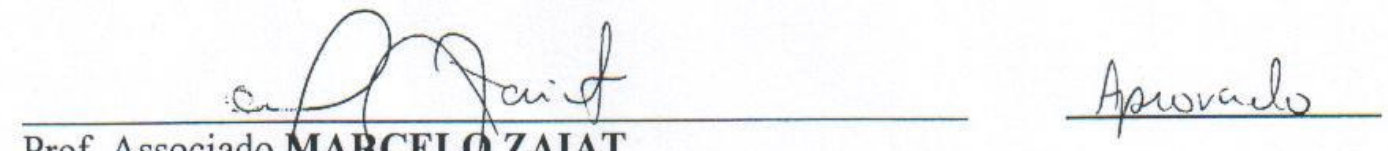

Prof. Associado MARCEL $\phi$ ZAIAT

(Escola de Engenharia de Sáo Carlos/USP)
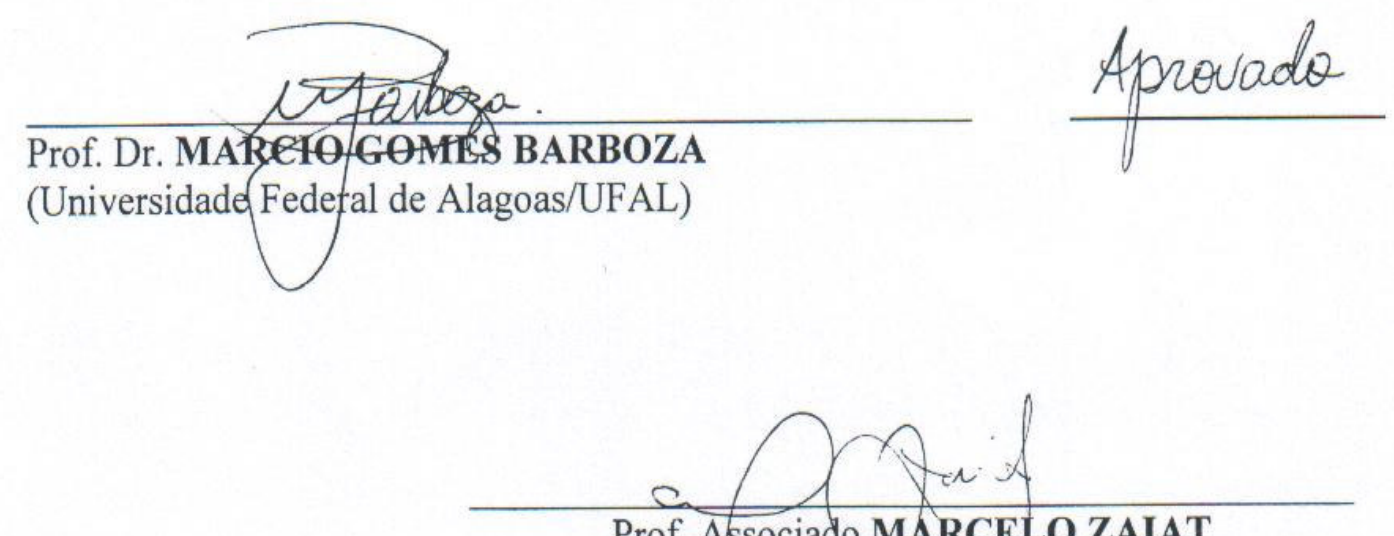

Prof. Associado MARCELO ZAIAT

Coordenador do Programa de Pós-Graduação

em Engenharia (Hidráulica e Saneamento)

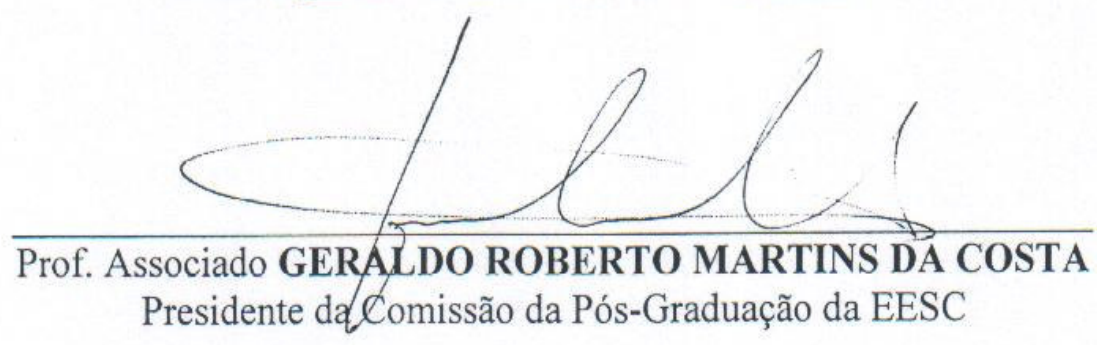


À minha esposa Evilania Amorim com Amor.

Aos meus pais Ivanerjes Amorim e Selma Amorim, a minha irmã Vanessa Amorim. 
"Quem possui a sabedoria obterá a glória em herança: para onde quer que vá, o Senhor abençoa."

(Eclo 4,13) 


\section{AGRADECIMENTOS}

Agradeço primeiramente a Deus, que é o maior responsável pela realização deste trabalho. Quero também mostrar minha gratidão a todos que de alguma forma contribuíram para a realização desta dissertação, mais especialmente a:

Meus pais, Ivanerjes e Selma Amorim, irmã Vanessa Amorim, ao Josias Lima, e demais familiares, tios e primos, que são a grande motivação de nosso sucesso; pelas suas demonstrações de confiança e compreensão.

À minha esposa Evilania Amorim, pelo amor, dedicação, compreensão e pela ajuda nas horas difíceis, onde soube "segurar a barra" mesmo à distância, juntamente com sua família, Maria Francisca (Tinha), José Luiz, Sebastião Neto (Neto). Todos têm um lugar especial no meu coração.

Aos meus avós, Alpiniano e Maria Lucena Marques, José Amancio e Marinete Amorim, por todo apoio e carinho.

Ao Prof $^{0}$. Dr $^{\circ}$. Edson Luiz Silva por acreditar e ter grande confiança em minha pessoa; pela eficácia orientação dedicada e principalmente pela amizade formada durante esses anos de trabalho.

À Prof $^{\mathrm{a}}$. Dr ${ }^{\mathrm{a}}$ Maria Bernadete A. Varesche pela sua co-orientação.

Aos meus tios Severino e Dilze Marques por terem sido exemplo para mim e por todo apoio e incentivo.

Ao amigo Marcus Vasconcelos pela amizade e por todo apoio e confiança dados durante a etapa de graduação e seleção do mestrado.

Ao técnico Oscar da Silva, pela construção do reator e pela ajuda realizada durante o desenvolvimento do trabalho. 
Ao Prof ${ }^{\circ}$. Titular Eugênio Foresti pela oportunidade em participar do Projeto Temático.

Ao Prof $^{0}$. Dr $^{0}$. Marcelo Zaiat pelas sábias orientações na qualificação e durante o andamento do trabalho.

À Prof ${ }^{a}$. Elisabete Mattos Moraes do Departamento de Hidráulica e Saneamento da Escola de Engenharia de São Carlos - EESC/USP pelas análises de ácidos voláteis por cromatografia.

Ao Esmeraldo Cappelaro pela ajuda nas análises cromatográficas.

Ao Julio, que me ensinou algumas técnicas das análises laboratoriais aplicadas neste trabalho.

Ao meu grande amigo $\operatorname{Prof}^{0}$. $\operatorname{Dr}^{0}$. Márcio Barboza, pela contribuição e incentivo para a minha aprovação no mestrado.

Ao $\operatorname{Prof}^{0}$. Dr$^{0}$. Roberaldo Carvalho pelo aprendizado adquirido durante a graduação.

À Prof $^{\mathrm{a}}$. Dr ${ }^{\mathrm{a}}$. Cleuda Freire, por todo o aprendizado e iniciação na produção de artigos científicos.

Aos meus ex-professores da Universidade Federal de Alagoas.

Aos amigos que fazem parte da colônia Alagoana e aos agregados, Antonio Netto, Gustavo Codá, André Dória, Saulo Almeida, Eduardo Toledo, Rafael Piatti, Walter Oliveira, Suzana, Luiz Gustavo, Rômulo Farias, Pedro, Sylvia Paes, Claudius Barbosa, Valter Cléber, Paulino Almeida, Jorge Pantoja, Walter Ferreira e outros.

Ao amigo Alexandre Rocha pela grande ajuda dada durante todo o desenvolvimento do experimento, principalmente "segurando a barra" durante minhas férias, onde tornou possível rever minha esposa e família.

À Maressa Cuel pela grande ajuda dada durante o desenvolvimento do trabalho.

Aos demais colegas do Laboratório de Controle Ambiental II pelos momentos de descontração e pela companhia. 
Ao $\mathrm{Sr}^{\mathrm{o}}$. Nelson Gallo do Instituto de Física da Universidade de São Carlos pelas análises de microscopia eletrônica de varredura.

Um especial agradecimento ao meu amigo e companheiro Antonio Pedro (Netto), pessoa com quem convivi durante maior parte do meu mestrado e que esteve sempre ao meu lado nos momentos de alegria, lazer e estresses.

À Érika Sarti, Ana Carolina e Iolanda pelas análises microscópicas.

Aos amigos de Maceió que compreenderam a minha ausência em certas ocasiões, mas que sempre estiveram no meu coração.

Ao CNPq e FAPESP pelo apoio financeiro e pelo investimento no Laboratório de Controle Ambiental II do Departamento de Engenharia Química da Universidade Federal de São Carlos - UFSCar. 


\section{RESUMO}

AMORIM, E.L.C. (2007). Desempenho de reator anaeróbio de leito fluidificado operado sob condições de aumento progressivo da carga orgânica no tratamento de fenol. Dissertação (Mestrado) - Escola de Engenharia de São Carlos, Departamento de Hidráulica e Saneamento, Universidade de São Paulo, São Carlos.

O fenol e seus derivados são poluentes comumente presentes nos efluentes industriais. Também são considerados poluentes orgânicos perigosos e difícieis de serem eliminados, quando presentes em altas concentrações. O processo de tratamento anaeróbio é uma alternativa para a degradação de despejos que possuem compostos persistentes, como fenóis. O objetivo deste trabalho foi estudar a viabilidade do uso de reator anaeróbio de leito fluidificado (RALF) operado sob condições de aumento progressivo da carga orgânica no tratamento de água residuária sintética contendo fenol como única fonte de carbono. O reator foi construído em acrílico com altura de $190 \mathrm{~cm}$ e diâmetro interno de $5 \mathrm{~cm}$, e volume total de $4192 \mathrm{~cm}^{3}$. O meio suporte foi constituído por partículas de poliestireno $(2,2 \mathrm{~mm})$. O inóculo utilizado foi lodo de abatedouro de suínos, o tempo de detenção hidráulica (TDH) foi 24 h, o RALF foi operado a $30 \pm 1{ }^{\circ} \mathrm{C}$ durante 182 dias. A adaptação do inóculo ocorreu no próprio reator, onde permitiu uma partida rápida, 14 dias, além de manter as condições de anaerobiose no reator. As concentrações de fenol tratadas foram de $50 \mathrm{mg} / \mathrm{L}, 100 \mathrm{mg} / \mathrm{L}, 200 \mathrm{mg} / \mathrm{L}, 300$ mg/L, 400 mg/L, 500 mg/L, 600 mg/L e 700 mg/L, com taxas de carregamento orgânico real aplicadas de 0,09 a 1,29 $\mathrm{kg}$ fenol $/ \mathrm{m}^{3}$ dia. $\mathrm{O} \mathrm{pH}$ variou entre 6,59 e 8,21 para todo o sistema. As concentrações de alcalinidade a bicarbonato (AB) afluente e efluente foram $180 \mathrm{mg} / \mathrm{L} \mathrm{e}$ 294 mg/L, respectivamente. Foram constatadas eficiências de remoção de fenol e de DQO superiores a $90 \%$ e $88 \%$, respectivamente. De um modo geral, os resultados mostraram a potencialidade do sistema proposto em degradar efluentes líquidos contendo fenol.

Palavras-chaves: Processo anaeróbio, leito fluidificado, fenol e biofilme. 


\begin{abstract}
AMORIM, E.L.C. (2006). Performance of anaerobic reactor of fluidized bed operated under conditions of progressive increase of the organic load in the phenol treatment. Dissertation - School of Engineering of São Carlos, Department of Hydraulics and Sanitation, University of São Paulo, São Carlos.
\end{abstract}

The phenol and yours derived they are pollutant commonly presents in the industrial effluents. They are also considered pollutant organic dangerous and difficult of they be eliminated, when presents in high concentrations. The process of anaerobic treatment is an alternative for the degradation of spillings that possess composed persistent, as phenols. The objective of this work was to study the viability of the use of anaerobic fluidized-bed reactor (RALF) operated under conditions of progressive increase of the organic load in the treatment of synthetic wastewater containing phenol as only source of carbon. The reactor was built in acrylic with height of $190 \mathrm{~cm}$ and internal diameter of $5 \mathrm{~cm}$, and total volume of $4192 \mathrm{~cm}^{3}$. The half supports was constituted by particles of polystyrene $(2,2 \mathrm{~mm})$. The used sludge was the mud of slaughterhouse of swine, the time of hydraulic detention (TDH) it was $24 \mathrm{~h}$, RALF was operated $30 \pm 1{ }^{\circ} \mathrm{C}$ for 182 days. The adaptation of the sludge happened in the own reactor, where it allowed a fast departure, 14 days, besides maintaining the anaerobic conditions in the reactor. The phenol concentrations treated were of $50 \mathrm{mg} / \mathrm{L}, 100 \mathrm{mg} / \mathrm{L}, 200 \mathrm{mg} / \mathrm{L}, 300 \mathrm{mg} / \mathrm{L}$, $400 \mathrm{mg} / \mathrm{L}, 500 \mathrm{mg} / \mathrm{L}, 600 \mathrm{mg} / \mathrm{L}$ and $700 \mathrm{mg} / \mathrm{L}$, where the taxes of real organic shipment applied varied from 0,09 to $1,29 \mathrm{~kg}$ fenol/ $\mathrm{m}^{3}$ dia. The $\mathrm{pH}$ varied between 6,59 and 8,21 for the whole system. The alkalinity concentrations to bicarbonate $(\mathrm{AB})$ influent and effluent were $180 \mathrm{mg} / \mathrm{L}$ and $294 \mathrm{mg} / \mathrm{L}$, respectively. Efficiencies of phenol removal were verified and of superior DQO to $90 \%$ and $88 \%$, respectively. In general, the results showed the potentiality of the system proposed in degrading liquid effluent containing phenol.

Key-words: Process anaerobic, fluidized bed, phenol and biofilm. 


\section{SUMÁRIO}

Resumo $\quad$ i

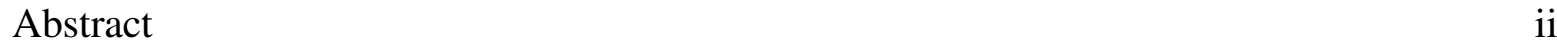

Lista de Figuras $\quad$ vi

Lista de Tabelas $\quad$ X

Lista de Símbolos e Abreviações $\quad$ xii

CAPÍTULO 1 INTRODUÇÃO

1.1 Introdução 1

1.2 Objetivos 4

CAPÍTULO 2 REVISÃO BIBLIOGRÁFICA

$\begin{array}{ll}2.1 \text { Generalidades } & 5\end{array}$

2.2 Aspectos referentes ao fenol e ao metabolismo anaeróbio $\quad 7$

2.2.1 Fenol 7

2.2.2 Compostos Fenólicos 8

2.2.3. Metabolismo da degradação microbiana de fenóis sob condições anaeróbias $\quad 10$

$\begin{array}{ll}\text { 2.2.3.1 Fontes de fenol no ambiente } & 10\end{array}$

2.2.3.2 Rotas da biodegradação do fenol $\quad 11$

2.2.3.3 Rota redutiva 11

2.2.3.4 Rota da carboxilação 12

2.2.3.5 Carboxilação e decarboxilação 16

2.2.3.6 Sob condições metanogênicas 18

2.3 Aspectos referentes ao reator anaeróbio de leito fluidificado 20

2.3.1 Reator anaeróbio de leito fluidificado 20 
2.3.2 Desenvolvimento de biofilmes

2.3.3 Formação de biofilme na partida e operação de reatores de leito fluidificado

2.3.4 Taxa de carregamento orgânico em reatores biológicos

2.3.5 Biorreatores empregados para o tratamento anaeróbio de fenol

3.1 Reator anaeróbio de leito fluidificado

3.2 Água residuária sintética

3.3 Inóculo

3.4 Suporte empregado no reator anaeróbio de leito fluidificado

3.5 Adaptação do inóculo ao fenol e início da operação

3.6 Métodos analíticos

3.6.1 Determinação de ácidos voláteis por cromatografia

3.6.2 Caracterização microbiológica do biofilme anaeróbio

3.6.3 Determinação da produção de metano

3.6.4 Exame microscópico

CAPÍTULO 4 RESULTADOS E DISCUSSÕES

4.1 Adaptação do inóculo ao fenol

4.2 Degradação anaeróbia de fenol em reator anaeróbio de leito fluidificado

4.2.1 Remoção de fenol para reator preenchido com partículas de poliestireno

4.3 Demais parâmetros monitorados

4.4 Efeito do aumento progressivo da carga orgânica

4.5 Produção e análise da formação do biogás 
CAPÍTULO $5 \quad 109$

$\begin{array}{ll}5.1 \text { Conclusões } & 109\end{array}$

5.2 Sugestões 111

REFERÊNCIAS BIBLIOGRÁFICAS 112

$\begin{array}{ll}\text { ANEXOS } & 121\end{array}$ 


\section{LISTA DE FIGURAS}

Figura 2.1 Fórmula estrutural do fenol.

Figura 2.2 Rotas propostas na degradação anaeróbia do fenol

Figura 2.3 Produtos resultantes da transformação de monofluofenóis a monofluorobenzoatos via para-carboxilação

Figura 2.4 Carboxilação do fenol.

Figura 2.5 Decarboxilação do fenol.

Figura 2.6 Transformação do fenol para benzoato via 4-

hidroxibenzoato sob condições metanogênicas

Figura 3.1 Esquema da instalação do reator anaeróbio de leito fluidificado

Figura 3.2 Reator anaeróbio de leito fluidificado

Figura 3.3 Distribuidor de alimentação

Figura 3.4 Topo do reator

Figura 3.5 Reservatório de alimentação 51

Figura 3.6 Partículas de poliestireno 54

Figura 3.7 Esquema da instalação do reator anaeróbio de leito 56 fluidificado durante a etapa de partida

Figura 4.1 Variação temporal da degradação do fenol na adaptação do inóculo

Figura 4.2 Morfologias observadas na adaptação do inóculo: bacilos, víbrios e morfologias semelhantes a Methanosaeta sp..

Figura 4.3 Variação da vazão efluente ao longo do tempo para o reator preenchido com poliestireno 
Figura 4.4 Variação temporal da concentração de fenol afluente $(--)$,

efluente $\left(\star^{\star}\right)$ e eficiência de remoção de fenol $\left(^{\circ}\right)$ para o reator anaeróbio de leito fluidificado

Figura 4.5 Variação temporal da DQO afluente $(-)$, efluente $\left(\star^{-}\right)$e eficiência de redução de DQO $\left(^{\circ}\right)$ para o reator anaeróbio de leito fluidificado

Figura 4.6 Variação temporal do $\mathrm{pH}$ afluente $(-)$ e efluente $\left(\star^{-}\right)$para o reator anaeróbio de leito fluidificado

Figura 4.7 Variação temporal da alcalinidade a bicarbonato afluente 86 $(-)$ e efluente $\left(\star^{-}\right)$para o reator anaeróbio de leito fluidificado

Figura 4.8 Variação temporal dos ácidos voláteis totais afluente (-) e efluente $(\star-)$ para o reator anaeróbio de leito fluidificado

Figura 4.9 Variação temporal da Taxa de Carregamento Orgânico Aplicada (*) e Removida () relacionada ao fenol para o reator anaeróbio de leito fluidificado

Figura 4.10 Efeito da carga orgânica de fenol aplicada em relação à concentração de fenol afluente $(-)$, efluente $\left({ }^{*}\right)$ e a eficiência de remoção de fenol $\left(^{\circ}\right)$ para o reator anaeróbio de leito fluidificado.

Figura 4.11 Variação da Taxa de Carregamento Orgânico Aplicada relacionada a DQO com a concentração de DQO afluente $\left({ }^{-}\right)$e efluente $\left({ }^{-}\right)$e a eficiência de redução de DQO $\left(^{\circ}\right)$ para o reator anaeróbio de leito fluidificado 
Aplicada (口) relacionada a DQO e eficiência de remoção de fenol $(\bullet)$ para o reator anaeróbio de leito fluidificado.

Figura 4.13 Variação temporal da produção do biogás no reator anaeróbio de leito fluidificado

Figura 4.14 Adesão das células e formação de biofilme nas partículas de poliestireno para a fase II, concentração de $100 \mathrm{mg} / \mathrm{L}$ no $57^{\circ}$ dia de operação (a) Cocos, bacilos retos e morfologias semelhantes à Methanosaeta sp., (b) bacilos curvos, bacilos ovalados e cocos, (c) bacilos curvos, bacilos ovalados e cocos, (d) bacilos curvos, bacilos ovalados, cocos e filamentos delgados, (e) bacilos curvos, bacilos ovalados, cocos e filamentos delgados e (f) Matriz gelatinosa, cocos e morfologias semelhantes à Methanosarcina sp.

Figura 4.15 Adesão das células e formação de biofilme nas partículas de poliestireno para a fase IV, concentração de $300 \mathrm{mg} / \mathrm{L}$ no $118^{\circ}$ dia de operação (a) bacilos ovalados, (b) bacilos ovalados, cocos, espirilos, bacilos curvos, (c) espirilos, bacilos curvos, bacilos ovalados, bacilos retos e morfologias semelhantes à Methanosarcina sp., (d) filamentos, bacilos ovalados, cocos e bacilos curvos, (e) bacilos ovalados, cocos, filamentos e bacilos curvos e (f) bacilos ovalados, cocos, filamentos e bacilos curvos

Figura 4.16 Adesão das células e formação de biofilme nas partículas de poliestireno para a fase $\mathrm{V}$, concentração de $400 \mathrm{mg} / \mathrm{L}$ no 
$128^{\circ}$ dia de operação (a) espiroquetas, espirilos e bacilos ovalados, (b) bacilos ovalados, bacilos retos, (c) bacilos retos, cocos, bacilos ovalados, (d) bacilos retos, cocos, bacilos ovalados, filamentos, bacilos curvos, (e) cocos e bacilos e (f) bacilos retos, cocos, bacilos ovalados, filamentos, bacilos curvos

Figura 4.17 Adesão das células e formação de biofilme nas partículas de poliestireno para a fase VI, concentração de $500 \mathrm{mg} / \mathrm{L}$ no $151^{\circ}$ dia de operação (a) bacilos curvos, morfologias semelhantes à Methanosaeta sp., cocos e bacilos ovalados, (b) bacilos curvos, morfologias semelhantes à Methanosaeta sp., cocos e bacilos ovalados, (c) espirilos, filamentos, bacilos curvos, (d) espiroquetas, morfologias semelhantes à Methanosaeta sp., (e) espiroquetas, filamentos e bacilos e (f) cocos, bacilos ovalados e filamentos

Figura 4.18 Adesão das células e formação de biofilme nas partículas de poliestireno para a fase VIII, concentração de $700 \mathrm{mg} / \mathrm{L}$ no $177^{\circ}$ dia de operação (a) cocos e bacilos, (b) bacilos ovalados, (c) bacilos, (d) bacilos, (e) cocos e bacilos e (f) bacilos e morfologias semelhantes à Methanosaeta sp.

Figura 4.19 Variação temporal dos Sólidos Suspensos Voláteis (SSV) afluente $(-)$ e efluente $\left(\star^{-}\right)$no reator anaeróbio de leito fluidificado. 


\section{LISTA DE TABELAS}

Tabela 2.1 Referências industriais para o reator anaeróbio de leito fluidificado

Tabela 3.1 Composição da água residuária sintética a base de fenol de acordo com Del Nery (1987) para DQO de 1000 mg/L.

Tabela 3.2 Dimensão, densidade e velocidade de mínima fluidificação 54 para as partículas de poliestireno

Tabela 3.3 Parâmetros usados no reator de leito fluidificado

Tabela 3.4 Fases em que a pesquisa foi desenvolvida

Tabela 3.5 Freqüência de coleta e analise de amostras para todas as fases de operação

Tabela 4.1 Resultados obtidos durante os 14 dias de adaptação do 66 inóculo

Tabela 4.2 Resultados médios obtidos e seus respectivos desvios, para cada faixa de concentração de fenol, aplicada no reator preenchido com partículas de poliestireno

Tabela 4.3 Resultados de estudos de degradação anaeróbia de fenol.

Tabela 4.4 Porcentagem média de DQO removida se seus respectivos desvios para cada concentração de fenol aplicada

Tabela 4.5 Valores médios obtidos para alcalinidade a bicarbonato no reator

Tabela 4.6 Valores médios obtidos para ácidos voláteis totais no reator

Tabela 4.7 Ácidos voláteis detectados via cromatografia líquida 90 durante a operação do reator anaeróbio de leito fluidificado 
Tabela 4.8 Valores médios para os parâmetros monitorados durante as fases I a VIII 


\section{LISTA DE SÍMBOLOS E ABREVIAÇÕES}

MEV Microscopia eletrônica de varredura

PCP Pentaclorofenol

PET Polietileno tereftalato

PVC Policloreto de vinila

RALF Reator anaeróbio de leito fluidizado

RAHLF Reator anaeróbio horizontal de leito fluidizado

TDH Tempo de detenção hidráulica

$\mathrm{TDH}_{\mathrm{r}} \quad$ Tempo de detenção hidráulica relativo a altura do leito

TRC Tempo de retenção celular

UASB Reator anaeróbio de manta de lodo

4-AAP 4-amino-antipirina

PEC Polímeros extracelulares

EDX Espectroscopia de dispersão de raio X

FB Filtro biológico

DNA Ácido desoxirribonucléico

$\mathrm{K}_{\mathrm{eq}} \quad$ Constante de equilíbrio aparente

POA Processos oxidativos avançados

NP Nitrofenol

CSTR Continuous stirred tank reactor

ABR Reator anaeróbio em batelada

AMBR Reator anaeróbio em batelada modificado

AP Aminofenol

AME Atividade metanogênica específica 
UOTs Unidades operacionais de taxonomia

FID Detector de ionização de chama

HMDS Hexametildisilazani

$\Phi \quad$ Dimensão da partícula

$\rho \quad$ Densidade da partícula

$\left(\mathrm{ML}^{-3}\right)$

$\mathrm{C}_{\mathrm{f}} \quad$ Concentração de fenol no inóculo

$\left(\mathrm{ML}^{-3}\right)$

DQO Demanda química de oxigênio

$\left(\mathrm{ML}^{-3}\right)$

$\mathrm{H}_{\mathrm{o}} \quad$ Altura correspondente a massa de partículas em leito fixo

$\mathrm{H}_{\mathrm{f}} \quad$ Altura correspondente a massa de partículas em leito fluidizado

M Massa de partículas usada nos reatores

Q $\quad$ Vazão de recirculação

$\left(\mathrm{L}^{3} \mathrm{~T}^{-1}\right)$

V Volume do reator

$\left(\mathrm{L}^{3}\right)$

$\mathrm{V}_{\mathrm{mf}} \quad$ Velocidade de mínima fluidificação

$\left(\mathrm{LT}^{-1}\right)$

SST Sólidos suspensos totais

$\left(\mathrm{ML}^{-3}\right)$

SSV Sólidos em suspensão voláteis

$\left(\mathrm{ML}^{-3}\right)$

SVT Sólidos voláteis totais

$\left(\mathrm{ML}^{-3}\right)$

TCOV Taxa de carregamento orgânico volumétrico

$\left(\mathrm{ML}^{-3} \mathrm{~T}^{-1}\right)$

CvDQO Carga volumétrica de DQO

$\left(\mathrm{ML}^{-3} \mathrm{~T}^{-1}\right)$

AVT Ácidos voláteis totais

AB Alcalinidade a bicarbonato

(ML-3)

Yt DQO Coeficiente de produção de lodo 


\section{CAPÍTULO 1}

\section{INTRODUÇÃO}

As principais fontes pontuais de poluição das águas são os resíduos líquidos industriais e o esgoto municipal. Com os interesses na regulamentação dos lançamentos cada vez mais restritos, torna-se necessário a utilização de sistemas de tratamento econômico, compacto e altamente eficiente (HIRATA et al., 1998).

A produção industrial de produtos químicos orgânicos tóxicos em larga escala e seu uso em várias aplicações tem levado a sérios problemas ambientais. Análises do solo de áreas contaminadas têm mostrado que os compostos tóxicos/recalcitrantes podem, algumas vezes, persistir por um longo período, mesmo na presença de microrganismos que são capazes de mineralizar os contaminantes. Em um biorreator existe um melhor controle do microambiente celular do que no solo e velocidades de degradação mais elevadas podem ser atingidas (HECHT et al., 2000).

Por serem recalcitrantes e causarem toxidade às bactérias, quando presentes em águas residuárias, os compostos aromáticos como fenóis ou fenóis metilados têm um papel importante no decréscimo da remoção da demanda química de oxigênio (DQO) em sistemas de tratamento. A remoção destes componentes, mesmo presentes em pequenas concentrações, é tão importante quanto a redução da fração de DQO (KENNES et al., 1997).

O fenol está presente em efluentes de indústrias de gaseificação de carvão, produção de coque, farmacêutica, pesticidas, fertilizantes, produção de tintas, química sintética e polpa de papel. Fenol em altas concentrações é tóxico a organismos vivos (TAY et al., 2001). No Brasil, os padrões de qualidade de água estabelecem concentrações de fenol de até 0,001 
$\mathrm{mg} / \mathrm{L}$ para uso em locais destinados à balneabilidade e até $1 \mathrm{mg} / \mathrm{L}$ para uso na navegação. Os padrões de emissão correspondem a valores de 0,5 mg/L (CONAMA 357, 2005).

Dentre as alternativas técnicas de tratamento de fenol, os processos biológicos oferecem custos relativamente baixos, quando comparados com os processos físico-químicos (METCALF \& EDDY, 1991). O tratamento de águas residuárias contendo fenol por processos aeróbios já demonstrou ser viável (SILVA, 1995; LEITE, 1997; COSTA, 1999; BERTOLLO, 2001). Estudos de processos anaeróbios também têm sido desenvolvidos, mostrando ser eficientes (KENNES et al., 1997; TAY et al., 2001; BOLAÑOS, 2001; SANCINETTI, 2004; SADER, 2005).

O processo de tratamento anaeróbio de águas residuárias tem vantagens em relação à economia de energia, não há necessidade de oxigênio, baixa produção de biomassa residual e geração de um resíduo com valor, gás metano; embora apresente desvantagens em relação à qualidade do efluente, velocidade de tratamento e inibição biológica (WANG et al., 1986). A desvantagem da baixa velocidade de degradação pode ser melhorada pelo desenvolvimento de novos reatores para aumentar a concentração de biomassa, aumentando as velocidades de degradação, como por exemplo, a utilização de um meio suporte (DENAC \& DUNN, 1988; HANAKI et al., 1997; LETTINGA et al., 1997).

Em um reator anaeróbio de leito fluidificado, os microrganismos crescem formando um filme na superfície das partículas do meio. A alta concentração de biomassa nesse reator e a redução à transferência de massa reduzem o tempo de tratamento, e desta forma, altas cargas de matéria orgânica podem ser empregadas. Nos processos de leito expandido e fluidificado a biomassa cresce em filmes de espessura reduzida, aderida a partículas de tamanho pequeno. A expansão e fluidificação do meio reduzem ou eliminam os problemas de entupimento, além de aumentarem a retenção de biomassa e o contato desta com o substrato, permitindo, como conseqüência, reduções significativas dos tempos de detenção hidráulica nos reatores 
(CHERNICHARO, 1997). Estas características fazem do reator anaeróbio de leito fluidificado uma boa opção para o tratamento de águas residuárias (SREEKRISHNAN et al., 1991).

O tratamento anaeróbio de compostos fenólicos tem sido proposto por vários autores e resultados satisfatórios têm sido obtidos, com alta eficiência de remoção de fenóis (CHENG et al., 1991; COSTA, 1994; FANG et al., 1996; BOLAÑOS, 2001; TAY et al., 2001; FANG et al., 2004; SANCINETTI, 2004; SADER, 2005; VEERESH et al., 2005; FANG, 2006).

Apesar da literatura apresentar diversos estudos relacionados a degradação anaeróbia de fenol, poucas pesquisas abordam sobre o tratamento de águas residuárias contendo elevadas cargas orgânicas de fenol em reator anaeróbio de leito fluidificado. Observou-se nestes estudos que alguns aspectos que influenciavam a degradação do fenol necessitavam ser melhor explorados, como por exemplo: adaptação do inóculo ao fenol no próprio reator, tempo de partida, otimização do tempo de adaptação da biomassa para cada concentração de fenol empregada, verificação da formação de biogás pelo sistema, etc.

Portanto, diante dos resultados apresentados por diversos autores, este estudo propôs a utilização de reator anaeróbio de leito fluidificado submetido ao aumento progressivo da carga orgânica no tratamento de fenol, para explorar destes aspectos. 


\subsection{Objetivos}

Esta pesquisa teve como objetivo geral, analisar a influência do aumento progressivo da carga orgânica na estabilidade e eficiência de remoção de fenol em reator anaeróbio de leito fluidificado utilizando água residuária sintética contendo fenol como única fonte de carbono, utilizando consórcios de microrganismos anaeróbios com potencial de degradar eficientemente fenol e meio suporte que favorece a sua degradação.

Visando uma melhor compreensão do reator, este estudo pretende-se atingir os seguintes objetivos específicos:

a) Realizar a adaptação da biomassa ao fenol no próprio reator;

b) Otimizar o tempo de adaptação da biomassa para cada concentração de fenol empregada;

c) Avaliar o desempenho do reator anaeróbio de leito fluidificado preenchido com partículas de poliestireno na degradação do fenol;

d) Caracterizar morfologicamente os microrganismos presentes nas partículas de poliestireno empregadas como meio suporte no reator anaeróbio de leiro fluidificado;

e) Analisar a produção de biogás durante a operação contínua do sistema. 


\section{CAPÍtULO 2}

\section{REVISÃO BIBLIOGRÁFICA}

\subsection{Generalidades}

A digestão anaeróbia é um dos processos mais antigos utilizados na estabilização de lodos. Envolve a decomposição de matéria orgânica e inorgânica na ausência de oxigênio molecular. As maiores aplicações são na estabilização de lodos concentrados produzidos no tratamento de águas residuárias e no tratamento de alguns resíduos industriais. Nas últimas décadas mostrou-se que resíduos orgânicos diluídos também podem ser tratados anaerobiamente (METCALF \& EDDY, 1991).

Para os reatores anaeróbios serem operados com baixos tempos de detenção hidráulica (TDH) e elevados tempos de retenção celular, os mesmos necessitam incorporar mecanismos de retenção de biomassa, configurando-se assim, os sistemas de alta taxa. Os reatores anaeróbios de alta taxa podem ser classificados em dois grandes grupos, de acordo com o tipo de crescimento de biomassa no sistema, crescimento bacteriano disperso e crescimento bacteriano aderido (CHERNICHARO, 1997).

Os dois processos mais conhecidos para o tratamento anaeróbio com crescimento aderido são os filtros anaeróbios e o processo de leito fluidificado, utilizados para o tratamento de resíduos orgânicos carbonáceos (METCALF \& EDDY, 1991).

O desenvolvimento do processo anaeróbio de leito fluidificado praticamente eliminou os problemas de limitação de difusão de substrato, normalmente inerentes aos processos de leito fixo. No processo de leito fluidificado a biomassa cresce em filmes de espessura muito reduzida, aderidos à partículas de tamanho muito pequeno. A expansão e fluidificação do meio reduzem ou eliminam os problemas de entupimento, além de aumentarem a retenção de 
biomassa e o contato dessa com o substrato, permitindo, como conseqüência, reduções significativas dos TDH nos reatores (CHERNICHARO, 1997).

O reator de leito fluidificado consiste de um vaso cilíndrico contendo um meio suporte inorgânico o qual é fluidificado pela velocidade ascendente do líquido criada pelas taxas de escoamento de alimentação e recirculação. Um separador trifásico no topo do reator garante a eficiência de separação do líquido, biogás e sólido (HOLST et al., 1997).

Os reatores de leito fluidificado oferecem melhor transferência de massa para o biofilme do que os sistemas de leito fixo, não estão sujeitos ao empacotamento da biomassa ou sólidos em suspensão, apresentam melhor estabilidade e melhor eficiência de remoção de DQO, quando comparados com o reator anaeróbio de manta de lodo e fluxo ascendente (UASB), além do menor requisito de área (DENAC \& DUNN, 1988, BUFFIÈRE et al., 1995). O tempo médio de retenção celular atingido em um reator anaeróbio de leito fluidificado é em magnitude maior que os tempos normalmente atingidos em sistemas de tratamento anaeróbio convencionais, tais como os digestores de lodo, tanques sépticos e lagoas anaeróbias (CHEN et al., 1988).

Alguns fatores que contribuem para a eficiência do processo de leito fluidificado incluem (HICKEY \& OWENS, 1981): a) máximo contato entre o líquido e o meio suporte; b) resistência difusional do filme líquido é mínima devido ao movimento da partícula e velocidade do líquido; c) problemas de canais preferenciais, empacotamento e retenção de gás, comumente encontrados em leito fixo, são evitados; d) habilidade de controlar e otimizar a espessura do filme biológico, e) pequenos meios podem ser usados, resultando em altas superfícies específicas para a colonização biológica. 


\subsection{Aspectos Referentes ao Fenol e ao Metabolismo Anaeróbio}

\subsubsection{Fenol}

Fenol e seus derivados são poluentes comumente presentes nos efluentes industriais, como exemplos podem ser citados os efluentes das indústrias de ferro e aço, refinarias de petróleo, pesticidas, solventes e tintas, farmacêuticas, celulose e papel e provenientes de outras variedades de indústrias (ALNAIZY \& AKGERMAN, 2000; ANNADURAI et al., 2002). Também são considerados poluentes orgânicos perigosos e difícieis de serem eliminados, quando presentes em altas concentrações (ARAÑA et al., 2001; GERNJAK et al., 2003).

A ingestão contínua de fenol por um período prolongado em níveis de concentrações entre 10 e $240 \mathrm{mg} / \mathrm{L}$ pode causar dores no trato gastro-intestinal, diarréia, excreção de urina escura e problemas na visão (KUMARAN \& PARUCHI, 1997). A ingestão de 1 g pode ser letal para os seres humanos devido ao seu efeito sobre o sistema nervoso (SANZ et al., 2002). Na corrente sanguínea é letal em concentrações entre 4,7 a 130 mg por 100 mL. Fenóis são tóxicos para várias funções bioquímicas e para a vida aquática acima de $50 \mu \mathrm{g} / \mathrm{L}$ (KUMARAN \& PARUCHURI, 1997; SANZ et al., 2002). A remoção de fenol de água residuária é necessária para a preservar a qualidade do meio ambiente, devido à alta toxicidade, foi utilizado como composto modelo neste trabalho.

Para que um composto seja classificado como fenol, suas moléculas devem ter pelo menos um grupo $\mathrm{OH}$ ligado diretamente ao anel aromático. Os mais comuns são hidroxibenzeno (fenol ou ácido fênico), difenóis, catecóis, cresóis e naftol.

O fenol também é conhecido com ácido carbólico, ácido fênico, ácido fenílico, hidróxido fenil, hidroxibenzeno, oxibenzeno (THE MERCK INDEX, 1996). Em geral são 
sólidos, pouco solúveis em água, cerca de $8 \%$ de solubilidade, de cheiro forte característico. São tóxicos e têm ação cáustica sobre a pele. Apresentam caráter ácido existindo na natureza, na forma de essência, em estruturas complexas.

O fenol é biodegradável tanto aeróbia como anaerobiamente, mas pode ser tóxico aos microrganismos mesmo a concentrações relativamente baixas de $10 \mathrm{mg} / \mathrm{L}$. O fenol pode ser inibidor do crescimento mesmo àquelas espécies que possuem atividade metabólica usando-o como substrato de crescimento. A degradação de fenol a metano e gás carbônico em ambiente anaeróbio ocorre por meio da ação dos microrganismos metabolizadores de fenol, utilizadores de hidrogênio e metanogênicos acetotróficos. A adaptação do lodo é necessária e, geralmente, leva meses. O reator usado no tratamento de água residuária fenólica exibe alta sensibilidade a mudanças nas condições operacionais tais como, carga e temperatura, e a recuperação é gradativa e demorada (TAY et al., 2001).

Apesar do fato dos fenóis estarem presentes na maioria dos solos e sedimentos, somente poucos microrganismos anaeróbios degradadores de fenol foram isolados e caracterizados. Em 1986 ocorreu o primeiro relato de bactéria obrigatoriamente anaeróbia degradadora de fenol relacionada a Desulfobacterium phenolicum (VAN SCHIE \& YOUNG, 1998).

\subsubsection{Compostos Fenólicos}

O fenol (ácido carbólico, ácido fênico) goza da dupla distinção de ter sido usado por Lister, durante os anos de 1860, em seus trabalhos sobre o desenvolvimento das técnicas de cirurgia asséptica, e de ser o padrão contra o qual outros desinfetantes são avaliados em sua ação bactericida. Embora seja ainda popular, muitos outros desinfetantes recentes são muito mais eficazes e ativos em concentrações mais baixas. O fenol e alguns derivados, 
provavelmente atuam primariamente pela desnaturação das proteínas celulares e pelo dano das membranas celulares. Alguns deles, especialmente o hexilresorcinol, reduzem grandemente a tensão superficial, e esta propriedade contribui, indubitavelmente, para sua ação antimicrobiana (PELCZAR et al., 1980).

As substâncias fenólicas podem ser bactericidas ou bacteriostáticas, dependendo da concentração utilizada. Os esporos bacterianos e os vírus são mais resistentes do que as células vegetativas. Alguns compostos fenólicos são altamente fungicidas. Sua atividade antimicrobiana é reduzida em pH alcalino e na presença de material orgânico; as temperaturas baixas e a presença de sabão também diminuem a atividade antimicrobiana (PELCZAR et al., 1980).

O fenol cristalino puro é incolor. As soluções aquosas de 2 a $5 \%$ podem ser utilizadas na desinfecção de materiais e instrumentos ou utensílios contaminados (PELCZAR et al., 1980). Os cresóis são várias vezes mais germicidas do que o fenol; suas três formas diferentes (o-, m- e p-cresol) apresentam atividade bacteriana aproximadamente igual.

Os cresóis têm solubilidade limitada em água, mas formam emulsões fáceis em sabões líquidos e álcalis, preparações em que são indicados para aplicações práticas. Atualmente, esses compostos estão sendo substituídos por outro derivado fenólico, o o-fenilfenol. Como o fenol, os preparados deste composto são indicados para a desinfecção de objetos inanimados (PELCZAR et al., 1980).

Diversas espécies químicas impactantes aos microrganismos podem ser encontradas em águas residuárias industriais podendo atuar como agente bactericida e bacteriostático para a microbiota presente nos corpos receptores ou em sistemas de tratamento. 


\subsubsection{Metabolismo da degradação microbiana de fenóis sob condições anaeróbias}

Neste item, será abordada a degradação microbiana do fenol sob condições anaeróbias (FUCHS et al., 1994), objetivando dar subsídios para o entendimento da degradação anaeróbia do mesmo, visto que o trabalho desenvolvido não teve como objetivo estudar a rota de degradação do fenol.

\subsubsection{Fonte de fenol no ambiente}

Os compostos fenólicos contêm um ou mais grupo hidroxil unido diretamente ao anel aromático. Eles podem também conter outros grupos funcionais como o amino, carboxil, halo, metoxi, nitro, etc. (FEDORAK \& HRUDEY, 1988).

Em nível de partes por bilhão (ppb), os compostos fenólicos causam problemas de gosto e odor as águas de abastecimento e pode ser tóxico aos peixes em águas contaminadas. Em concentrações em partes por milhões (ppm), estes compostos podem ser tóxicos a vida aquática. A toxicidade do fenol para a biota aquática foi estudada por Babich e Davis (1981). Os compostos fenólicos encontrados no ambiente podem ser originados de uma variedade de fontes. As plantas produzem fenóis simples, inclusive o hidroxiquinona, ácido gálico, ácido salicílico e o ácido p-hidroxibenzóico; e muitos fenóis complexos, como os flavonóides; e polímeros de complexos fenólicos, como ligninas, catecol melaninas (HARBORNE, 1980).

O fenol é um composto aromático amplamente utilizado no mundo. Não é apenas um freqüente contaminante ambiental, mas também um intermediário comum no metabolismo anaeróbio de muitos compostos (LONDRY \& FEDORAK, 1992). 


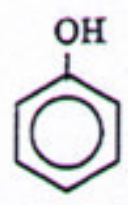

Figura 2.1 - Fórmula estrutural do fenol.

Os fenóis liberados no ambiente de processos industriais são mais preocupantes que os fenóis liberados por plantas por causa da sua alta concentração, potencial toxicidade, e recalcitrância.

\subsubsection{Rotas da biodegradação do fenol}

O fenol, com seu único substituinte hidroxil, é reduzido menos facilmente que são os aromáticos com múltiplos de hidroxilas. A hidroxila substituinte tem um forte efeito indutivo no sistema $\pi$-elétron e assim afeta a simetria e estabilidade da estrutura do anel aromático muito mais que um substituinte metil ou carboxil. Kobayashi et al. (1989) estudaram as rotas propostas para a degradação do fenol sob condições metanogênicas. Foram observadas duas rotas metabólicas principais. Uma é a rota redutiva; a outra é a rota da carboxilação.

\subsubsection{Rota redutiva}

Bakker (1977) demonstrou que o fenol poderia ser degradado por uma cultura mista usando nitrato como o aceptor de elétron terminal. O ácido n-Capróico foi o único intermediário identificado, e foi observado que o anel aromático foi reduzido e produziu ciclohexanona antes do fendimento do anel. Balba e Evans (1980) somaram [U- $\left.{ }^{14} \mathrm{C}\right]$ fenol para um consórcio metanogênico catecol-adaptado. Eles descobriram as classificações 
ciclohexanona, 2-hidroxiciclohexanona, adipato, sucinato, propionato, e acetato nos extratos de cultura. Estes resultados confirmaram a rota redutiva proposta por Bakker (1977). Uma rota para a degradação do fenol, que procede completamente a saturação do anel a ciclohexanol, conversão para ciclohexanona, e a subseqüente divisão do anel foi sugerida e é ilustrada na Figura 2.1a (EVANS, 1977; YOUNG, 1984). Na literatura são achados poucos artigos sobre os intermediários. Diversos pesquisadores acrescentaram ciclohexanol ou ciclohexanona a culturas anaeróbias degradadoras de fenol e não foram detectadas a utilização destes intermediários, provavelmente acumulando-os (BAK \& WIDDEL, 1986; TSCHECH \& FUCHS, 1987; KOBAYASHI et al., 1989; BÉCHARD et al., 1990).

\subsubsection{Rota da carboxilação}

Uma segunda rota de degradação do fenol foi mostrada por Neufeld et al. (1980), baseado no trabalho de Chinielowski et al. (1965). Nesta rota, o fenol é primeiro carboxilado a benzoato antes da redução e divisão do anel aromático (Figura 2.1b). Esta rota será revisada em detalhes desde o uso do consórcio metanogênico. 
a)

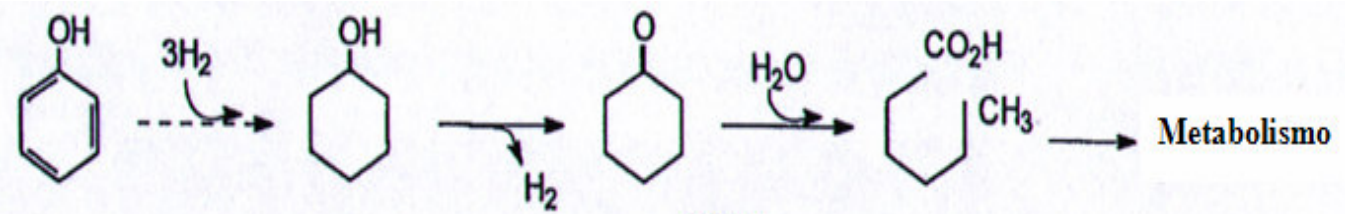

b)<smiles>Oc1ccccc1</smiles><smiles>O=C(O)c1ccc(O)c(C(=O)O[Na])c1</smiles>

(2)

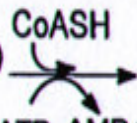<smiles>[GeH3]</smiles>
ATP AMP+PPi<smiles>O=Cc1ccc(O)cc1</smiles><smiles>CC(C)O</smiles>

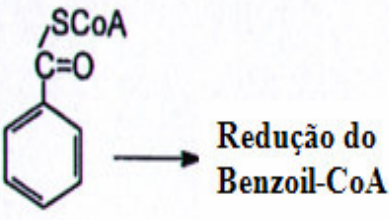

c)

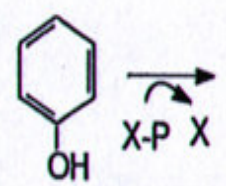<smiles>O=P(O)(O)c1ccccc1</smiles><smiles>CC(C)(C(=O)O)C1CC(O)CCC1C(=O)O</smiles>

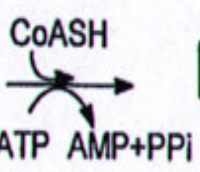<smiles>C1CC[GeH2]C1</smiles>

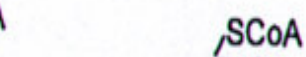

Figura 2.2 - Rotas propostas na degradação anaeróbia do fenol.

a) Rota redutiva (BALBA \& EVANS, 1980); b) Rota da carboxilação (NEUFELD et al., 1980). (1) fenol carboxilase, (2) ligase 4-Hidroxibenzoato-CoA, (3) redutase 4Hidroxibenzoil-CoA, c) Rota da carboxilação das desnitrificantes Pseudomonas sp. K172 (LACK \& FUCHS, 1994).

Diversos estudos indicaram que a degradação do fenol é iniciada através da carboxilação no lugar de inserção de outros grupos hidroxil. Desde que falte fenol um grupo carboxílico, não pode ser ativado através da coenzima $\mathrm{A}$; um pré-requisito que se mostra essencial para a redução completa do anel na rota do benzoato. Alguns pesquisadores descobriram que a carboxilação do fenol foi realizada por bactérias desnitrificantes (TSCHECH \& FUCHS, 1987, 1989) e consórcios metanogênicos (KNOLL \& WINTER, 1987; KOBAYASHI et al., 1989; BISAILLON et al., 1991a; GENTHNER et al., 1991).

Muitas evidências sustentam a carboxilação do fenol. Knoll e Winter (1987) usaram uma atmosfera de $80 \%$ de $\mathrm{H}_{2}$ e $20 \%$ de $\mathrm{CO}_{2}$ para avaliar a estimulação da inibição em um consórcio metanogênico na degradação de fenol. Isto conduziu à acumulação de um 
intermediário que foi identificado como ácido benzóico. O ácido benzóico também foi formado em experiências subseqüentes sob uma atmosfera de $80 \%$ de $\mathrm{N}_{2}$ e $20 \%$ de $\mathrm{CO}_{2}$. Estes resultados indicaram que a rota metabólica usada não era a redutiva. O ácido radioativo benzóico foi detectado quando o fenol sem classificação e ${ }^{14} \mathrm{CO}_{2}$ foram adicionados ao consórcio metanogênico (KNOLL \& WINTER, 1987). Isto mostrou claramente o envolvimento do $\mathrm{CO}_{2}$ no metabolismo do fenol sob condições metanogênicas e é consistente com os resultados do estudo realizado por Fedorak e Hrudey (1988), que colocaram a hipótese que as bactérias degradadoras de fenol em um consórcio metanogênico podem requerer $\mathrm{CO}_{2}$.

Béchard et al. (1990) também enriqueceram um consórcio metanogênico, no qual o ácido benzóico acumulado como fenol desapareceu e o ciclohexanol, ciclohexanona, propionato, butirato, isobutirato, valerato, e isovalerato não foram detectados como intermediários na degradação do fenol. Estes resultados sugeriram que o consórcio usado seguiu a rota da carboxilação para transformar o fenol. 
A.

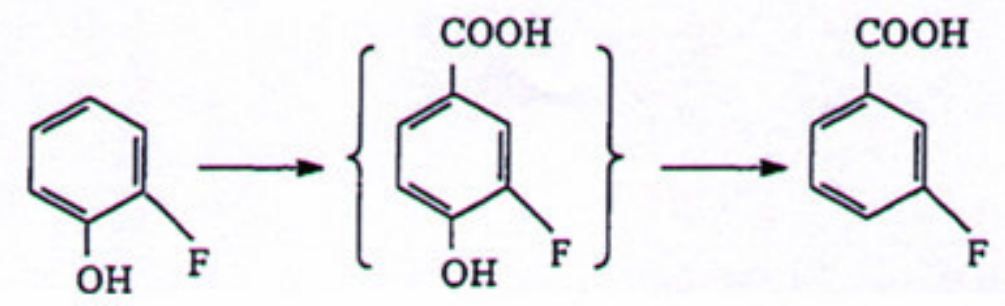

2-Fluorofenol

3-Fluoro-4-hidroxibenzoato

3-Fluorobenzoato

B.

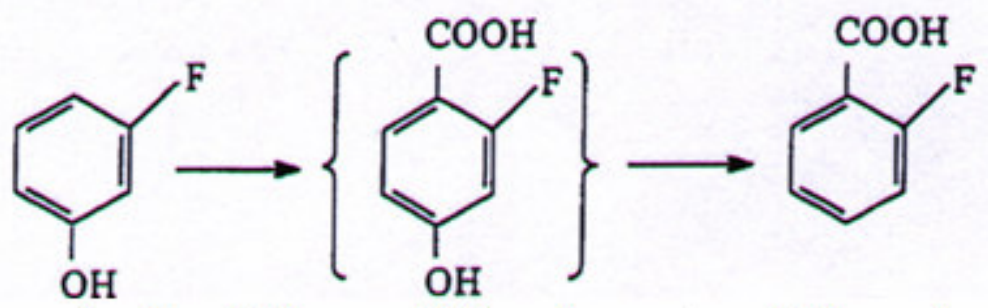

3-Fluorofenol

2-Fluoro-4-hidroxibenzoato

2-Fluorobenzoato

C.<smiles>Oc1ccc(F)cc1</smiles>

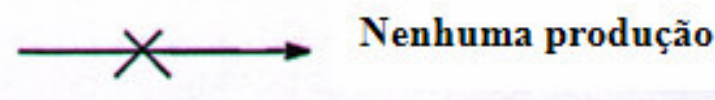

4-Fluorofenol

Figura 2.3 -. Produtos resultantes da transformação de monofluorofenóis a monofluorobenzoatos via para-carboxilação.

Combinações nos parênteses são intermediários que não foram descobertos (GENTHNER et al., 1989).

$\left[1-{ }^{13} \mathrm{C}\right] \mathrm{O}$ fenol foi carboxilado para $\left[4-{ }^{13} \mathrm{C}\right]$ benzoato por uma transformação anaeróbia do fenol utilizando um consórcio enriquecido, o qual não formou 4-hidroxibenzoato como um intermediário livre, mas converteu 4-hidroxibenzoato primeiro a fenol e depois para benzoato (ZHANG et al., 1990). Uma cultura mista definida estritamente anaeróbia que catalisa fenóis deteriorados revelou que a carboxilação foi exclusivamente na posição C-4 (GALLERT et al., 1991). Era esperado que o 4-hidroxibenzoato seja um intermediário para toda fermentação pelas bactérias e que o benzoato não é formado diretamente. A formação do 
benzoato de fenol requereria a carboxilação seguida pela dehidroxilação (KNOLL \& WINTER, 1987; KOBAYASHI et al., 1989; ZHANG et al., 1990; BÉCHARD et al., 1990; GENTHNER et al., 1990; GALLERT et al., 1991; BISAILLON et al., 1991).

Tschech e Fuchs $(1987 ; 1989)$ mostraram a primeira evidência da oxidação do fenol em bactérias desnitrificantes por carboxilação do fenol para 4-hidroxibenzoato. Primeiro, o intermediário hipotético da degradação do fenol, ciclohexanona não foi detectado pelas culturas degradadoras de fenol nem poderiam ser derivado da degradação da ciclohexanona. Segundo, as bactérias desnitrificantes enriquecidas e isoladas sob condições anaeróbias com ciclohexanol ou ciclohexanona não pôde degradar fenol anaerobiamente. Seus experimentos mostraram que a carboxilação do anel aromático é o primeiro passo na degradação do fenol sob condições desnitrificantes. O fenol foi carboxilado a 4-hidroxibenzoato, seguiu através da ativação da coenzima A e dehidroxilação para eliminar o substituinte hidróxi para formar benzoil-CoA (Figura 2.1b). Lack e Fuchs (1992) descobriram que as desnitrificantes Pseudomonas K172 catalisam a carboxilação do fenilfosfato a 4-hidroxibenzoato e fosfato.

Além disso, eles apresentaram a evidência que a fosforilação do fenol para fenilfosfato é o passo para ativar a carboxilação (LACK \& FUCHS, 1994). In vitro a enzima da carboxilação foi inativada com o fenol; somente fenilfosfato foi prontamente carboxilado como indicado na Figura 2.1c.

\subsubsection{Carboxilação e decarboxilação}

A carboxilação do fenol e a decarboxilação do 4-hidroxibenzoato foram mostradas primeiro por Grant e Patel (1969) com a anaeróbia facultativa Klebsiella pneumoniae. Também ocorre com as bactérias desnitrificantes Pseudomonas (TSCHECH \& FUCHS, 1989), uma co-cultura anaeróbia obrigatória degradadora de fenol (Gallert \& Winter, 1992), 
microrganismos redutores de sulfato (LONDRY \& FEDORAK, 1992), e Clostridium (HSU et al., 1990; ZHANG \& WIEGEL, 1994).

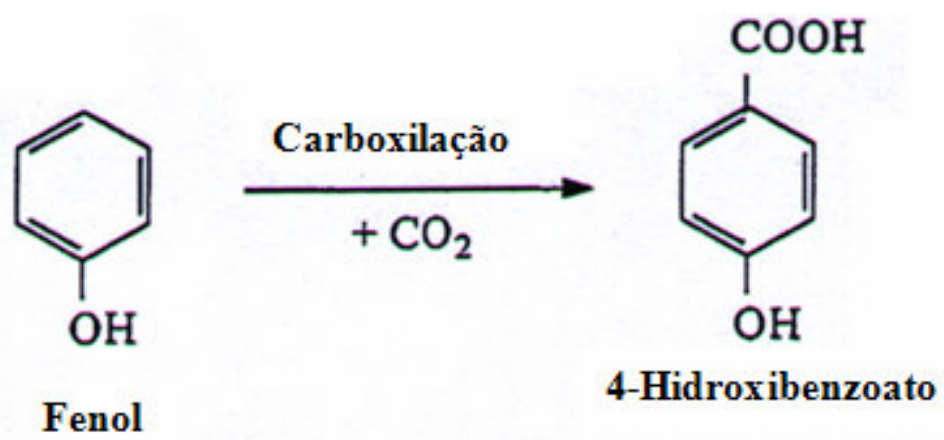

Figura 2.4 - Carboxilação do fenol.

A carboxilação do anel aromático é o primeiro passo na degradação do fenol (TSCHECH \& FUCHS, 1987, 1989; DANGEL et al., 1991), do o-cresol e possivelmente de outros compostos fenólicos substituídos na orto-posição (BISAILION et al., 1991b; RUDOLPHI et al., 1991). Também o $m$-cresol pode ser carboxilados por alguns microrganismos (ROBERTS et al., 1990; RAMANAND \& SUFLITA, 1991). Algumas pesquisas foram realizadas estudando a carboxilação do fenol por bactérias desnitrificantes (TSCHECH \& FUCHS, 1987, 1989; LACK et al., 1991; LACK \& FUCHS, 1992), por bactérias redutoras de sulfato (BAK \& WIDDEL, 1986), e consórcios fenol-degradantes (GENTHNER et al., 1991; BISAILION et al., 1991a; GALLERT \& YOUNG, 1992). 


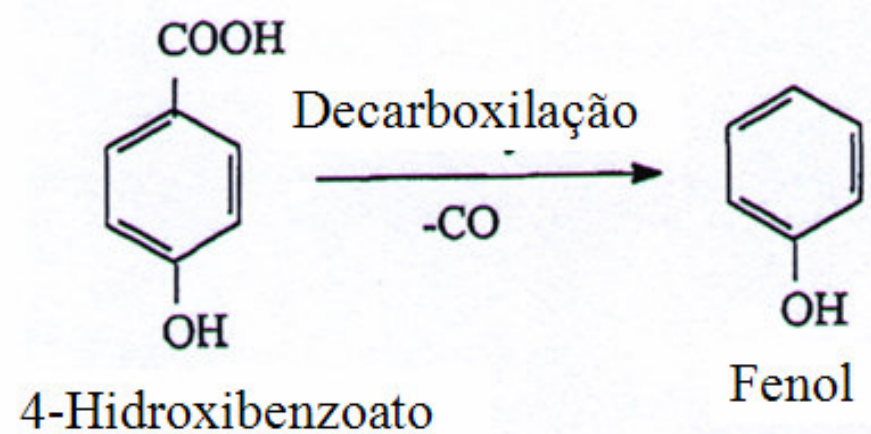

Figura 2.5 - Decarboxilação do fenol.

A decarboxilação de ácidos aromáticos é comum em transformações que não fazem parte de uma rota de degradação. Existem vários artigos na literatura mostrando a decarboxilação do 4-hidroxibenzoato para fenol (GALLERT \& WINTER, 1992, 1994; ZHANG \& WIEGEL, 1994; HE \& WIEGEL, 1995). Hus et al. (1990) mostraram que o aromático-dependente decarboxilase possui um papel importante na cadeia alimentícia desde que eles removem ácidos orgânicos ou produzam $\mathrm{CO}_{2}$ para a acetogênese. Em geral, a decarboxilação de ácidos aromáticos com a função hidroxil para do grupo carboxil é uma reação quimicamente favorável e foi observado em sistemas biológicos.

\subsubsection{Sob condições metanogênicas}

Quando o fenol é degradado, o 4-hidroxibenzoato é difícil de se detectar. O intermediário hidroxibenzoato não foi observado antes de Knoll e Winter $(1987,1989)$ porque a dehidroxilação redutiva do 4-hidroxibenzoato acontece imediatamente no seu consórcio misto (Figura 2.3). A medida direta da carboxilação do fenol para 4-hidroxibenzoato foi impossível devido a uma atividade muito ativa de decarboxilação reversível em extratos de células livres. Isto foi provado usando análise de espectrometria de massa do benzoato formado da degradação do fenol e ${ }^{14} \mathrm{CO}_{2}$ teste (GALLERT et al., 1991). 
Genthner et al. (1991) descobriram que o 4-hidroxibenzoato foi detectado no seu consórcio fenol-degradante usando uma estrutura análoga de 4-hidroxibenzoato ou elevadas concentrações iniciais de fenol ou benzoato. Este consórcio fenol-degradante transformou o 4hidroxibenzoato completamente a fenol por decarboxilação. Eles também descobriram que a decarboxilação foi mais rápida que a carboxilação nos seus consórcios metanogênicos.

Zhang e Wiegel (1994) mostraram que a decarboxilação do 4-hidroxibenzoato e 3,4dihidroxibenzoato são reações reversíveis em células inteiras em suspensões e em seus extratos de células C. hydroxybenzoicum. Além disso, a constante de equilíbrio aparente para as reações 4-hidroxibenzoato ${ }^{-}+\mathrm{H}_{2} \mathrm{O}=$ fenol $+\mathrm{HCO}_{3}^{-}$e 3,4-dehidroxibenzoato ${ }^{-}+\mathrm{H}_{2} \mathrm{O}=$ catecol $+\mathrm{HCO}_{3}{ }^{-}$foi determinado sendo $\mathrm{K}_{\mathrm{eq}}=11,4$ e 5,05, respectivamente. Estes valores indicam que a formação do produto da decarboxilação seria fortemente favorecido. Isto poderia explicar porque nenhuma ou alguma quantidade traço de 4-hidroxibenzoato foi detectada nas culturas enriquecidas que degradam fenol suplementadas com baixas concentrações de fenol. Geralmente, as atividades reversíveis da carboxilação do fenol e da decarboxilação do 4-hidroxibenzoato foram universalmente descobertas sob condições metanogênicas (KNOLL \& WINTER, 1989; BÉCHARD et al., 1990; GENTHNER et al., 1990; BISAILLON et al., 1991a; LONDRY \& FEDORAK, 1993).

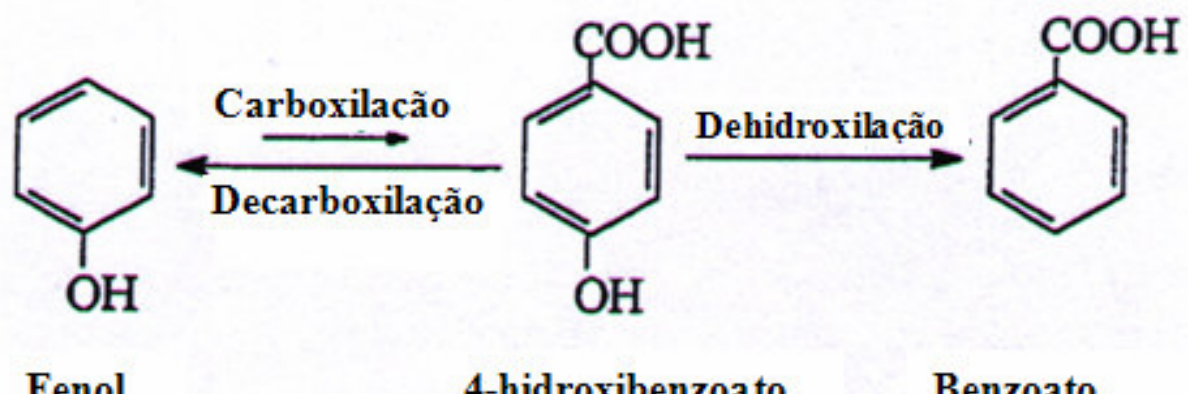

Figura 2.6 - Transformação do fenol para benzoato via 4-hidroxibenzoato sob condições metanogênicas. 


\subsection{Aspectos referentes ao reator anaeróbio de leito fluidificado}

\subsubsection{Reator anaeróbio de leito fluidificado}

Devido à necessidade da operação dos reatores anaeróbios com baixos tempos de detenção hidráulica (TDH) e elevados tempos de retenção celular foram desenvolvidos sistemas que incorporaram mecanismos de retenção de biomassa, denominados sistemas de alta taxa. Os reatores anaeróbios de alta taxa podem ser classificados em dois grandes grupos, de acordo com o tipo de crescimento de biomassa no sistema, crescimento microbiano disperso e crescimento microbiano aderido (CHERNICHARO, 1997).

O reator anaeróbio de leito fluidificado aplicado ao tratamento anaeróbio de águas residuárias foi desenvolvido por Jewell e colaboradores nos anos 70, visando o aumento de retenção de grande quantidade de biomassa e, ao mesmo tempo, eliminando problemas de colmatação ocasionados pelo acúmulo de materiais sólidos nos interstícios, como ocorre em reatores de leito fixo (CAMPOS \& PEREIRA, 1999).

O primeiro reator industrial foi construído em 1986 para o tratamento de água residuária de cervejaria. Desde então, diversos reatores industriais já foram desenvolvidos como pode ser observado na Tabela 2.1 (HOLST et al., 1997).

O reator de leito fluidificado consiste de um vaso cilíndrico contendo meio suporte inorgânico o qual é fluidificado pela velocidade ascendente do líquido criada pelas taxas de escoamento de alimentação e recirculação. Um separador no topo do reator garante a eficiência de separação do líquido, biogás e sólido.

Alguns fatores que contribuem para a eficiência do processo de leito fluidificado incluem (HICKEY \& OWENS, 1981; DENAC \& DUNN, 1988; BUFFIÈRE et al., 1995): 
a) máximo contato entre o líquido e o meio suporte;

b) resistência difusional do filme líquido é mínima devido ao movimento da partícula e velocidade do líquido;

c) problemas de canais preferenciais, empacotamento e retenção de gás, comumente encontrados em leito fixo, são evitados;

d) habilidade de controlar e otimizar a espessura do filme biológico;

e) pequenos meios podem ser usados, resultando em superfícies altamente específicas para a colonização biológica;

f) melhor estabilidade e melhor eficiência de remoção de DQO, quando comparado com o reator anaeróbio de manta de lodo (UASB);

g) menor requisito de área;

h) pode ser operado sobre uma grande faixa de concentração orgânica e as taxas de degradação são proporcionais à concentração do efluente. 
Tabela 2.1 - Referências industriais para o reator anaeróbio de leito fluidificado.

Fonte: Holst et al. (1997).

\begin{tabular}{|c|c|c|c|c|}
\hline Indústria & Ano de Partida & $\mathrm{N}^{\mathrm{o}}$ unidades & Diâmetro (m) & Carga (kgDQO/d) \\
\hline Cervejaria & 1986 & 1 & 2,4 & 670 \\
\hline Cervejaria & 1987 & 5 & 5,0 & 50000 \\
\hline Polpa e papel & 1988 & 1 & 4,0 & 6000 \\
\hline Suco de uva & 1988 & 1 & 5,0 & 4600 \\
\hline Amido & 1989 & 2 & 5,0 & 13000 \\
\hline Bebidas leves & 1990 & 1 & 4,5 & 6000 \\
\hline Leite/soro & 1992 & 2 & 5,0 & 13000 \\
\hline Cervejaria & 1993 & 2 & 4,5 & 7500 \\
\hline Amido & 1993 & 1 & 6,0 & 12000 \\
\hline Polpa e papel & 1994 & 1 & 4,5 & 3600 \\
\hline Chocolate & 1995 & 1 & 4,5 & 4300 \\
\hline Ácido cítrico & 1995 & 2 & 4,0 & 7200 \\
\hline Polpa e papel & 1995 & 2 & 4,5 & 6600 \\
\hline Aromas & 1996 & 1 & 3,2 & 2600 \\
\hline Preservantes/geléia & 1996 & 1 & 4,5 & 4800 \\
\hline Comida enlatada & 1996 & 1 & 4,5 & 7000 \\
\hline Milho & 1996 & 1 & 6,1 & 22000 \\
\hline
\end{tabular}

Para atingir elevadas velocidades ascencionais em reator com operação contínua, métodos de retenção celular são necessários para se prevenir a perda de células. As técnicas mais comuns são a imobilização dos microrganismos em suporte apropriado e o uso de membranas de filtração. A filtração em membranas não é muito utilizada em processos industriais (HECHT et al., 2000). 
Independente do sistema de reator considerado, em todos os casos a imobilização do consórcio microbiano anaeróbio específico balanceado é a chave para o sucesso. As razões estão listadas a seguir (LETTINGA et al., 1997):

a) pode-se alcançar alto tempo de retenção do lodo, com custos relativamente baixos;

b) como resultado da predominância do consórcio bacteriano sintrófico balanceado com a biomassa imobilizada, a concentração de intermediários inibidores específicos pode ser mantida em um nível suficientemente baixo, a menos que o sistema esteja sobrecarregado ou exposto a condições ambientais detrimentais;

c) a cinética do processo de degradação é aumentada significativamente como resultado da presença do consórcio bacteriano balanceado imobilizado nos agregados, providenciando que eles não cresçam muito densos;

d) a imobilização da biomassa disponível é fator importante para a susceptibilidade à temperatura, por exemplo, do lodo termofílico.

Em um reator anaeróbio de leito fluidificado o filme microbiano é retido por meio da adesão natural dos microrganismos às partículas de suportes sólidos. Uma vez que o desempenho do processo é dependente da população microbiana presente no sistema, é fundamental conhecer a influência de parâmetros operacionais, fatores físico-químicos e diferentes propriedades do meio suporte (densidade, rugosidade, porosidade) no processo de formação do biofilme (HIDALGO \& GARCÍA-ENCINA, 2002). 


\subsubsection{Desenvolvimento de biofilmes}

A quantidade de biomassa em um reator de leito fluidificado, como em qualquer sistema biológico é um parâmetro fundamental afetando o desempenho do reator. Entretanto, ao contrário de um sistema de crescimento suspenso, não somente a velocidade das reações bioquímicas é influenciada pela quantidade de microrganismos, mas também as características físicas do sistema. Em geral, a biomassa não está uniformemente distribuída no reator e as variações locais da velocidade de reação e de outras características podem ser significativas.

Um biofilme resulta a fixação de microrganismos ao meio ambiente. Os microrganismos aderem firmemente, e frequentemente com especificidade, a quase toda superfície submersa em um ambiente aquoso. Os microrganismos fixam-se por meio de uma matriz de polímeros, principalmente polissacarídeos, que se estende da superfície celular e formam uma massa emaranhada de fibras, denominada de "glicocálise" (SILVA, 1995). As células crescem e reproduzem-se na superfície do meio suporte aumentando a biomassa e o material associado.

O processo de formação de biofilme na superfície do suporte é iniciado por células suspensas presentes no líquido que ficam adsorvidas na superfície e depois crescem como biofilme, utilizando substratos da fase líquida. Como as células suspensas iniciam o processo de formação do biofilme, o número de células suspensas tem efeito na formação do mesmo, além de contribuir para a produção de metano. A natureza do leito em termos de espessura do biofilme e distribuição de partículas depende da qualidade do inóculo usado durante a partida. A presença de altas concentrações de arquéias metanogênicas leva a um grande número de partículas ser colonizada com formação de biofilme (SREEKRISHNAN et al., 1991).

Costerton et al. (1997), utilizando técnicas de microscopia cofocal a laser de varredura, examinaram culturas puras em laboratórios e biofilmes retirados de ambientes 
naturais que possuíam grande diversidade de espécies. Eles constaram que a maioria dos biofilmes é composta de microcolônias de células envolvidas em matrizes de polímeros extracelulares (PEC) entremeadas por canais ("water channels"). Estes canais são formados pelas forças de cisalhamento exercidas pelos fluidos que atravessam o biofilme.

A partida e operação de um reator de leito fluidizado requerem a formação rápida de filme balanceado, estável e com alta densidade na superfície da partícula. Isto significa, no caso anaeróbio, a presença de microrganismos acidogênicos, acetogênicos e metanogênicos, que irão quebrar os complexos orgânicos e convertê-los em metano e gás carbônico. Os principais fatores que afetam a formação do biofilme são: taxa de diluição, carga de DQO, quantidade de inóculo (quantidade de SSV) e qualidade do inóculo (distribuição populacional de diferentes espécies em células suspensas) (SREEKRISHNAN et al., 1991).

Costerton et al. (1995), depois de uma grande série de análises quantitativas de biofilmes em vários ambientes, construíram uma base de dados que lhes permitiu prever a formação de biofilme em sistemas aquáticos, baseado nos seguintes princípios:

a) os microrganismos apresentam notável avidez por aderirem a superfícies;

b) o grau de agregação do biofilme a superfícies em qualquer sistema aquático é controlado pela quantidade de nutrientes disponíveis para a reprodução das células e para a produção de polissacarídeos extracelulares;

c) em ambientes extremamente oligotróficos, nutrientes orgânicos tendem a se associar às superfícies disponíveis, iniciando o desenvolvimento do biofilme, no entanto, os microrganismos geralmente não se aderem a superfícies em ecossistemas onde haja grande deficiência de nutrientes. 
Usando estes princípios, pode-se prever se o biofilme irá se desenvolver em um determinado sistema. Além disso, pode-se verificar a acuidade dessas predições através de observações diretas dos sistemas estudados, dentro dos quais outros fatores locais podem ser igualmente importantes.

Segundo a revisão apresentada por Nicolella et al. (2000), o biofilme pode ser definido como estrutura complexa coerente de células e produtos celulares como polímeros extracelulares, os quais formam grânulos largos e densos espontaneamente, ou crescem aderidos a superfícies estáticas sólidas (biofilmes estáticos) ou em suportes suspensos (biofilmes em partículas suportadas).

Os agregados microbiológicos (tanto na forma de biofilmes, grânulos ou flocos) e o meio de cultura constituem duas fases distintas. Esta característica tem três maiores conseqüências:

a) A retenção de biomassa pode ser usada para melhorar a capacidade de conversão volumétrica do reator quando a conversão está limitada pela quantidade de biomassa presente;

Se nenhuma retenção de biomassa é aplicada, a concentração de biomassa depende somente da concentração de substrato na alimentação, e conseqüentemente grandes tempos de retenção são necessários na presença de alimentações diluídas. Dependendo das características de sedimentação dos agregados, a biomassa pode ser rapidamente separada (por sedimentação) do meio líquido e retida no biorreator. Neste sentido, grânulos e biofilmes suportados em partículas tem vantagem extra, pois podem ser separados mais facilmente do que os flocos (ou seja, é possível uma maior concentração de biomassa) e têm maior área superficial específica (ou seja, maior área de transferência de massa do que biofilmes estáticos). 
b) O substrato precisa atravessar a interface agregado-líquido e ser transportado através do agregado para atingir as células microbianas e ser consumido;

Este transporte ocorre em geral por difusão e resulta em gradiente de concentração dentro do agregado. A profundidade da penetração do substrato em biofilmes depende principalmente da porosidade do biofilme, concentração de substrato no meio líquido, transferência de massa na interface líquido-biofilme e taxa de reação no biofilme.

c) Devido aos gradientes de concentração de substrato difusionais, também existe um gradiente da taxa de crescimento dentro do agregado;

Em sistemas de biofilmes multi-espécies isto levará a um biofilme com estrutura em camadas, onde os microrganismos com a mais alta taxa de crescimento serão encontrados na parte exterior do biofilme, enquanto organismos mais lentos serão encontrados no interior. Como resultado desta organização, organismos com lenta taxa de crescimento serão protegidos das forças cisalhantes externas, e menos perdidos devido ao desprendimento e arraste. Neste caso não somente a taxa de crescimento absoluto máxima deve ser considerada, mas a taxa máxima de crescimento sob as condições no reator (na presença de inibidor).

O grau no qual estas características são relevantes para um sistema específico depende, entre outros fatores, das propriedades físicas e estruturais (densidade, tamanho, porosidade, velocidade de sedimentação, etc.) dos agregados. As propriedades físicas e estruturais de biofilmes suportados em partículas e grânulos são similares, e também suas características hidrodinâmicas, transferência de massa e reação. Deste modo biofilmes suportados em partículas e grânulos podem ser considerados uma categoria única, biofilmes particulados.

A superfície de materiais inertes é o local utilizado preferencialmente pelos microrganismos no desenvolvimento de suas atividades metabólicas. Este fato foi comprovado em diversos estudos, os quais observaram que numa população de microrganismos, aqueles que estavam aderidos apresentaram maior atividade metabólica aos 
que permaneciam em suspensão (VAN LOOSDRECHT et al., 1987). Outra característica importante, é que a aderência dos microrganismos é freqüentemente maior durante a fase de crescimento exponencial, presumidamente como resultado do aumento da hidrofobicidade da parede celular nesta fase.

Segundo van Loosdrecht et al. (1990), a colonização por microrganismos na interface sólido-líquido pode ocorrer como na seqüência descrita:

a) Transporte Difusivo: os microrganismos, quando em suspensão, possuem movimento Browniano devido aos choques entre eles que os possibilita ultrapassar a camada difusiva (camada limite ou filme estagnado) junto à superfície. O transporte difusivo é pequeno se comparado ao convectivo ou ao devido à mobilidade dos microrganismos.

b) Transporte Convectivo: este tipo de transporte de células se dá através do movimento do líquido que circunda os microrganismos e pode ser várias ordens de magnitude maior que o transporte difusivo, no entanto, em regiões próximas à superfície (camada difusiva) a difusão controla o processo.

c) Movimento Ativo: uma vez que o microrganismo esteja nas proximidades de uma superfície, ele pode se dirigir aleatoriamente até ela, ou então, ele pode se aproximar da superfície respondendo quimicamente ao gradiente de concentração de nutrientes que pode existir na região de interface.

A próxima etapa é a aderência inicial, a qual é preponderantemente um processo físico-químico, que pode ser reversível ou irreversível. A diferença não é muito clara. Assim, para facilitar a compreensão do fenômeno, define-se a aderência reversível como sendo a deposição de microrganismos sob uma superfície onde estes ainda apresentem movimento Browniano e possam ser prontamente removidos por tensões de cisalhamento fracas ou pela 
mobilidade dos próprios microrganismos. Já na aderência irreversível, os microrganismos não apresentam movimento Browniano e não podem ser removidos ao menos que fortes tensões de cisalhamento estejam presentes.

Logo após a aderência inicial vem a etapa de fixação à superfície. Depois que o microrganismo está aderido na superfície, estruturas especiais da membrana celular (fibrilase/ou polímeros) formam fortes ligações entre a membrana e a superfície do sólido fixando o microrganismo.

A última etapa é a colonização da superfície. Uma vez fixadas, as células começam a se multiplicar, promovendo o crescimento da biomassa, onde as novas células permanecem aderidas umas as outras, formando o biofilme.

Um uso extenso dos biofilmes é feito no campo da biotecnologia ambiental por três razões principais:

a) comparados com a maioria dos outros bioprocessos industriais, grandes volumes de soluções aquosas diluídas precisam ser tratados;

b) são usadas populações mistas de microrganismos, naturais, as quais formam biofilmes rapidamente;

c) o processo pode ser operado com alta concentração de biomassa no reator, sem a necessidade de sedimentadores para retenção de biomassa e recirculação. Um passo de polimento do efluente geralmente é necessário para remover biomassa suspensa remanescente (desprendida).

De uma forma geral, a colonização das superfícies depende de alguns mecanismos específicos: a interação entre os microrganismos e o meio suporte, as condições ambientais e a disponibilidade de nutrientes. 
Para melhor entender os processos de formação e desenvolvimento dos biofilmes ao longo da operação dos sistemas, é necessária a realização de acompanhamentos e análises das biopartículas. Entre as alternativas disponíveis, os métodos de análise microscópica é uma ferramenta importante para examinar localmente a adesão bacteriana, a formação e o desenvolvimento do biofilme sobre as partículas. As análises mais freqüentes são realizadas através de microscopia ótica e microscopia eletrônica de varredura (MEV). Para a determinação da composição química do biofilme formado, análises de espectroscopia de dispersão de raio $\mathrm{X}(\mathrm{EDX})$, de concentração de polissacarídeos e proteínas aderidos ao biofilme e em suspensão no meio são usualmente realizadas.

Diante disso, o acompanhamento e a análise destes parâmetros são de fundamental importância para uma melhor compreensão dos processos de formação, desenvolvimento e caracterização morfológica dos biofilmes em reatores anaeróbios de leito fluidificado.

Pesquisas acerca da composição e estrutura do biofilme em reatores anaeróbios de leito fluidificado (ARAÚJO, 1995; TERÁN, 1995), têm mostrado que além da presença de bactérias dos gêneros Methanotrix, Methanosarcina, Methanospirilum e Methanococcus, é muito grande a participação porcentual de polímeros extracelulares.

Os tipos de partículas suporte mais frequentemente utilizados em reatores de leito fluidificado são a areia e o carvão ativado. A areia é um material barato e insensível à abrasão. O carvão ativado, por outro lado, necessita de cuidados com relação à abrasão, pois dependendo da turbulência do sistema, pode facilmente haver redução de dimensão. Mais recentemente, materiais poliméricos como nylon, poliestireno, etc., tem sido utilizados como partículas suporte nesses reatores (CAMPOS \& PEREIRA, 1999).

Lin e Lee (2001) desenvolveram um modelo matemático para descrever a degradação de fenol com redução de sulfato em processo anaeróbio com biofilme. O modelo incorporou os mecanismos de transferência de massa difuso e cinética de Monod. Um reator 
de coluna foi empregado para verificar o modelo. Os testes cinéticos em batelada foram conduzidos independentemente para determinar nove coeficientes biocinéticos usados no modelo. As perdas por cisalhamento e a espessura inicial do biofilme foram consideradas a fim de que o modelo simulasse os resultados de concentração de substrato muito bem. As eficiências de remoção de fenol e sulfato foram de 98 e $88 \%$, respectivamente. No estado estacionário, os dados experimentais para a concentração de fenol e sulfato foram maiores do que os obtidos pelo modelo. Isto foi devido ao efeito da perda por cisalhamento tornar mais significativa quando o biofilme crescia mais espesso. A alta perda por cisalhamento aumentou a concentração de substrato efluente. Os autores concluíram que o modelo foi capaz de predizer o desempenho do reator para experimento em estado não-estacionário de utilização de fenol com redução de sulfato e formação de acetato.

\subsubsection{Formação de biofilme na partida e operação de reatores de leito fluidificado}

O tipo e a forma da partícula suporte, utilizada para a adesão dos microrganismos, pode melhorar o desempenho do reator e diminuir o fenômeno de inibição (KINDZIERSKI et al., 1992). O desenvolvimento e manutenção do biofilme formado nesses reatores é importante para garantir alta eficiência e produção de metano no sistema de tratamento. Entretanto, a formação do biofilme depende das características das bactérias, da vazão afluente e das características do meio suporte (KURODA et al., 1988).

Segundo Kindzierski et al. (1992), para avaliar os benefícios do material suporte biológico é necessário considerar parâmetros que influenciam na interação meio suporte microrganismo. As características que influenciam na adesão inicial e aderência dos microrganismos no meio suporte incluem: área e aspereza superficiais, volume dos poros, 
energia livre e carga. Além disso são importantes: $\mathrm{pH}$, concentração do eletrólito, fatores hidrodinâmicos do meio líquido e a carga superficial dos microrganismos.

Contudo, alguns autores têm expressado que o alcance e a especificidade da adsorção das bactérias, sobre superfícies sólidas, são mais fortemente influenciados pelas espécies de bactérias adsorvidas. Pode-se citar as espécies Gram-positivas que aderem mais fortemente a muitos materiais do que espécies Gram-negativas. Muitas bactérias suportam carga negativa no meio líquido e como muitas superfícies estão também carregadas negativamente, diversas forças de repulsão podem tornar-se importantes no processo inicial de adesão de bactérias à superfície (KINDZIERSKI et al., 1992).

Verrier et al. (1987) observaram que o comportamento de aderência inicial de bactérias metanogênicas sobre superfícies poliméricas de diferentes hidrofobicidades pode ser explicada pela carga líquida superficial das bactérias metanogênicas.

Sreekrishnan et al. (1991) estudaram os efeitos da taxa de diluição, carga de DQO, quantidade e qualidade de inóculo na formação do biofilme e desempenho do reator anaeróbio de leito fluidificado. O monitoramento foi feito através da observação microscópica do filme e da superfície, através da produção de ácido e metano e da taxa de redução de DQO. A alimentação consistiu de uma solução de glicose, extrato de levedura e nutrientes com uma DQO de $11000 \mathrm{mg} / \mathrm{L}$. No estudo dos efeitos da taxa de diluição os autores observaram que houve a formação do biofilme quando altas taxas de diluição foram empregadas. A natureza do leito em termos de espessura do biofilme e distribuição das partículas dependeu da qualidade do inóculo usado durante a partida. A presença de altas concentrações de metanogênicas no inóculo aumentou a capacidade de remoção de DQO aumentando a taxa de produção de metano e a formação do biofilme. A produção de metano por unidade de DQO removida apresentou um decréscimo gradativo com o aumento dos níveis de DQO no reator. 
Isto foi devido ao acúmulo de ácidos graxos voláteis que resultou na inibição das metanogênicas. Não foi observada formação de biofilme para altas cargas de DQO.

González et al. (1992) estudaram o desenvolvimento de biofilmes em folha de polietileno e partículas, usando uma mistura de ácido acético, propiônico e butírico como substrato. Os resultados demonstraram uma imobilização preferencial dos microrganismos acetogênicos (fermentam compostos com um ou mais carbonos a ácido acético) na região central da superfície, e colonização dos microrganismos "butirotróficos" nas extremidades.

Hanaki et al. (1994), realizando experimentos em reatores do tipo batelada, observaram que as células imobilizadas toleraram maiores concentrações de fenol que as células não imobilizadas e que nenhuma inibição importante aconteceu quando foram adicionados $1500 \mathrm{mg} / \mathrm{L}$ de fenol.

Buffiere et al. (1998) estudaram a cinética das biopartículas na fermentação da glicose em reator anaeróbio de leito fluidificado. Notou-se uma estratificação ao longo do reator, observando-se a diferença na formação do biofilme ao longo do leito. Nos lugares onde o filme era mais espesso havia maior atividade metanogênica e onde o biofilme era mais fino havia maior atividade acetogênica. Neste estudo o reator utilizado tinha uma altura de 1,5 m e 0,115 m de diâmetro com volume ocupado de 15 L. O material suporte usado foi rocha vulcânica com densidade de $1990 \mathrm{~kg} / \mathrm{m}^{3}$. Simulações e resultados experimentais indicaram que a espessura do biofilme formado influencia na sua composição. Biofilmes espessos dificultam a difusão de substrato, limitando a atividade dos microrganismos acetogênicos, o que explica a predominância de metanogênicos neste tipo de biofilme.

Mendonça (1999) estudou a caracterização do material suporte e a partida de um reator anaeróbio de leito expandido com volume de $32 \mathrm{~m}^{3}$, tratando esgoto sanitário. Para caracterização do material suporte, o autor estudou partículas de poliamida, de polibutireno tereftalato e de carvão ativado granular. Os ensaios realizados durante a caracterização dos 
suportes demonstrou que entre os três tipos de partículas, o carvão ativado granular foi o material mais adequado para compor o leito do reator, por ter apresentado melhor capacidade de aderência dos microrganismos, bem como menor possibilidade de arraste quando empregada elevadas velocidades ascensionais.

A operação do reator foi realizada durante 240 dias, sendo efetuada sem a adição de qualquer tipo de inóculo, e tendo como estratégia o estudo do eventual incremento da carga orgânica e diminuição do tempo de detenção hidráulico. A partida do reator se completou entre o $139^{\circ}$ e $148^{\circ}$ dia de operação, pois nesse período as porcentagens de remoção da DQO se situaram na faixa de $67 \%$ a $71 \%$, para taxa de carregamento orgânico acima de $5,50 \mathrm{Kg}$ $\mathrm{DQO} / \mathrm{m}^{3} \cdot$ dia.

Martinelli (2003) utilizou três reatores anaeróbios de leito fluidificado para estudar a formação e desenvolvimento de biofilme em três materiais suportes, PET (2,2 mm), PVC (2,2 $\mathrm{mm}$ ) e poliestireno $(2,2 \mathrm{~mm})$, durante a degradação de fenol. Lodo proveniente de resíduo de suinocultura previamente adaptado ao fenol foi utilizado como inóculo e a concentração inicial de fenol nos três reatores foi de $100 \mathrm{mg} / \mathrm{L}$. Antes de serem colocadas no reator, as partículas de suporte foram ativadas por contato com solução sulfocrômica e ácido nítrico concentrado conforme metodologia sugerida por Tavares (1992), objetivando favorecer a adesão microbiana. Todas as partículas apresentaram desempenho satisfatório e com 20 dias de operação dos reatores foi possível visualizar colonização em estágio avançado. O melhor resultado foi obtido para o reator com poliestireno como material suporte. A remoção de fenol mostrou-se estável e a concentração foi aumentada para $200 \mathrm{mg} / \mathrm{L}$ e após 8 dias a remoção de fenol foi de $100 \%$. Os reatores com PET e PVC apresentaram problemas no ajuste da vazão de alimentação o que pode ter contribuído para baixa eficiência de remoção de fenol observada. 
Sancinetti (2004) estudando reator anaeróbio de leito fluidizado preenchido com partículas de poliestireno como material suporte, observou que a degradação da água residuária sintética contendo fenol apresentou eficiência de $95 \%$ de remoção de fenol para concentrações de até $500 \mathrm{mg} / \mathrm{L}$, mesmo tendo apresentado algumas instabilidades durante a operação do sistema. As observações em microscópio de varredura (MEV) mostraram boa adesão microbiana e a visualização em microscópio ótico indicou a presença de bacilos retos, ovalados, víbrios, espiralados e cocos, além da presença de morfologias semelhantes a Methanosaeta sp. em todas as fases de operação do reator. Neste estudo não foi feita uma análise quantitativa do biofilme.

Sader (2005) estudou a formação de biofilmes em partículas poliméricas usadas como meio suporte em reatores anaeróbios de leito fluidizado. Foram testados 3 suportes poliméricos: poliestireno, PET e PVC, os quais sofreram tratamento ácido adequado, de modo a proporcionar-lhes características superficiais como rugosidade, porosidade e carga elétrica favorável, com a finalidade de favorecer a adesão microbiana. Os reatores foram inoculados com lodo proveniente de reator UASB que tratava resíduo de suinocultura, adaptado à degradação do fenol por 150 dias. O volume dos reatores era de $770 \mathrm{~cm}^{3}$, e operaram com velocidade ascensional igual a 1,3 vez da velocidade de mínima de fluidificação. A concentração de fenol variou de 100 a 400 mg/L na alimentação de cada sistema, apresentando resultados de remoção de fenol de 97\%, 98\% e 97,5\% e remoção de DQO de $84 \%, 88,5 \%$ e $87 \%$, respectivamente para os reatores com poliestireno, PET e PVC, os quais operaram com tempo de detenção hidráulica relativo a altura do leito, correspondente ao volume reacional dos reatores $\left(\mathrm{TDH}_{\mathrm{r}}\right)$ de $22 \mathrm{~h}, 10,6 \mathrm{~h}$ e $20,4 \mathrm{~h}$, respectivamente. A quantificação de polímeros extracelulares mostrou melhores resultados para as partículas de PVC que apresentou 0,2 mgCarboidrato/gPartícula e 0,06 mgProteina/gPartícula. No entanto, deformações nessas partículas prejudicaram o desempenho do reator, definindo como melhor 
suporte as partículas de PET, sendo que neste reator a porcentagem de remoção de fenol foi maior para um menor $\mathrm{TDH}_{\mathrm{r}}$.

\subsubsection{Taxa de carregamento orgânico em reatores biológicos}

Vários trabalhos foram desenvolvidos tratando altas taxas de carregamento orgânico em reatores anaeróbios (OLIVEIRA \& FORESTI, 2004; SILVA et al., 2003, entre outros), entre eles, nos reatores UASB (OLIVEIRA \& FORESTI, 2004, entre outros), alcançando boas remoções de DQO e sólidos, e bons rendimentos de metano.

Oliveira e Foresti (2004) obtiveram o balanço de massa, a partir dos valores médios das determinações de demanda química de oxigênio (DQO) e produção de metano $\left(\mathrm{CH}_{4}\right)$, em dois reatores UASB de bancada com volume de 10,5 L tratando águas residuárias de suinocultura, submetidos a condições operacionais distintas no que diz respeito às concentrações de sólidos suspensos totais do afluente (SST de 500; 1000; 1500 e 2000 mg/L), tempo de detenção hidráulica (TDH de 30, 20, 12 e 8 h), taxas de carregamento orgânico volumétrico (TCOV de 0,8 a 8,0 kg DQO total $/ \mathrm{m}^{3}$ dia e temperatura (ambiente e controlada a $25^{\circ}$ e $30^{\circ} \mathrm{C}$ ). Verificou-se que a DQO total removida convertida em $\mathrm{CH}_{4}$ variou de 28 a $51 \%$ e a relação DQO- $\mathrm{CH}_{4}$ por DQO dissolvida removida de 0,94 a 2,07; indicando alta participação da remoção física dos sólidos do afluente, de 49 a 72\%, na remoção de DQO total nos reatores, a qual variou de 75 a 92\%. A concentração de SST do afluente, a temperatura, o TDH e a TCOV influenciaram nesse desempenho dos reatores UASB.

Silva et al. (2003), buscou uma combinação simplificada UASB+FB sem a etapa de decantação, visando principalmente ETEs de pequeno porte onde o gerenciamento do lodo de descarte é problemático. Um Filtro Biológico Percolador (FB) operando sob baixa taxa de carregamento orgânico, propiciando o crescimento sobre o meio suporte de um biofilme fino, 
bastante mineralizado (SV reduzido), produziu um efluente com nível de estabilização satisfatório para descarte direto sem clarificação. A planta piloto foi concebida pela combinação de reatores UASB + filtro biológico percolador, onde se buscou o desenvolvimento de seis FB independentes operando sob cargas orgânicas de 0,8 a 4,5 kg $\mathrm{DQO} / \mathrm{m}^{3}$.dia, utilizados como unidades de polimento do efluente anaeróbio. Os resultados obtidos demonstram que os FBs produzem efluente de boa qualidade com concentrações médias de DQO $\leq 90 \mathrm{mg} / \mathrm{L}$ e $\mathrm{SST} \leq 60 \mathrm{mg} / \mathrm{L}$, quando operados com CvDQO de 0,8 a 4,5 $\mathrm{Kg} / \mathrm{m}^{3}$.dia, após decantador secundário. Filtros biológicos quando operados com cargas volumétricas maiores, produzem efluentes mais consistentes e maiores coeficientes de produção de lodo Yt DQO aplic $=0,79(\mathrm{KgSST} / \mathrm{KgDQO}$ aplic). A eficiência global do sistema na remoção de DQO sem etapa de decantação é de 73\%, 74\%, 74\%, 73\%, 77\% e 78\% nos respectivos FB1, FB2, FB3, FB4, FB5 e FB6, apresentando-se como um sistema que pode ser utilizado no polimento de efluentes anaeróbios.

\subsubsection{Biorreatores empregados para o tratamento anaeróbio de fenol}

O tratamento anaeróbio de compostos fenólicos tem sido proposto por vários autores e, com reatores em escala piloto, resultados satisfatórios têm sido obtidos (COSTA, 1994). Os compostos aromáticos podem ser degradados por diferentes processos anaeróbios, como: fotometabolismo, metabolismo dependente do nitrato, em ambientes redutores de sulfato e sob condições metanogênicas (KENNES et al., 1997).

Cheng et al. (1991) realizaram estudos em dois RALF, um com alimentação de fenol e o outro com mistura de fenol, catecol e $p$-cresol. Os reatores foram construídos com altura de $200 \mathrm{~cm}$ e diâmetro interno de $15 \mathrm{~cm}$. O topo foi conectado em um separador de fases de 50 $\mathrm{cm}$ de altura e $30 \mathrm{~cm}$ de diâmetro. O reator para tratamento de fenol foi preenchido com $3 \mathrm{~kg}$ 
de carvão ativado granular de 10x20 mesh $(2,0-0,84 \mathrm{~mm})$. Os reatores foram encamisados com água a temperatura de $35 \pm 1^{\circ} \mathrm{C}$.

A alimentação com fenol só foi feita após período de aclimatação com glicose. A concentração foi aumentada de 200 a 3000 mg/L em 500 dias. Avaliando o efeito cumulativo de DQO de entrada e saída e a produção de metano durante o tratamento experimental, concluíram que $88 \%$ da DQO alimentada foi convertida em biogás pelas arquéias anaeróbias, enquanto somente $9,6 \%$ foi adsorvida e convertida a biofilme no carvão. Deste modo, a biodegradação foi a maior responsável pela remoção de fenol do sistema.

Os pesquisadores observaram boa operação do sistema para concentração de fenol na entrada de até 2000 mg/L. Para operação com 2000 mg/L de fenol, TDH de 1,85 dia e COV de $2,57 \mathrm{~kg}$ DQO $/ \mathrm{m}^{3}$ dia houve remoção praticamente completa de fenol. Nestas condições a produção diária de biogás foi de 28,9 L/dia. Para concentração de alimentação de 4000 mg/L de fenol, TDH de 0,95 dia e COV de 10,02 kg DQO $/ \mathrm{m}^{3}$ dia houve sobrecarga do sistema, que precisou ficar uma semana em operação sem alimentação para a recuperação e degradação do fenol que ficou adsorvido no carvão. No estudo do tratamento dos compostos fenólicos, fenol, catecol e p-cresol na razão de 20:8:7, observaram que em altas concentrações a taxa de produção de gás diminui. $\mathrm{O}$ fenol foi o composto mais facilmente degradável enquanto o $p$ cresol foi o composto mais tóxico.

Costa (1994) avaliou o potencial da utilização do reator anaeróbio de leito fluidificado de carvão ativado no tratamento de água residuária contendo fenol. O reator foi construído em tubo de PVC com $164 \mathrm{~cm}$ de comprimento e $49 \mathrm{~mm}$ de diâmetro interno com um decantador de $46 \mathrm{~cm}$ de comprimento e $49 \mathrm{~mm}$ de diâmetro interno. Foi feita a caracterização porosimétrica do carvão $(1,00-2,38 \mathrm{~mm})$, avaliando também as possibilidades de interferência do mesmo sobre o sistema anaeróbio. Verificou que a capacidade de adsorção do carvão se alterou com as características do adsorbato, e que a capacidade de adsorção do 
fenol pelo carvão ativo variou com a concentração de carvão, com o tempo de contato ebtre eles, e com a variação do pH da solução. A eficiência de remoção de fenol variou de 65,7 a 99\% e de DQO variou de 50,3 a 94\%. A carga orgânica aplicada variou de 0,37 a 9,79 $\mathrm{kgDQO} / \mathrm{m}^{3}$ dia e o TDH de 0,05 a 0,16 dias.

Fang et al. (1996) realizaram a degradação de fenol em reator UASB de 2,8 L. A partida foi feita com alimentação de sacarose a taxa de $10 \mathrm{~g} \mathrm{DQO/L} \mathrm{dia.} \mathrm{A} \mathrm{concentração} \mathrm{de}$ fenol na corrente de alimentação foi de $430 \mathrm{mg} / \mathrm{L}$. Para DQO alimentada de $2000 \mathrm{mg} / \mathrm{L}$ a eficiência de redução foi mantida em $81 \%$. A inabilidade de aumentar a eficiência de redução de DQO foi atribuída ao efeito tóxico da alta concentração de fenol a biomassa granular do reator. Para diminuir a toxicidade, diluiu-se a alimentação com reciclo de parte do efluente. A eficiência de redução aumentou para 92,5\%. A diminuição na temperatura de $37^{\circ} \mathrm{C}$ para $20^{\circ} \mathrm{C}$ afetou a bioatividade dos grânulos degradadores de fenol, causando diminuição da produção de biogás. O reator operou por 3 meses em estado estacionário com TDH de 12 horas e $6 \mathrm{~g}$ DQO/L dia correspondente a DQO de 3000 mg/L (1260 mg fenol/L) com redução média de DQO solúvel de $94,7 \%$.

Fang e Zhou (1999) conduziram experimentos em reator UASB para investigar a eficiência do tratamento de água residuária contendo fenol (200 mg/L), m-cresol (100 mg/L) e nitrato. Foram examinadas a influência de carboidrato como co-substrato, sacarose, e as interações entre as arquéias metanogênicas e bactérias desnitrificantes. Não foram detectados produtos intermediários tais como, nitrito, benzoato, propionato e butirato no efluente. A ausência de nitrito sugeriu que a conversão de nitrato a nitrito foi o passo limitante da taxa na desnitrificação. A ausência de benzoato sugeriu que a degradação do benzoato apresentou taxa maior que a conversão de fenol e $m$-cresol a benzoato. A atividade metanogênica foi afetada pela presença de nitrito na água residuária. Isto porque as nitrificantes passaram a competir com as metanogênicas pelo substrato. 
A capacidade da biomassa degradar fenol e $m$-cresol melhorou com o aumento da metanogênese e a completa desnitrificação. Para níveis de nitrato de $368 \mathrm{mg} / \mathrm{L}$ ou superiores, 98,5\% do fenol foi removido. No entanto, a capacidade das metanogênicas degradaram o $m$ cresol foi ainda limitada. Somente $60 \%$ do $m$-cresol foi degradado. Para concentrações de nitrato de $595 \mathrm{mg} / \mathrm{L} 98 \%$ do $m$-cresol foi removido. Nesta condição todo o substrato foi utilizado pelos microrganismos desnitrificantes porque houve interrupção da produção de metano. Estes resultados indicaram que as desnitrificantes têm capacidade superior de degradar o $m$-cresol do que as metanogênicas. Na ausência de co-substrato as desnitrificantes degradaram quase $100 \%$ do fenol e do $m$-cresol.

Fang e Zhou (2000) realizaram estudo para avaliar o tratamento de água residuária contendo fenol e $p$-cresol em dois reatores UASB. O $p$-cresol foi escolhido por ser um dos poluentes fenólicos mais encontrados e por ser mais recalcitrante à biodegradação e mais tóxico aos anaeróbios do que o fenol. A razão da concentração de fenol e $p$-cresol foi mantida em 3:1. O reator A foi utilizado para estudar o efeito do tempo de detenção hidráulica (TDH), o qual foi reduzido de 12 horas até 2 horas. O reator B foi empregado para estudar o efeito do aumento das concentrações dos fenólicos para tempo de detenção hidráulica de 24 horas.

Durante a partida dos reatores sacarose foi adicionada como co-substrato. A concentração inicial de sacarose de $2000 \mathrm{mg} / \mathrm{L}$ foi gradativamente diminuída com o aumento correspondente das concentrações de fenol e $p$-cresol. No final da partida a sacarose estava totalmente ausente na água residuária, enquanto as concentrações de fenol $/ p$-cresol foram $600 / 200 \mathrm{mg} / \mathrm{L}$ para o reator A e $680 / 250 \mathrm{mg} / \mathrm{L}$ para o reator B.

Os resultados mostraram remoção de $95 \%$ de fenol, $65 \%$ de $p$-cresol e $85 \%$ de DQO para TDH entre 8-12 horas, para menores TDH a eficiência diminuiu. O reator B foi capaz de remover 75-80\% de DQO para concentrações de fenol entre 1200 - 1500 mg/L. Para concentrações maiores de fenol a eficiência de remoção diminuiu. A inibição da bioatividade 
pelos resíduos fenólicos não foi permanente e pode ser recuperada após diminuição da concentração de fenólicos na água residuária.

Tay et al. (2001) estudaram a biodegradação anaeróbia de fenol em dois reatores UASB em paralelo, adicionando glicose como co-substrato. Em um reator foi adicionado somente fenol (1260 mg/L) como fonte de carbono, reator A, e no outro, glicose $(1000 \mathrm{mg} / \mathrm{L})$ e fenol (1260 mg/L), reator B. Em estado estacionário, os reatores A e B operaram com uma COV de 6 e 8 g DQO/L.dia, respectivamente. Observou-se que a glicose acelerou a aclimatação consideravelmente e, o lodo do sistema com adição de glicose apresentou melhor desempenho quanto à eficiência de remoção de fenol, produção de biogás e qualidade do lodo. A bioatividade do lodo foi deteriorada gradualmente sob condições de alta concentração de fenol sem adição de glicose. A glicose fez a biodegradação de fenol mais completa devido ao maior crescimento do lodo e taxa de reação e, consequentemente, menor carga aplicada ao lodo de fenol e toxidez. O fenol foi degradado nos dois reatores UASB, sendo as eficiências de remoção de $88 \%$ e $98 \%$ para os reatores A e B, respectivamente. A glicose aumentou a estabilidade operacional quando o sistema foi exposto a choques de carga orgânica e mudanças de temperatura. Os dois reatores se recuperaram após o período de choque.

Bolaños (2001) estudou a remoção de fenol presente em água residuária sintética em um reator anaeróbio horizontal de leito fixo (RAHLF) sob condições mesofílicas. O RAHLF foi preenchido com lodo anaeróbio imobilizado em matrizes de espuma de poliuretano. Para um TDH de $12 \mathrm{~h}$ a concentração de fenol adicionada foi variada de 50 a $1200 \mathrm{mg} / \mathrm{L}$. Com 50 mg/L, após 33 dias o reator atingiu uma remoção de fenol de 97\%. Com 100 mg/L e depois de 148 dias de operação não foi detectado fenol no efluente do reator. Com 300 mg/L e após 58 dias de operação o reator apresentou $99 \%$ de remoção e uma concentração no efluente de 0,85 mg/L. Com 600, 900 e 1200 mg/L após 47, 29 e 7 dias, respectivamente, o reator alcançou 
remoções de 99\%. Em todas as concentrações foi observado o predomínio de Methanosaeta, Methanobacterium e cocos metanogênicos.

Pullammanappallil et al. (2001) avaliaram o desempenho da digestão anaeróbia na presença de altas concentrações de ácido propiônico. Os experimentos foram feitos em digestor de 1,7 L automaticamente controlado. As condições normais de operação foram taxa de diluição de $0,05 \operatorname{dia}^{-1}$ e temperatura de digestão de $35^{\circ} \mathrm{C}$. A alimentação consistiu de meio com glicose $(28 \mathrm{~g} / \mathrm{L})$ e propionato $(1 \mathrm{~g} / \mathrm{L})$. Para simular um distúrbio tóxico, fenol a concentração de $40 \mathrm{~g} / \mathrm{L}$ foi adicionado à alimentação e alimentado no digestor por $36 \mathrm{~h}$. Imediatamente após a adição do fenol a taxa de produção de metano começou a cair. A inabilidade do sistema em operar quando o fenol foi adicionado indicou que o processo foi inibido. O grau de inibição foi de $50 \%$ porque a taxa de diluição foi reduzida pela metade pelo sistema de controle utilizado. As concentrações de acido acético e butírico permaneceram abaixo de $100 \mathrm{mg} / \mathrm{L}$, no entanto, ácido propiônico acumulou até $2750 \mathrm{mg} / \mathrm{L}$. O fenol inibiu todos os grupos tróficos de organismos e as analises indicaram que o acido propiônico foi produzido a partir do fenol. O ácido propiônico acumulou proporcional a redução da concentração de fenol. A resposta do sistema mostrou que mesmo com altas concentrações de acido propiônico o processo não ficou desbalanceado. Durante a operação metade da glicose foi alimentada e a taxa de produção de metano foi reduzida à metade. Sendo assim, a inibição do processo foi devido ao fenol, a degradação de fenol resultou no acumulo de acido propiônico e esse acumulo pode ter sido efeito e não a causa da inibição do processo de conversão da glicose a metano.

Sancinetti (2004) estudou a degradação de fenol em reator anaeróbio de leito fluidificado. Foram realizados ensaios em batelada objetivando comparar o desempenho de diferentes inóculos na degradação do fenol. Foi comparado o lodo proveniente de abatedouro de aves bruto, imobilizado em espuma de poliuretano e empregado para tratamento da 
vinhaça com o lodo proveniente de resíduo de suinocultura em ensaios sem prévia adaptação ao fenol. O lodo proveniente de resíduo de suinocultura apresentou melhores resultados, passando por etapa de adaptação ao fenol, e foi empregado nos ensaios em batelada para obtenção dos parâmetros cinéticos de consumo de fenol e no reator anaeróbio de leito fluidificado (RALF). O estudo cinético mostrou que a maior velocidade de reação foi obtida para a concentração de fenol de $355 \mathrm{mg} / \mathrm{L}$. O RALF foi operado com tempo de detenção hidráulica de 24 h e a partícula utilizada como material suporte foi o poliestireno $(2,2 \mathrm{~mm})$. As seguintes concentrações de fenol foram aplicadas no reator: 50, 100, 200, 300, 400 e 500 $\mathrm{mg} / \mathrm{L}$. Os resultados foram satisfatórios para todas as concentrações de fenol empregadas, apresentando eficiência de remoção de fenol acima de 95\% e redução de DQO acima de $85 \%$. As observações em microscópio eletrônico de varredura mostraram boa adesão microbiana e a visualização em microscópio ótico indicou presença de bacilos retos, ovalados, víbrios, espiralados e cocos, além da presença de morfologias semelhantes a Methanosaeta sp. Em todas as fases de operação do reator.

Fang et al. (2004) trataram uma água residuária sintética que contém fenol como único substrato a $26^{\circ} \mathrm{C}$, em um reator anaeróbio de manta de lodo (UASB), onde removeu a cima de $98 \%$ de fenol com uma concentração de até $1260 \mathrm{mg} / \mathrm{L}$ de fenol operado com tempo de detenção hidráulica de $12 \mathrm{~h}$, correspondendo a 6,0 g de DQO/L.dia. Os resultados mostraram que o benzoato foi o intermediário fundamental na degradação do fenol. A conversão de benzoato para metano foi suprimida pela presença de fenol. Baseado na análise DNA cloning analysis, observou que o lodo era composto de cinco grupos de microrganismos. Os Desulfotomaculum e Clostridium foram provavelmente responsáveis pela conversão de fenol para benzoato que era mais adiante degradado pelas Syntrophus a acetato e $\mathrm{H}_{2} / \mathrm{CO}_{2}$. Os Methanogens converteram ultimamente o acetato e $\mathrm{H}_{2} / \mathrm{CO}_{2}$ para metano. Porém, o papel da epsilo-Proteobacteria não foi bem identificado. 
Segundo Veeresh et al. (2005) o reator anaeróbio de manta de lodo (UASB) foi aplicado com sucesso no tratamento de águas residuárias municipal e industrial. Diversos pesquisadores estudaram a aplicação do processo de tratamento de fenóis e águas residuárias contendo fenol. O tratamento de fenol ainda está numa fase de estudos. Para aumentar o conhecimento da utilização do reator UASB no tratamento de águas residuárias contendo fenol e cresol (o-, $m$ - e $p$ - isomeros), foram realizados diversos estudos de viabilidade para o tratamento. Concentrações de 500-750 mg/L de fenol geralmente não possui nenhuma inibição no tratamento utilizando o reator UASB. Concentrações de fenol maior que 500 mg/L podem ser tratadas por inóculos adaptados, pela recirculação do efluente tratado e/ou suplementação com co-substratos como a glicose. A degradabilidade do fenol é maior que a do $p$-cresol, que em troca é maior que $m$ - e $o$-cresol.

Matsuda (2005) estudou a viabilidade técnica da integração entre o Processo Oxidativos Avançados (POA), baseado na reação foto-Feton, e o sistema de lodos ativados. Em uma primeira etapa um efluente sintético, apresentando fenol como poluente modelo (1000 mgC/L), é pré-tratado pelo processo foto-Fenton, através de um reator tubular contendo 12 lâmpadas UV (40 W/lâmpada). Espécies aromáticas são convertidas a ácidos orgânicos e outros compostos provavelmente menos agressivos, tornando o meio viável à atividade microbiana. Este efluente pré-tratado é introduzido em um sistema contínuo de lodos ativados para complementar a oxidação da matéria orgânica residual. Simultaneamente, foi realizado o estudo dos fatores envolvidos na integração entre os processos, especialmente as concentrações residuais de fenol $(20-100 \mathrm{mgC} / \mathrm{L})$ e de peróxido de hidrogênio $(0,1-1,5$ mmol/L) após o pré-tratamento fotoquímico. Os efeitos dessas variáveis e de suas interações (efeitos sinérgicos) quanto ao desempenho do reator biológico foram investigados via técnica de superfície de resposta, a partir de um planejamento experimental Doehlert. 
Kuşçu e Sponza (2006a) estudaram o tratamento anaeróbio de água residuária sintética contendo $p$-nitrofenol (p-NP) com concentração de 80 de mg/L em um sistema de reatores seqüenciais anaeróbio/aeróbio com taxa de carregamento orgânico de 0,3 a 3,16 kg de $\mathrm{DQO} / \mathrm{m}^{3}$ dia. O sistema utilizado foi um reator em batelada ABR/CSTR em escala de laboratório consistindo em um reator anaeróbio em batelada ABR com volume efetivo de 28,8 L e um reator aeróbio CSTR com volume efetivo de 9 L.

Neste estudo, a taxa de carregamento foi aumentada gradativamente de 0,3 a $3,16 \mathrm{~kg}$ de $\mathrm{DQO} / \mathrm{m}^{3}$ dia. O tempo de detenção hidráulica variou de 1 a 10,38 dias correspondendo ao aumento da taxa de carregamento orgânico. As eficiências de redução de DQO e remoção de p-NP observadas foram de $99 \%$ e $98 \%$, respectivamente para uma taxa de carregamento orgânico de $0,3 \mathrm{~kg}$ de $\mathrm{DQO} / \mathrm{m}^{3}$ dia $(\mathrm{TDH}=10,38$ dias) no reator $\mathrm{ABR}$. A eficiência de redução de DQO e remoção de $p$-NP no reator ABR diminuiu de $99 \%$ para $71 \%$ e de $98 \%$ para $90 \%$, respectivamente, com o aumento da taxa de carregamento orgânico de 0,3 para 3,16 kg de $\mathrm{DQO} / \mathrm{m}^{3}$ dia. A eficiência global de redução de DQO e remoção de $p$-NP do sistema de reatores seqüenciais anaeróbio/aeróbio foi acima de $94 \%$ com taxa de carregamento orgânico de até $2,1 \mathrm{~kg}$ de $\mathrm{DQO} / \mathrm{m}^{3}$ dia.

Estes pesquisadores obtiveram resultados relacionados a produção de biogás, onde mostraram que a produção do gás total e gás metano aumentaram enquanto a porcentagem de metano diminuiu com o aumento da taxa de carregamento orgânico. A produção diária de gás total, gás metano e porcentagem de metano foram de $2220 \mathrm{~mL} / \mathrm{dia}, 920 \mathrm{~mL} / \mathrm{dia}$ e $39 \%$ a uma taxa de carregamento orgânico de $0.3 \mathrm{~kg}$ de $\mathrm{DQO} / \mathrm{m}^{3}$ dia, respectivamente. Os parâmetros acima mencionado encontrados foram de 17,696 mL/dia, $4320 \mathrm{~mL} /$ dia e $16 \%$ a uma taxa de carregamento orgânico de $3,16 \mathrm{~kg}$ de $\mathrm{DQO} / \mathrm{m}^{3}$ dia, respectivamente.

Neste estudo, o pH, ácido volátil total (AVT) e alcalinidade a bicarbonato (AB)/ácido volátil total (AVT) variou no efluente e em todos os compartimentos do ABR 
foram satisfatórios para a otimização do tratamento anaeróbio para todas as taxas de carregamento orgânico. Os valores de pH variaram entre 6,9 e 7,6 no efluente e em todos os compartimentos do ABR. A concentração de AVT diminuiu longitudinalmente no ABR de afluente para efluente nos compartimentos do ABR. A concentração de AVT no efluente foi zero até uma taxa de carregamento orgânico de $1,28 \mathrm{~kg}$ de $\mathrm{DQO} / \mathrm{m}^{3} \mathrm{dia}$. As relações de $\mathrm{AVT} / \mathrm{AB}$ no efluente do ABR foram mais baixas que 0,4 para todas as taxas de carregamento orgânico. Os resultados mostraram que 95 a 100\% de $p$-NP mineralizaram a $p$-AP em todo o sistema. O p-AP e fenol foram convertidos para produtos finais no CSTR. A nitrificação do $\mathrm{NH}_{4}-\mathrm{N}$ para $\mathrm{NO}_{2}-\mathrm{N}$ e $\mathrm{NO}_{3}-\mathrm{N}$ foi observada na fase aeróbia.

Kuşçu e Sponza (2006b) estudaram o tratamento anaeróbio do $p$-nitrofenol ( $p$-NP) foi estudado em um sistema de reatores seqüenciais anaeróbio/aeróbio sob um aumento de carregamento orgânico durante período de operação de 186 dias. O sistema utilizado foi um reator em batelada AMBR/CSTR em escala de laboratório consistindo em um reator anaeróbio em batelada AMBR com volume efetivo de 13,5 L e um reator aeróbio CSTR com volume efetivo de 9 L. A água residuária sintética utilizada conteve concentração constante de $40 \mathrm{mg} / \mathrm{L}$ de $p$-NP e uma concentração de glicose de $3000 \mathrm{mg} / \mathrm{L}$ de DQO como substrato primário. Os estudos foram desenvolvidos em um sistema contínuo e o efluente do reator AMBR foi usado como o alimento para o reator CSTR. O sistema AMBR/CSTR foi operado sob taxas de carregamento orgânicos (TCOs) variando de 0,31 a 3,25 kg de DQO/m² dia. As eficiências de redução de DQO e remoção de $p$-NP reduziram de $92 \%$ para $79 \%$ e de $94 \%$ para $86 \%$, respectivamente, quando a taxa de carregamento orgânico relacionada a DQO foi aumentada de 0,31 a $3,25 \mathrm{~kg}$ de $\mathrm{DQO} / \mathrm{m}^{3}$ dia no AMBR. As eficiências de redução de DQO total e remoção de $p$-NP foram de $94 \%$ e $91 \%$ em todo o sistema (AMBR/CSTR), respectivamente, a uma taxa de carregamento orgânico relacionada a DQO de 3,25 $\mathrm{kg}$ de $\mathrm{DQO} / \mathrm{m}^{3}$ dia. 
Neste estudo, o gás total e a produção de gás metano aumentou com o aumento das TCOs. As produções diárias de gás total e de gás metano foram de 12,25 e 3,8 L/dia a TCO de 3,25 $\mathrm{kg}$ de $\mathrm{DQO} / \mathrm{m}^{3}$ dia, respectivamente. A porcentagem de gás de metano produzido foi de $31 \%$ para esta taxa de carregamento. Neste estudo, o pH, ácido volátil total (AVT) e alcalinidade a bicarbonato (AB)/ácido volátil total (AVT) variou no efluente e em todos os compartimentos do AMBR foram satisfatórios para a otimização do tratamento anaeróbio para todas as taxas de carregamento orgânico. $\mathrm{O}$ pH, AVT e a relação AB/AVT no efluente em todos os compartimentos do AMBR foi obtido entre 7,2-7,64, 290-353 mg/L e 0,06-0,13, respectivamente, a TCO de $3,25 \mathrm{~kg}$ de $\mathrm{DQO} / \mathrm{m}^{3}$ dia. Entre $79-92 \%$ do $p$-NP foram transformados a $p$-amino fenol ( $p$-AP) na fase anaeróbia. A geração de fenol e amônia $\left(\mathrm{NH}_{4}-\right.$ N) foi observada durante a degradação anaeróbia. A mineralização completa do $p$-AP $(\mathrm{E}=$ $100 \%)$ foi obtida na fase aeróbia. $\mathrm{O} p$-AP, fenol, e $\mathrm{NH}_{4}-\mathrm{N}$ foram convertidos a nitrito $\left(\mathrm{NO}_{2}-\right.$ $\mathrm{N})$, nitrato $\left(\mathrm{NO}_{3}-\mathrm{N}\right)$ e $\mathrm{CO}_{2}$ como produtos finais na fase aeróbia.

Fang et al. (2006) estudaram a degradação de fenol em um reator anaeróbio de manta de lodo de fluxo ascendente (UASB) a $55^{\circ} \mathrm{C}$ com $40 \mathrm{~h}$ de tempo de detenção hidráulico (TDH) para uma água residuária contendo $630 \mathrm{mg} / \mathrm{L}$ de fenol, correspondendo a $1500 \mathrm{mg} / \mathrm{L}$ de demanda de oxigênio química (DQO) e um taxa de carregamento orgânico de 0,9 g de DQO/L.dia. A eficiência de remoção de fenol foi acima de 99\%. A máxima atividade metanogênica específica (AME) do lodo para a degradação do fenol foi de 0,09 g- $\mathrm{CH}_{4}$ DQO/g-sólidos suspensos voláteis (SSV)/d. Baseado na análise 16S rDNA, um total de 21 unidades operacionais de taxonomia (UOTs) foi achado dentro do lodo onde oito $(42,6 \%$ da população total) foram encontradas na seqüência do GenBank com semelhança de mais de 97\%, e $13(79,6 \%)$ se afiliou com espécies conhecidas de termofílicas. Dados adicionais de SMA e análise filogenética sugerem que a rota metabólica para a degradação do fenol por lodo termofílico foi provável via caproato, em vez de benzoato como pelo lodo mesofílico. 


\section{CAPÍTULO 3}

\section{MATERIAIS E MÉTODOS}

Neste capítulo serão apresentados a configuração do sistema utilizado para o desenvolvimento da parte experimental, juntamente com os métodos adotados para avaliar o desempenho do reator anaeróbio de leito fluidificado.

\subsection{Reator anaeróbio de leito fluidificado}

O reator utilizado para o experimento foi construído em acrílico transparente de $5 \mathrm{~mm}$ de espessura e apresenta as seguintes dimensões: altura de $190 \mathrm{~cm}$ e diâmetro interno de 5,3 cm. Os amostradores intermediários ao longo do comprimento do reator foram colocados a 20 $\mathrm{cm}, 40 \mathrm{~cm}, 70 \mathrm{~cm}, 110 \mathrm{~cm}$ e $160 \mathrm{~cm}$ da base do reator. A temperatura foi mantida em $30 \pm 1$ ${ }^{\circ} \mathrm{C}$ por meio de encamisamento do reator em banho termostatizado.

O reator possuía um volume total de $4192 \mathrm{~cm}^{3}$, deste, $1368 \mathrm{~cm}^{3}$ foi ocupado pelo suporte.

A Figura 3.1 mostra o esquema da instalação piloto do reator anaeróbio de leito fluidificado que foi utilizada para o estudo da degradação do fenol, apresentando todos os componentes utilizados durante a operação do sistema. 


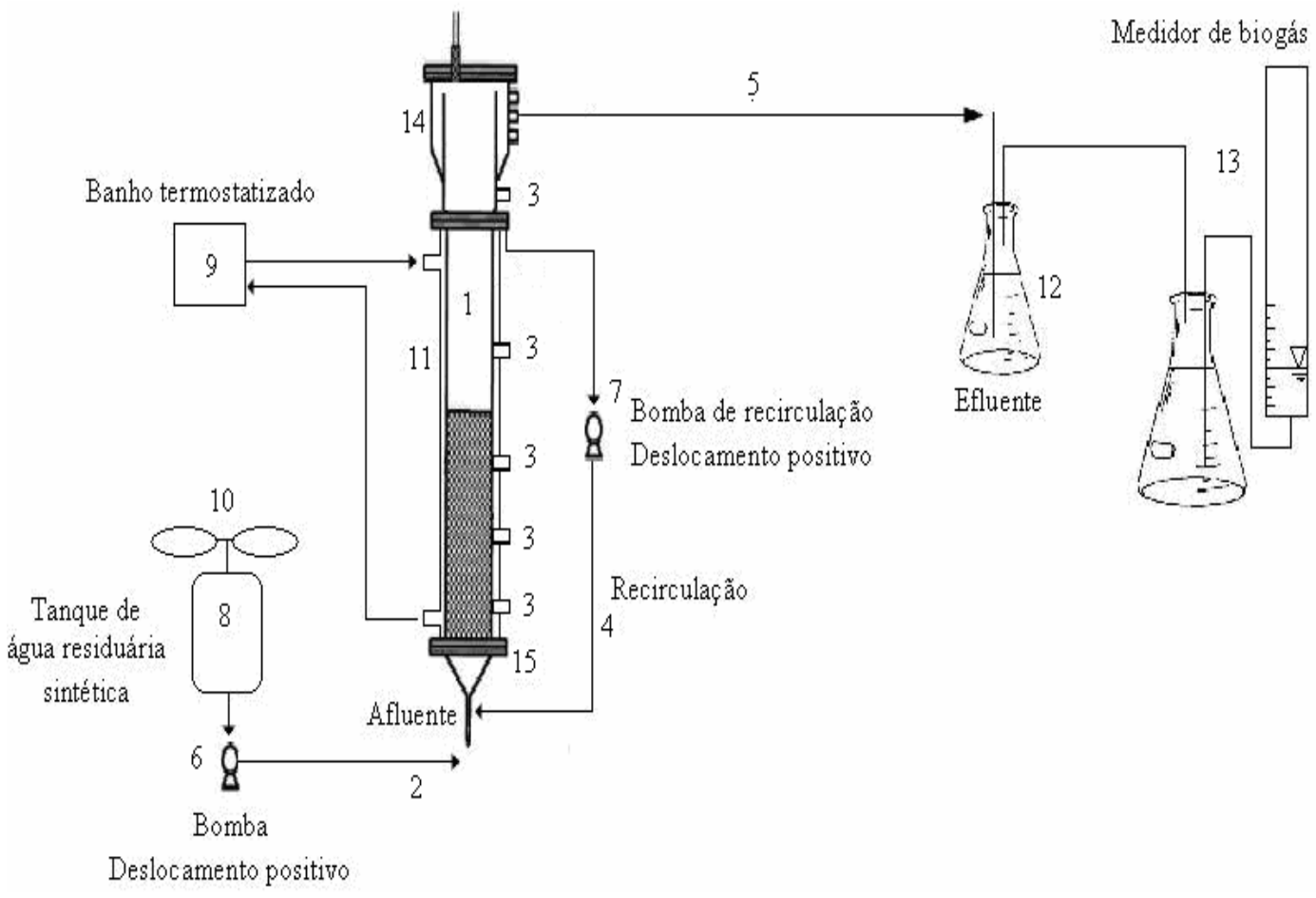

Figura 3.1 - Esquema da instalação do reator anaeróbio de leito fluidificado: (1) Reator de leito fluidificado, (2) entrada do afluente, (3) amostradores, (4) recirculação, (5) saída do efluente, (6) bomba de alimentação, (7) bomba de recirculação, (8) reservatório de alimentação, (9) banho termostatizado, (10) bexigas com nitrogênio, (11) encamisamento para o banho, (12) reservatório do efluente, (13) medidor de biogás, (14) câmara de captação de gás, (15) distribuidor da alimentação.

A bomba de alimentação (6) utilizada foi a DOSITEC, modelo DLX MA/A, cuja vazão e pressão máxima foram de $1 \mathrm{~L} / \mathrm{h}$ e 15 Bar, respectivamente, e bomba de recirculação (7) utilizada foi a ECOSAN-Bomba dosadora, cuja vazão varia de 10 a $200 \mathrm{~L} / \mathrm{h}$ e pressão de $6 \mathrm{~kg} / \mathrm{cm}^{2}$.

O sistema para manter o reator com temperatura constante utilizado foi banho ultratermostatizado Marconi modelo 184 (9). 
A Figura 3.2 mostra uma fotografia do reator utilizado e as Figuras 3.3 a 3.5 mostram, em detalhe, alguns dos componentes do reator anaeróbio de leito fluidificado.

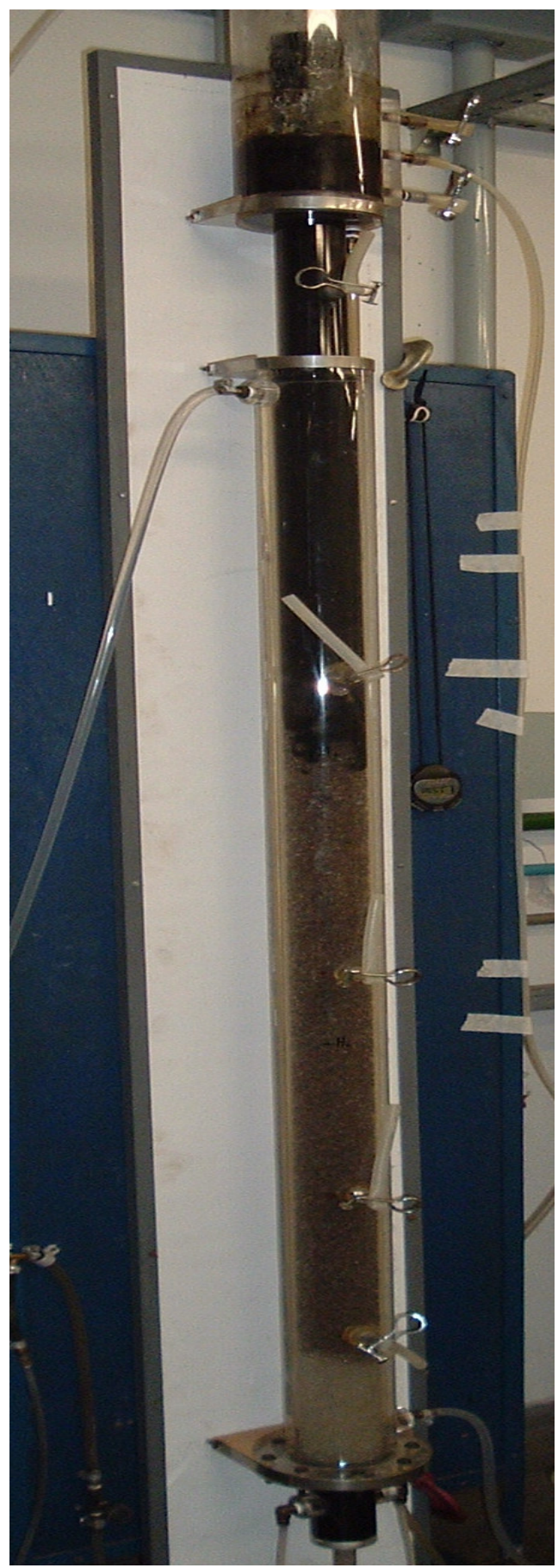

Figura 3.2 - Reator anaeróbio de leito fluidificado. 


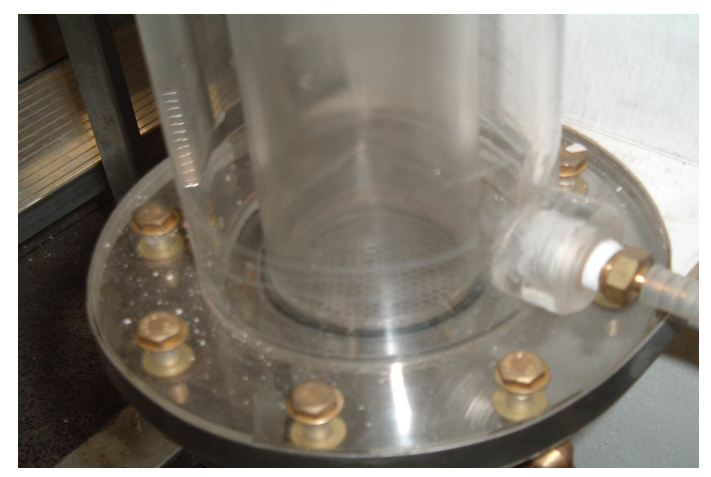

Figura 3.3 - Distribuidor da alimentação.

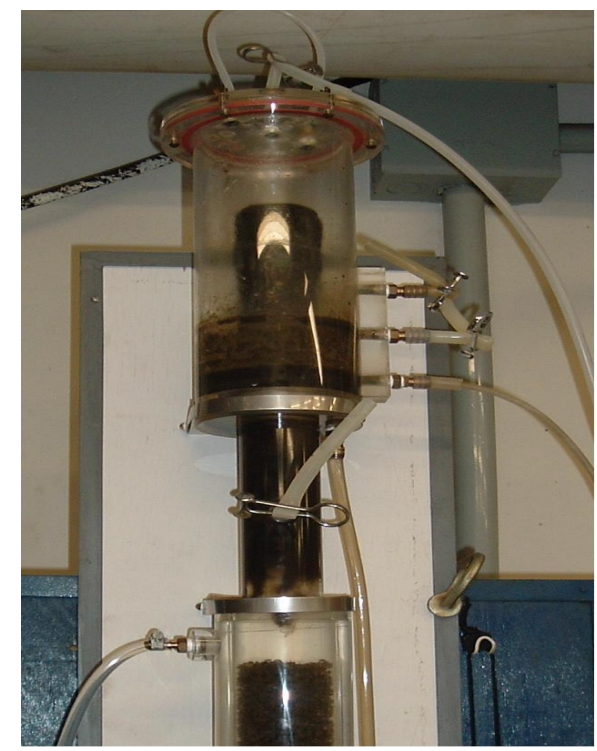

Figura 3.4 - Topo do reator (Câmara de captação de gás e dispositivo para saída do efluente).

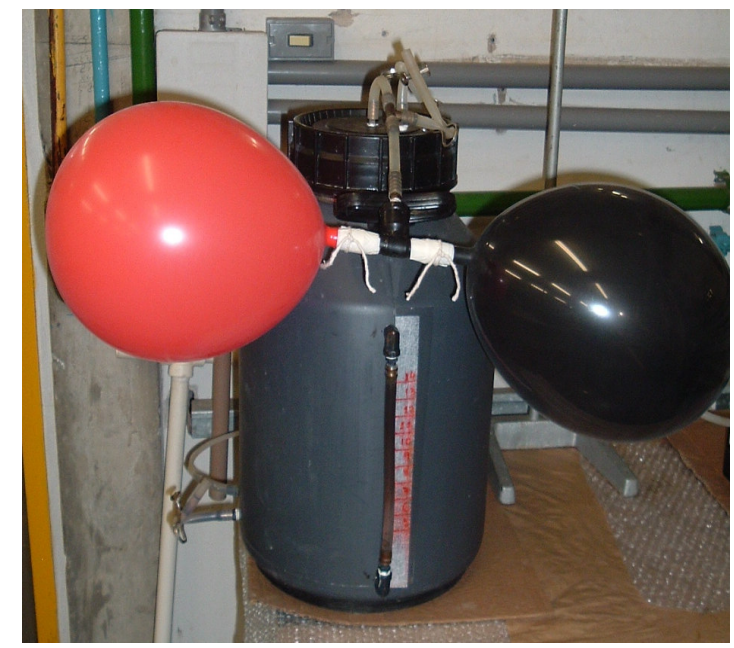

Figura 3.5 - Reservatório de alimentação (Barrilete). 


\section{2 Água residuária sintética}

A água residuária sintética alimentada ao reator foi preparada de acordo com Del Nery (1987) substituindo a glicose como principal fonte de carbono pelo fenol. A composição aproximada é mostrada na Tabela 3.1.

Tabela 3.1 - Composição da água residuária sintética a base de fenol para DQO de 1000 $\mathrm{mg} / \mathrm{L}$.

\begin{tabular}{cc}
\hline Composto & Concentração (mg/L) \\
$\mathrm{C}_{6} \mathrm{H}_{5} \mathrm{OH}$ & 300,0 \\
$\mathrm{NH}_{2} \mathrm{CON}_{2}$ & 62,5 \\
$\mathrm{NiSO}_{4} .7 \mathrm{H}_{2} \mathrm{O}$ & 0,5 \\
$\mathrm{FeSO}_{4} \cdot 7 \mathrm{H}_{2} \mathrm{O}$ & 2,5 \\
$\mathrm{FeCl} 6 \mathrm{H}_{2} \mathrm{O}$ & 0,25 \\
$\mathrm{CaCl}_{2} \cdot 2 \mathrm{H}_{2} \mathrm{O}$ & 23,5 \\
$\mathrm{CoCl}_{2} \cdot 6 \mathrm{H}_{2} \mathrm{O}$ & 0,04 \\
$\mathrm{SeO}_{2}$ & 0,035 \\
$\mathrm{KH}_{2} \mathrm{PO}_{4}$ & 42,5 \\
$\mathrm{~K}_{2} \mathrm{HPO}_{4}$ & 10,85 \\
$\mathrm{Na}_{2} \mathrm{HPO}_{4} \cdot 7 \mathrm{H}_{2} \mathrm{O}$ & 16,7 \\
$\mathrm{NaHCO}_{3}$ & 1000,0 \\
\end{tabular}

A alimentação dos nutrientes para preparo da solução foi feita com valores constantes desde o início ao fim da operação do reator conforme apresentado na Tabela 3.1. A partir do 
início da operação do sistema foi adicionado extrato de levedura $(0,05 \%)$ na solução de alimentação.

A água residuária foi armazenada em um barrilete de 20 L, onde era substituído a cada 3 dias. Para garantir anaerobiose no reator fluxionou-se gás $\mathrm{N}_{2}(100 \%)$ no barrilete de alimentação. $\mathrm{O}$ barrilete possui duas bexigas acopladas e preenchidas com $\mathrm{N}_{2}(100 \%)$ conforme visualizado na Figura 3.5. Onde à medida que o substrato de alimentação fosse retirado do reservatório, o mesmo não seria contaminado com a atmosfera ambiente. Evitando, assim, a contaminação com $\mathrm{O}_{2}$ no reator.

Durante a realização da parte experimental do presente trabalho (182 dias) foi efetuada variação progressiva na concentração de fenol de 50 a $700 \mathrm{mg} / \mathrm{L}$, afim de avaliar o desempenho do reator.

\subsection{Inóculo}

O inóculo utilizado no reator foi lodo proveniente de reator anaeróbio de manta de lodo (UASB) que tratava água residuária de suinocultura.

\subsection{Suporte empregado no reator anaeróbio de leito fluidificado}

Partículas de poliestireno foram empregadas como meio suporte para a imobilização da biomassa, o mesmo utilizado por Martinelli (2003), Sancinetti (2004) e Sader (2005), conforme mostrada na Figura 3.6. As características das partículas como dimensão, densidade e velocidade de mínima fluidificação estão apresentadas na Tabela 3.2. 


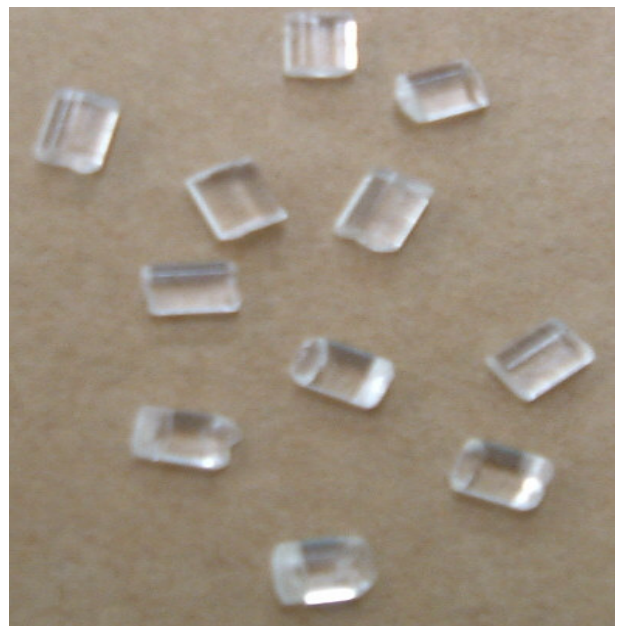

Figura 3.6 - Partículas de poliestireno.

Tabela 3.2 - Dimensão, densidade e velocidade de mínima fluidificação para as partículas de poliestireno.

\begin{tabular}{cccc}
\hline Partícula & $\Phi(\mathrm{mm})^{*}$ & $\rho\left(\mathrm{g} / \mathrm{cm}^{3}\right)$ & $\mathrm{V}_{\mathrm{mf}}(\mathrm{cm} / \mathrm{s})$ \\
\hline poliestireno & $2,2 \times 2,2$ & 1,05 & 0,74
\end{tabular}

Fonte: Martinelli (2003)

(*) partículas de formato cilíndrico, comprimento versus diâmetro.

As partículas de poliestireno foram tratadas segundo o método utilizado por Tavares (1992). Primeiramente foram mergulhas em solução sulfocrômica por 40 minutos, em seguida lavadas com água, secas e mergulhadas em ácido nítrico concentrado por 50 minutos. Posteriormente, foram lavadas novamente e secas em estufa a $40{ }^{\circ} \mathrm{C}$. No entanto, este procedimento foi aplicado quatro vezes para as partículas de poliestireno, de forma identica ao procedimento usado por Sancinetti (2004), que observou em microscopia óptica e de varredura o aumento gradativo da presença de rugosidade nestas partículas. Por fim, foram colocadas no reator para realizar a adaptação do inóculo ao fenol. 


\subsection{Adaptação do inóculo ao fenol e início da operação}

No tratamento biológico de efluentes industriais, em especial àqueles projetados para remoção de poluentes potencialmente tóxicos, torna-se necessário a adaptação da população microbiana para que ela seja capaz de degradá-los, garantindo o bom desempenho do processo.

O método utilizado para a adaptação da biomassa foi o da adaptação dos microrganismos no próprio sistema de tratamento biológico, contendo as partículas de poliestireno utilizadas como meio suporte, utilizando-se como inóculo a biomassa de reator UASB conforme citado no item 3.3. Com a finalidade de manter a atividade microbiana do inóculo utilizado, uma água residuária sintética contendo fenol a uma concentração de 50 $\mathrm{mg} / \mathrm{L}$ foi utilizada como despejo sintético na alimentação do sistema.

O primeiro passo desta etapa foi ajustar as condições fluidodinâmicas do reator. Para isto, foram utilizados os dados experimentais de velocidade de mínima fluidificação de Martinelli (2003), para partículas de poliestireno de 2,2 $\mathrm{mm}$ de diâmetro em reator de leito fluidificado similar ao utilizado neste trabalho. Com estes dados foi possível calcular a vazão de recirculação necessária para que o reator atingisse as condições de fluidificação, ou seja, correspondente a $1,3 \mathrm{vez} \mathrm{V}_{\mathrm{mf}}$. $\mathrm{O}$ valor da velocidade de mínima fluidificação para a partícula de poliestireno foi de $0,74 \mathrm{~cm} / \mathrm{s}$, porém o utilizado durante a operação do sistema foi 0,962 $\mathrm{cm} / \mathrm{s}\left(1,3\right.$ vez $\left.\mathrm{V}_{\mathrm{mf}}\right)$ e com o uso de um medidor de vazão acoplado no reator a bomba foi regulada.

Inicialmente, o reator foi preenchido com as partículas até uma altura de $62 \mathrm{~cm}$, cuja massa correspondente foi de $750 \mathrm{~g}$ de partículas de poliestireno.

A próxima etapa foi o acionamento da bomba dosadora da ECOSAN, deixando o sistema permanecer em recirculação como se estivesse em batelada com uma vazão de 
recirculação de $76 \mathrm{~L} / \mathrm{h}$, correspondendo a 1,3 vez a vazão mínima de fluidificação. A altura de fluidificação atingida foi de $100 \mathrm{~cm}$. Nesta fase, monitorou-se a concentração de fenol do inóculo para que, em seguida, retirasse o reservatório de inóculo, acoplando mangueira de alimentação, passando assim a operar o sistema continuamente.

A Figura 3.7 mostra o esquema da instalação piloto do reator anaeróbio de leito fluidificado durante a etapa de partida.

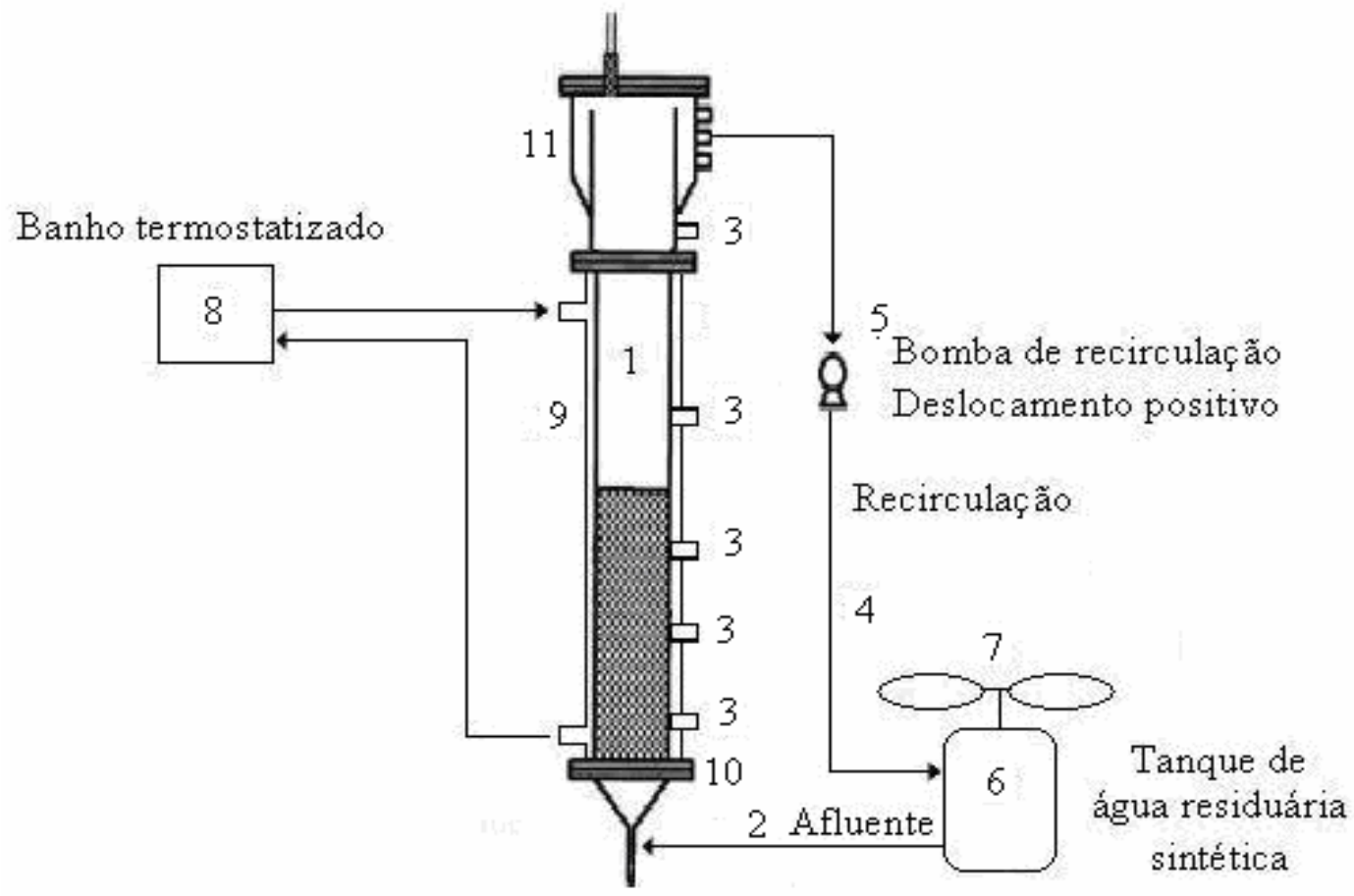

Figura 3.7 - Esquema da instalação do reator anaeróbio de leito fluidificado durante a etapa de partida: (1) Reator de leito fluidificado, (2) entrada do afluente, (3) amostradores, (4) recirculação, (5) bomba de recirculação, (6) reservatório de alimentação, (7) bexigas com nitrogênio, (8) banho termostatizado, (9) encamisamento para o banho, (10) distribuidor da alimentação, (11) câmara de captação de gás. 
A Tabela 3.3 mostra os parâmetros utilizados no reator anaeróbio de leito fluidificado durante a etapa de inoculação.

Tabela 3.3 - Parâmetros usados no reator de leito fluidificado.

\begin{tabular}{cccccc}
\hline Partícula & $\mathrm{Q}_{\mathrm{r}}(\mathrm{L} / \mathrm{h})$ & $\mathrm{M}(\mathrm{g})$ & $\mathrm{H}_{\mathrm{o}}(\mathrm{cm})$ & $\mathrm{H}_{\mathrm{f}}(\mathrm{cm})$ & $\mathrm{C}_{\mathrm{f}}(\mathrm{mg} / \mathrm{L})$ \\
\hline Poliestireno & 76 & 750 & 62 & 100 & 50 \\
\hline
\end{tabular}

onde: $\mathrm{Q}_{\mathrm{r}}$ : vazão de recirculação;

$\mathrm{M}$ : massa de partículas usada no reator;

$\mathrm{H}_{\mathrm{o}}$ : altura correspondente a massa de partículas em leito fixo;

$\mathrm{H}_{\mathrm{f}}$ : altura correspondente a massa de partículas em leito fluidificado;

$\mathrm{C}_{\mathrm{f}}$ : concentração de fenol no inóculo.

A inoculação foi efetuada introduzindo-se no reator anaeróbio de leito fluidificado o inóculo desenvolvido em barrilete (20 L) contendo 15 L de inóculo, desses, $10 \%$ correspondia ao lodo de reator anaeróbio e o restante, água residuária sintética contendo uma concentração de $50 \mathrm{mg} / \mathrm{L}$ de fenol. Foi adicionado nitrogênio no "headspace" do barrilete e mantido em recirculação no reator através de uma bomba de deslocamento positivo e a temperatura de 30 ${ }^{\circ} \mathrm{C}$ foi controlada através de banho termostático.

Neste experimento adotou-se o sistema de recirculação entre o barrilete e o reator com o objetivo de adaptar o lodo no próprio reator, objetivando realizar uma partida mais rápida que Sancinetti (2004) e Sader (2005).

Durante 14 dias, o reator foi operado em circuito fechado. Durante este período, para analisar o consumo de substrato pelos microrganismos foram retiradas amostras periódicas para análise da concentração de fenol e à medida que o fenol era consumido, adicionava-se 
solução para atingir concentração correspondente a $50 \mathrm{mg} / \mathrm{L}$ de fenol no barrilete de alimentação.

O reator começou a receber afluente de forma contínua após o período de 14 dias de recirculação (ver Figura 3.1), com concentração de fenol de aproximadamente $50 \mathrm{mg} / \mathrm{L}$ com vazão de alimentação pela bomba DOSITEC de $175 \mathrm{~mL} / \mathrm{h}$, correspondendo ao tempo de detenção hidráulica (TDH) de $24 \mathrm{~h}$, considerando todo o volume do reator $\left(4200 \mathrm{~cm}^{3}\right)$. Adotando o procedimento realizado por Bolaños (2001) e Sancinetti (2004) para o cálculo do TDH, considerando-se o volume útil reacional $\left(1548,86 \mathrm{~cm}^{3}\right)$, o TDH obtido para as condições operacionais do reator anaeróbio de leito fluidificado foi de $8,85 \mathrm{~h}$

Para facilitar a análise dos resultados, a pesquisa foi dividida em oito fases, principalmente em função dos diferentes valores da concentração de fenol afluente.

Na Tabela 3.4 apresentam-se de forma objetiva, os valores correspondentes a concentração de fenol em cada fase de operação que variou entre $50 \mathrm{mg} / \mathrm{L}$ a $700 \mathrm{mg} / \mathrm{L}$ e suas respectivas durações.

O dia inicial da operação, correspondente a amostragem inicial, foi considerado após operação contínua por 1 dia.

As mudanças nas fases de operação ocorreram após a avaliação do desempenho do reator relacionando as eficiências de remoção de fenol e redução de DQO, além dos outros parâmetros monitorados como: alcalinidade, ácidos voláteis totais e $\mathrm{pH}$. Durante cada mudança de fase, partículas de poliestireno foram retiradas para análise de microscopia eletrônica de varredura (MEV). 
Tabela 3.4 - Fases em que a pesquisa foi desenvolvida.

\begin{tabular}{ccc}
\hline Fase & Concentração de fenol no afluente (mg/L) & Duração (Dias) \\
\hline I & 50 & 13 \\
II & 100 & 44 \\
III & 200 & 2 \\
IV & 300 & 59 \\
V & 400 & 10 \\
VI & 500 & 23 \\
VII & 600 & 6 \\
VIII & 700 & 25 \\
\hline
\end{tabular}

\subsection{Métodos analíticos}

As análises físico-químicas foram efetuadas periodicamente. Todas as análises foram realizadas em amostras filtradas em membrana $0,45 \mu \mathrm{m}$, exceto sólidos voláteis totais. As análises de pH, DQO, sólidos totais (ST), sólidos suspensos totais (SST) e sólidos suspensos voláteis (SSV) foram feitas de acordo com o APHA: Standard Methods for the Examination of Water and Wastewater (1995). As concentrações de ácidos voláteis totais, expressas como ácido acético foram analisados de acordo com metodologia proposta por Dillalo e Albertson (1961) e alcalinidade, como $\mathrm{CaCO}_{3}$, conforme metodologia modificada por Ripley et al. (1986).

A metodologia empregada para análise de fenol foi a da CETESB L5.125 Determinação de fenóis em águas - Método colorimétrico da 4-amino-antipirina (CETESB, 1990). A utilização desta metodologia se deu por ter sido utilizada nos trabalhos de Silva 
(1995), Bertollo (2001), Sancinetti (2004) e Sader (2005) apresentando resultados satisfatórios.

Tabela 3.5 - Freqüência de coleta e análise de amostras para todas as fases de operação.

\begin{tabular}{cc}
\hline Análises & Freqüência \\
\hline pH & Diária \\
Fenol & $3 x$ semana \\
DQO & $3 x$ semana \\
Ácidos voláteis totais & $2 x$ semana \\
Alcalinidade & $2 x$ semana \\
Vazão & 4 x diária \\
ST, SST e SSV & $1 \times$ semana \\
\hline
\end{tabular}

\subsubsection{Determinação de ácidos voláteis por cromatografia}

A análise cromatográfica para determinação de ácidos voláteis em amostras gasosas foi desenvolvida no Laboratório de Processos Biológicos - Setor Cromatografia do Departamento de Hidráulica e Saneamento (SHS) da Escola de Engenharia de São Carlos (EESC) da Universidade de São Paulo (USP), nas seguintes condições:

Cromatógrafo gasoso HP 6890;

Detector - TCD;

Coluna HP INNOWAX - $30 \mathrm{~m}$ x 0,25 mm (diâmetro interno) x 0,25 $\mu \mathrm{m}$ de espessura de biofilme;

Temperatura do injetor $=250{ }^{\circ} \mathrm{C}$; temperatura do detector $=300{ }^{\circ} \mathrm{C}\left(\mathrm{H}_{2}=30 \mathrm{~mL} / \mathrm{min}\right.$, ar sintético $=300 \mathrm{~mL} / \mathrm{min}, \mathrm{N}_{2}=33 \mathrm{~mL} / \mathrm{min}$. Range $=1$ ); 
Temperatura do forno $=100{ }^{\circ} \mathrm{C}(3 \mathrm{~min}), 180{ }^{\circ} \mathrm{C}(10 \mathrm{~min}), 5{ }^{\circ} \mathrm{C} / \mathrm{min}$. O fluxo do gás de arraste $\left(\mathrm{H}_{2}\right)$ foi de $2,0 \mathrm{~mL} / \mathrm{min}$.

Para evitar a danificação das colunas cromatográficas foi realizada extração dos ácidos das amostras com éter etílico, previamente purificado por destilação. Na extração, a 2,0 mL de amostra foram adicionados $1,0 \mathrm{~g}$ de $\mathrm{NaCl}, 100 \mu \mathrm{L}$ de solução de $\mathrm{H}_{2} \mathrm{SO}_{4}-1 \mathrm{M}, 100 \mu \mathrm{L}$ de solução de ácido crotônico $700 \mathrm{mg} / \mathrm{L}$ e 0,6 mL de éter etílico. A mistura dessas soluções foi agitada no vórtex por $1 \mathrm{~min}$, centrifugada a $3000 \mathrm{rpm}$ por $1 \mathrm{~min}$ e finalmente injetados no cromatógrafo $1,0 \mu \mathrm{L}$ da fase orgânica.

\subsubsection{Caracterização microbiológica do biofilme anaeróbio}

A morfologia das bactérias e a análise estrutural do biofilme foram avaliadas em microscópio eletrônico de varredura (Digital Scanning Microscope DSM 960, ZEISS).

A metodologia adotada para preparação dos suportes para MEV foi adaptada para biofilmes microbianos por Araújo (1995). As etapas realizadas serão as seguintes:

a) Fixação

Colocar a amostra em tubo de ensaio com glutaraldeído 2,5\% em tampão fosfato $0,1 \mathrm{M}$ $\mathrm{pH} 7,3$ gelado, deixando aproximadamente 12 horas na geladeira $\left(4^{0} \mathrm{C}\right)$.

b) Lavagem

Lavar as amostras três vezes com tampão fosfato $0,1 \mathrm{M}$ pH 7,3 (gelado), durante 10 minutos cada lavagem.

c) Desidratação

A desidratação foi feita em álcool etílico gelado, considerando o seguinte procedimento: 
$50 \%$ - uma vez, durante 10 minutos,

$70 \%$ - uma vez, durante 10 minutos,

$80 \%$ - uma vez, durante 10 minutos,

$90 \%$ - uma vez, durante 10 minutos,

$95 \%$ - uma vez, durante 10 minutos,

$100 \%$ - três vezes, durante 10 minutos cada.

d) Secagem 1

Foi transferido o material suporte para placa de petri e foi colocado hexametildisilazani (HMDS), deixando por 30 segundos. O procedimento foi realizado duas vezes.

e) Secagem 2

As amostras foram fixadas no suporte para MEV, usando esmalte incolor. O material foi transferido para estufa com temperatura de $35{ }^{0} \mathrm{C}$ e mantido por 1 a 2 horas.

f) Recobrimento com ouro

A amostra foi recoberta com ouro e observada em MEV. O microscópio eletrônico utilizado foi o ZEISS DSM 960 do Instituto de Física de São Carlos da Universidade de São Paulo.

\subsubsection{Determinação da produção de metano}

O metano existente no biogás formado foi determinado por cromatografia gasosa com detector de ionização de chama (FID), utilizando um cromatógrafo modelo GC-17A da marca Shimadzu. As condições de operação foram:

Cromatógrafo gasoso Shimadzu - 17A;

Detector - FID 
Coluna GC - $30 \mathrm{~m}$ x 0,32 mm (diâmetro interno) x 0,25 $\mu \mathrm{m}$ de espessura de biofilme;

Temperatura do injetor $=90{ }^{\circ} \mathrm{C}$; temperatura do detector $=370{ }^{\circ} \mathrm{C}$;

Temperatura do forno $=250{ }^{\circ} \mathrm{C}$. O fluxo do gás de arraste $\left(\mathrm{H}_{2}\right)$ foi de $2,0 \mathrm{~mL} / \mathrm{min}$.

\subsubsection{Exame microscópico}

Foram realizados exames microscópicos das amostras do reator para as fases de operação, através de luz comum, contraste de fase e fluorescência em microscópio Olympus BX60-FLA. As imagens foram captadas através da câmera Optronics e software Image ProPlus versão 3.0.1, sendo possível observar microrganismos presentes nas amostras. 


\section{CAPÍTULO 4}

\section{RESULTADOS E DISCUSSÕES}

Neste capítulo serão apresentados os principais resultados dos parâmetros analisados para controle do desempenho do reator anaeróbio de leito fluidificado empregado na presente pesquisa. As informações básicas foram mostradas através de curvas de variação dos principais parâmetros analisados, abrangendo todo o período de coleta de dados, e são apresentadas tabelas com os valores médios correspondentes a cada fase de operação do reator.

Todos os resultados das análises de rotina realizados durante a operação do reator são apresentados no Anexo A. Neste anexo são apresentados dados sobre o afluente e efluente do reator em relação aos seguintes parâmetros: fenol, DQO, pH, alcalinidade, ácidos voláteis totais, sólidos totais, sólidos suspensos totais e sólidos suspensos voláteis.

\subsection{Adaptação do inóculo ao fenol}

Speece (1996) comenta que o potencial de adaptação da biomassa anaeróbia a muitos tóxicos pode ser alcançado se o bom senso e a paciência forem empregados na exposição da biomassa, primeiramente a concentrações relativamentes baixas, antes de se aumentar as concentrações para os valores máximos pretendidos. Este procedimento que garante a adaptação da biomassa ocorrerá sob condições favoráveis e em concentrações de tóxicos biodegradáveis dentro do reator mantidas em nível significantemente mais baixo que aquele da água residuária em questão. 
Durante a fase de adaptação do inóculo ao fenol, no reator operado em circuito fechado, foram retiradas amostras periódicas, com horário fixo, para análise do consumo de fenol pelos microrganismos.

O consumo de substrato pelos organismos ao longo do tempo está apresentado na Tabela 4.1. A Tabela apresenta os resultados obtidos durante os 14 dias de adaptação. 
Tabela 4.1 - Resultados obtidos durante os 14 dias de adaptação do inóculo.

\begin{tabular}{|c|c|}
\hline Tempo (dias) & Concentração de Fenol (mg/L) \\
\hline 0 & 45 \\
\hline 1 & 45 \\
\hline 1 & 41 \\
\hline 2 & 2 \\
\hline $2(*)$ & 54 \\
\hline 3 & 45 \\
\hline 4 & 39 \\
\hline 5 & 1 \\
\hline 6 & 1 \\
\hline 7 & 1 \\
\hline $7(*)$ & 51 \\
\hline 8 & 35 \\
\hline 9 & 1 \\
\hline $9(*)$ & 55 \\
\hline 10 & 2 \\
\hline 11 & 2 \\
\hline $12(*)$ & 58 \\
\hline 13 & 41 \\
\hline 14 & 1 \\
\hline
\end{tabular}

(*) análises realizadas após suplementação de fenol no barrilete. 
A Figura 4.1 mostra os resultados das concentrações de fenol durante os 14 dias de adaptação. Durante 14 dias de operação, verificou-se uma rápida adaptação da biomassa, com registro de concentrações de fenol no efluente variando de 1 a 2 mg/L.

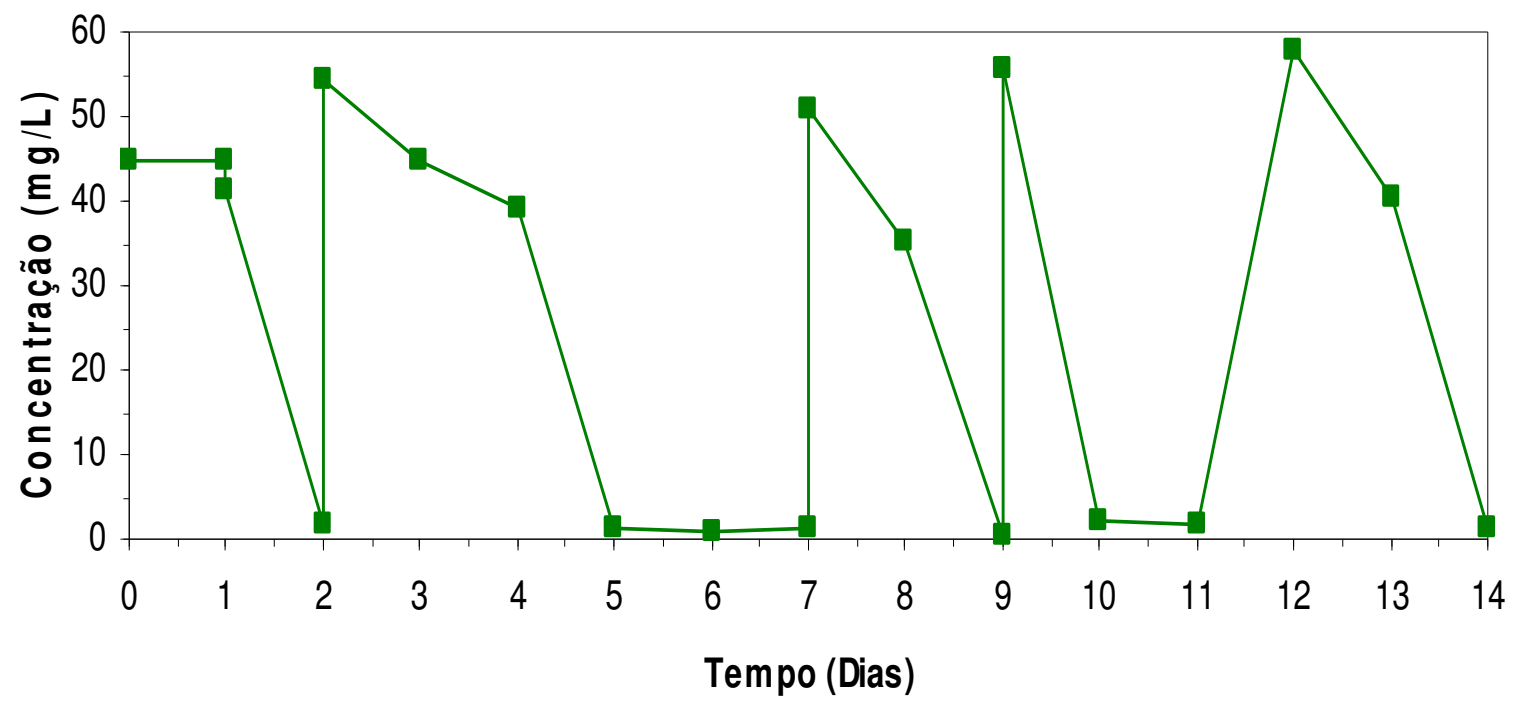

Figuras 4.1 - Variação temporal da degradação do fenol na adaptação do inóculo.

Nota-se, no início do período de adaptação, que o fenol foi consumido em aproximadamente 2 dias, e quando se observava o consumo deste, mais fenol era adicionado.

O período de adaptação total foi de 14 dias, no final destes, o inóculo estava adaptado para concentrações próximas a $50 \mathrm{mg} / \mathrm{L}$ de fenol. Esta etapa de adaptação foi de grande importância neste trabalho, facilitando posteriormente a partida do reator.

Os resultados obtidos, nas condições estudadas, demonstraram a capacidade do consórcio microbiano em adaptar-se a efluentes potencialmente tóxicos. Deve-se, entretanto, salientar que a adaptação depende de vários fatores, entre os quais, concentração do tóxico e as condições de operação.

De acordo com Speece (1996), o fator chave para um tratamento estável e eficiente de efluentes contendo elevada toxicidade é fornecer um adequado fator de segurança biológico 
ao sistema, ou seja, um alto TRC (tempo de retenção celular). Segundo o mesmo autor, com a adaptação adequada, a concentração de certos tóxicos pode ser até 10 vezes maior que aquela suportada por lodo não adaptado.

\subsubsection{Morfologias observadas no inóculo}

No final dos 14 dias da adaptação do inóculo, foram retiradas amostras do reator e visualizadas em microscópio óptico com a finalidade de observar as morfologias presentes.

A Figura 4.2 mostra que as morfologias encontradas são semelhantes a Methanosaeta $s p$., além da presença de bacilos e víbrios. As morfologias encontradas nesse experimento foram semelhantes às encontradas por Sancinetti (2004) e Sader (2005). 


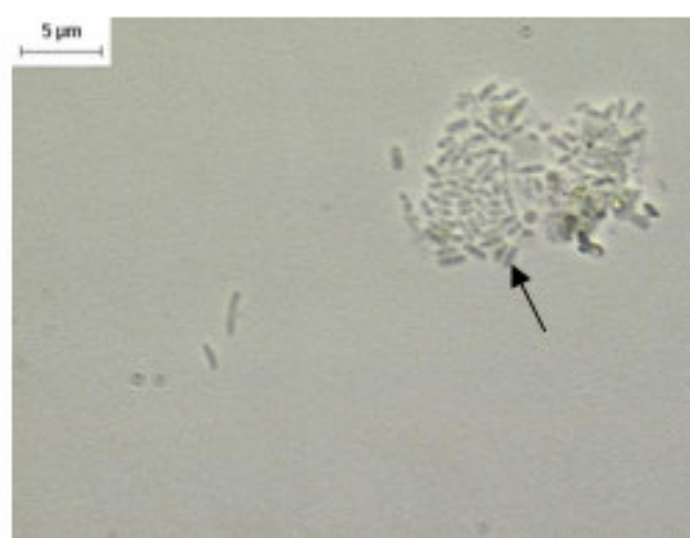

(a)

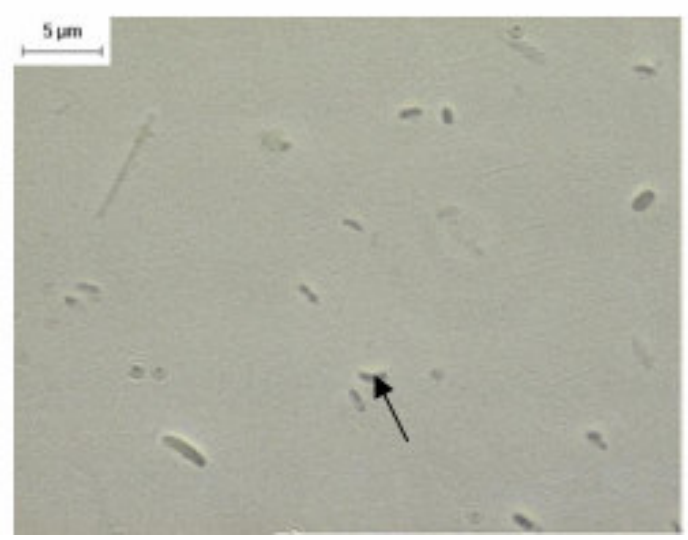

(c)

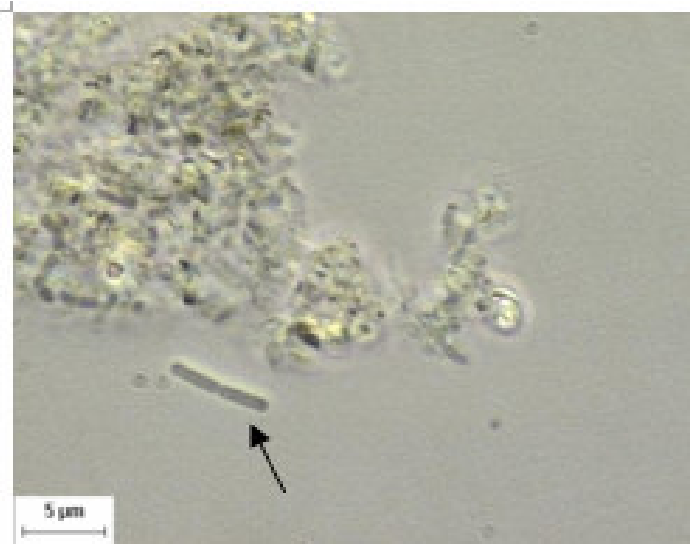

(b)

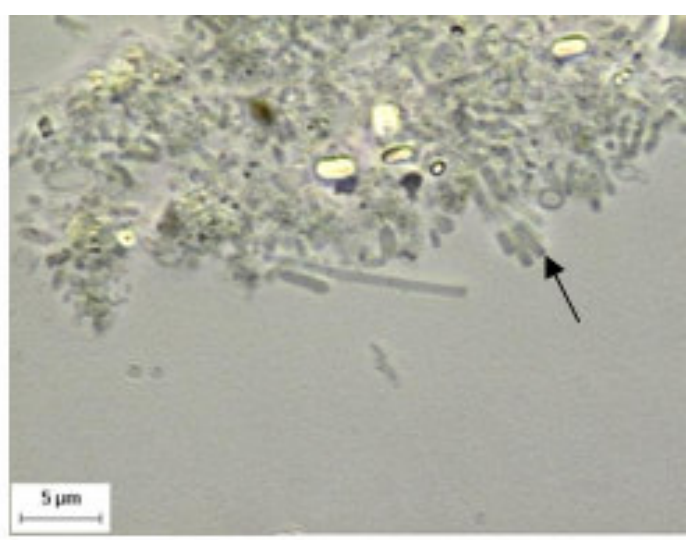

(d)

Figura 4.2 Morfologias observadas na adaptação do inóculo: (a), (b) bacilos, (c) víbrios e (d) morfologias semelhantes à Methanosaeta sp.

\subsection{Degradação anaeróbia de fenol em reator anaeróbio de leito fluidificado}

\subsubsection{Remoção de fenol para reator preenchido com partículas de poliestireno}

As Figuras 4.3 a 4.5, mostram os resultados obtidos para a vazão de efluente, e os resultados da degradação de fenol ao longo das fases de operação do reator.

A Figura 4.3 ilustra a vazão medida no efluente do reator. Nota-se que ocorreram algumas variações na vazão durante o período de operação do sistema. As prováveis variações 
podem ter ocorridas devido à sensibilidade da bomba de alimentação, além de duas válvulas que promoviam perda de carga possibilitando atingir a faixa de vazão adequada para o TDH utilizado próximo a 24 h. As oscilações na rede elétrica, também pode ter contribuído para a alteração da vazão da bomba de alimentação. A faixa de vazão durante a operação do sistema foi mantida entre $175 \pm 35 \mathrm{~mL} / \mathrm{h}$, representada pelas duas linhas horizontais mostradas na Figura 4.3.

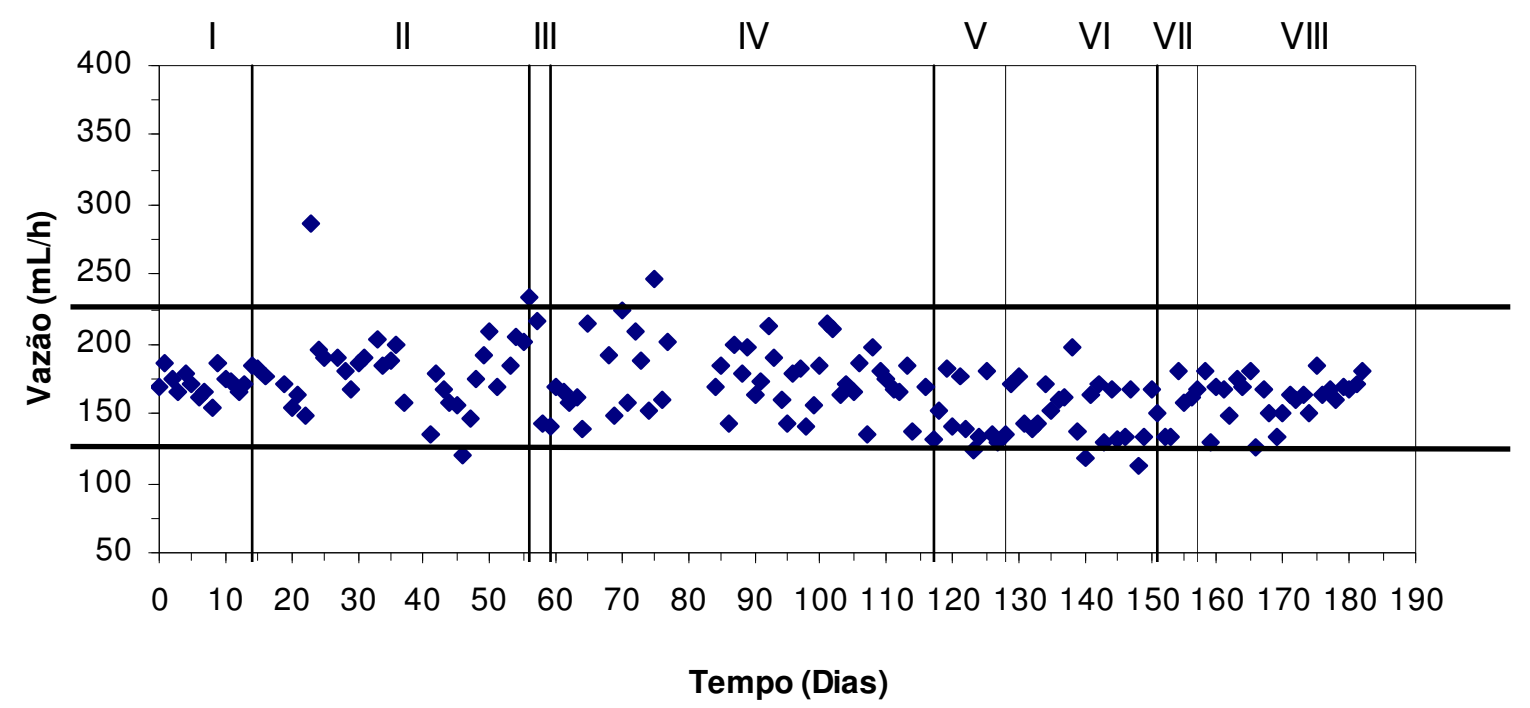

Figura 4.3 - Variação da vazão efluente ao longo do tempo para o reator preenchido com poliestireno.

A Figura 4.4 mostra como variou a concentração de fenol no afluente e no efluente do reator anaeróbio de leito fluidificado. 


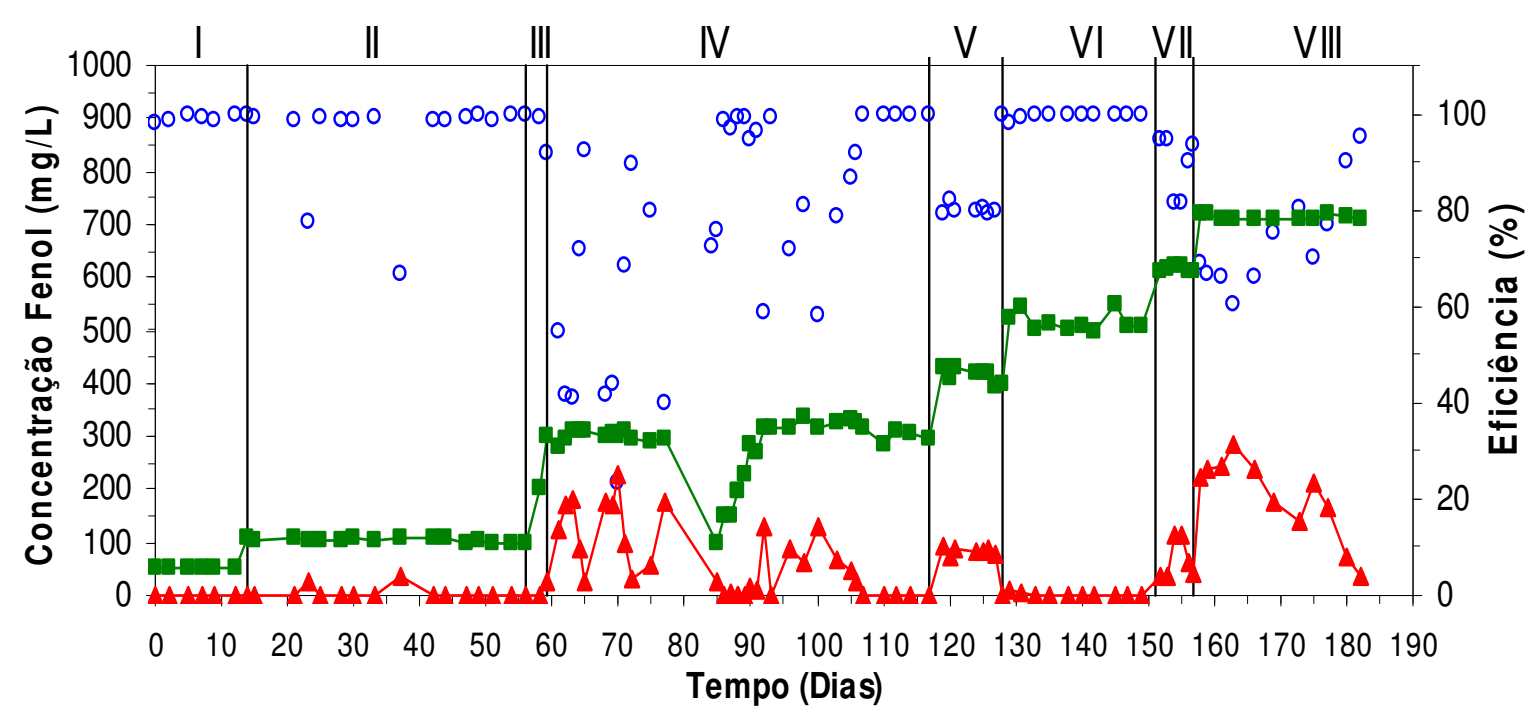

Figura 4.4 - Variação temporal da concentração de fenol afluente $\left(-{ }^{-}\right)$, efluente $\left({ }^{\star}\right)$ e eficiência de remoção de fenol $\left(^{\circ}\right)$ para o reator anaeróbio de leito fluidificado.

Pode-se considerar que a partida do reator foi rápida e que o estado estacionário foi atingido após um dia de operação continua com concentração afluente de $50 \mathrm{mg} / \mathrm{L}$ de fenol, devido à eficiência de remoção ter sido de 100\%. Sancinetti (2004), operando reator anaeróbio de leito fluidificado obteve a partida em três dias, com alimentação inicial de 50 mg/L de fenol, tempo superior ao obtido neste estudo. Pode-se atribuir essa constatação ao aprimoramento do método de adaptação do inóculo adotado por Sancinetti (2004).

Neste sistema a eficiência permaneceu em $100 \%$ até a fase IV, $59^{\circ}$ dia de operação, com exceção dos $23^{\circ}$ dia e $37^{\circ}$ dia, durante a fase II, quando a vazão de alimentação aumentou para $286 \mathrm{~mL} / \mathrm{h}$, cerca de $63 \%$ maior que a vazão utilizada e uma queda de energia que desligou a bomba de refluxo, permanecendo apenas a bomba de alimentação funcionando durante $15 \mathrm{~h}$, respectivamente, no entanto, a estabilidade foi recuperada com a carga de 100 $\mathrm{mg} / \mathrm{L}$ de fenol. 
A perda da eficiência na fase $\mathrm{IV}, 61^{\circ}$ dia de operação, pode ter sido ocasionada pela sobrecarga da concentração de fenol na alimentação, que estaria sendo aumentada de 100 mg/L para $200 \mathrm{mg} / \mathrm{L}$ e em seguida para $300 \mathrm{mg} / \mathrm{L}$.

Durante a fase IV, nos $62^{\circ}$ dia, $63^{\circ}$ dia e $68^{\circ}$ dia ocorreram quedas de energia que desligou a bomba de refluxo, permanecendo apenas a bomba de alimentação funcionando durante 12 h, 10 h e 2 h, respectivamente. Ainda na fase IV, $68^{\circ}$ dia de operação, ocorreu o empacotamento do leito ao ligar a bomba de refluxo, foi necessário aplicar jato de nitrogênio para soltar as partículas do leito, perdendo bastante biomassa. Durante a fase IV, no $69^{\circ}$ dia, ainda havia ocorrido uma perda da eficiência que provavelmente poderia ser conseqüência da perda de biomassa e queda de energia ocorrida no dia anterior.

Durante a fase IV, no $70^{\circ}$ dia e $77^{\circ}$ dia, ocorreu uma sobrecarga devido ao aumento da vazão de alimentação. Esse fato fez com que a eficiência diminuísse bruscamente atingindo $40 \%$, optando-se a partir do $77^{\circ}$ dia, por deixar o sistema em circuito fechado até verificar que todo fenol fosse degradado, ainda foi observado a ocorrência de perda de biomassa. Após o período em recirculação, o sistema foi reaberto no $83^{\circ}$ dia com $100 \mathrm{mg} / \mathrm{L}$, adicionando $1 \mathrm{~L}$ de inóculo no reator e aumentado gradualmente para $300 \mathrm{mg} / \mathrm{L}$, na condição que operou com eficiência de $100 \%$ até o $91^{\circ}$ dia, a partir daí começou a perder novamente a estabilidade, devido a sobrecargas aplicadas a essa concentração na fase IV, nos $92^{\circ}$ dia, $100^{\circ}$ dia e $103^{\circ}$ dia. Após o $103^{\circ}$ dia de operação, recuperou-se e voltou a atingir eficiência de $100 \%$.

A Tabela 4.2 apresenta os resultados médios obtidos e seus respectivos desvios para cada faixa de concentração de fenol aplicada no reator anaeróbio de leito fluidificado. 
Tabela 4.2 - Resultados médios obtidos e seus respectivos desvios, para cada faixa de concentração de fenol, aplicada no reator anaeróbio de leito fluidificado.

\begin{tabular}{cccccc}
\hline C fenol (mg/L) & \% removida & vazão $(\mathrm{mL} / \mathrm{h})$ & $\mathrm{TDH}(\mathrm{h})^{*}$ & $\mathrm{TDHr}(\mathrm{h})^{* *}$ & $\mathrm{H}_{\mathrm{f}}(\mathrm{cm})$ \\
\hline 50 & $98,9 \pm 0,6$ & 172 & 24,42 & 11,34 & 88,42 \\
100 & $95,6 \pm 9,4$ & 188 & 22,34 & 15,91 & 133,38 \\
200 & $99,3 \pm 0$ & 142 & 29,58 & 22,06 & 142,00 \\
300 & $80,6 \pm 15,5$ & 178 & 23,59 & 11,69 & 90,00 \\
400 & $82,6 \pm 7,0$ & 154 & 27,27 & 14,29 & 108,88 \\
500 & $99,4 \pm 0,5$ & 156 & 26,92 & 13,90 & 94,30 \\
600 & $89,3 \pm 6,1$ & 153 & 27,45 & 12,16 & 86,67 \\
700 & $74,2 \pm 10,7$ & 161 & 26,09 & 12,64 & 89,36 \\
\hline
\end{tabular}

* TDH: tempo de detenção hidráulica baseado na altura total do reator;

** $\mathrm{TDH}_{\mathrm{r}}$ : tempo de detenção hidráulica baseado na altura do leito $\left(\mathrm{H}_{\mathrm{f}}\right)$.

Considerando-se a altura do leito na fluidificação, ou seja, volume onde as reações ocorrem, pode-se calcular o $\mathrm{TDH}_{\mathrm{r}}$ do mesmo modo que o TDH é calculado para a altura total do reator, conhecida a área da seção transversal.

Observando os valores do $\mathrm{TDH}$ e $\mathrm{TDH}_{\mathrm{r}}$ mostrados na Tabela 4.2, a relação $\mathrm{TDH} / \mathrm{TDH}_{\mathrm{r}}$ foi aproximadamente igual a 2 para todas as faixas de concentração de fenol estudada. Este valor indica que o tempo de detenção hidráulica real $\left(\mathrm{TDH}_{\mathrm{r}}\right)$ que corresponde a altura do leito na fluidificação $\left(\mathrm{H}_{\mathrm{f}}\right)$ onde ocorrem as reações biológicas é a metade do TDH correspondente a altura total do reator.

No estudo realizado por Sader (2005) a altura de fluidificação $(63 \mathrm{~cm})$ atingiu cerca de $79 \%$ da altura total do reator $(80 \mathrm{~cm})$, e verificou-se que a razão $\mathrm{TDH} / \mathrm{TDH}_{\mathrm{r}}$ foi aproximadamente igual a 1,27 para todas as faixas de concentração de fenol estudada (100 a 
$400 \mathrm{mg} / \mathrm{L}$ ), valor inferior ao encontrado neste estudo. Esta relação quanto mais próxima de 1 indica que o substrato teria mais tempo de contato com a biomassa, podendo ser significativo para o aumento da eficiência do sistema.

Comparando os resultados obtidos neste trabalho com outros estudos de degradação anaeróbia de fenol pode-se dizer que para a carga aplicada entre $0,09 \mathrm{~kg}$ fenol $/ \mathrm{m}^{3} \mathrm{dia}$ a $1,29 \mathrm{~kg}$ fenol $/ \mathrm{m}^{3}$ dia $(50$ a $700 \mathrm{mg}$ fenol/L) os resultados foram satisfatórios e coerentes com o encontrado por outros pesquisadores em estudos de degradação de fenol em reatores anaeróbios. A Tabela 4.3 apresenta valores de outros estudos de degradação anaeróbia de fenol.

Tabela 4.3 - Parâmetros de estudos de degradação anaeróbia de fenol.

\begin{tabular}{|c|c|c|c|c|}
\hline Pesquisa & Tipo de reator & $\begin{array}{l}\text { C fenol } \\
(\mathrm{mg} / \mathrm{L})\end{array}$ & $\begin{array}{l}\text { Carga Aplicada } \\
\left(\mathrm{kg} \text { fenol } / \mathrm{m}^{3} \mathrm{dia}\right)\end{array}$ & TDH \\
\hline Cheng et al. (1991) & RALF & $200-3000$ & $1,07-4,17$ & $20-48 \mathrm{~h}$ \\
\hline Chang et al. (1995) & UASB & $150-500$ & $0,1-2,2$ & $88-5,5 \mathrm{~h}$ \\
\hline Fang et al. (1996) & UASB & $420-1260$ & $0,42-2,52$ & $8-12 h$ \\
\hline Fang e Zhou (1999) & UASB & 200 & 0,2 & $24 \mathrm{~h}$ \\
\hline Bolaños (2001) & RAHLF & $50-1200$ & $0,1-2,4$ & ${ }^{*} 12 \mathrm{~h}$ \\
\hline Fang et al. (2004) & UASB & 700 & 0,35 & $48 \mathrm{~h}$ \\
\hline Sancinetti (2004) & RALF & $50-500$ & $0,09-0,9$ & $24 \mathrm{~h}\left({ }^{*} 13,3 \mathrm{~h}\right)$ \\
\hline Sader (2005) & RALF & $10-400$ & $0,09-0,324$ & $24 \mathrm{~h}\left({ }^{*} 22,03 \mathrm{~h}\right)$ \\
\hline Fang et al. (2006) & UASB & 630 & 0,38 & $40 \mathrm{~h}$ \\
\hline Atual & RALF & $50-700$ & $0,09-1,29$ & $24 \mathrm{~h}\left({ }^{*} 14,04 \mathrm{~h}\right)$ \\
\hline
\end{tabular}

TDH considerando volume útil reacional. 
Observa-se que para o mesmo TDH o reator utilizado neste trabalho apresentou resultados superiores aos obtidos em reator UASB por Fang e Zhou (1999), uma vez que para $200 \mathrm{mg} / \mathrm{L}$ de fenol o RALF removeu carga aplicada de $0,28 \mathrm{~kg}$ fenol $/ \mathrm{m}^{3}$ dia e o reator UASB removeu $0,2 \mathrm{~kg}$ fenol $/ \mathrm{m}^{3}$. Comparando-se com as cargas aplicadas por Bolaños (2001) no RAHLF os resultados foram semelhantes para concentrações de fenol até $700 \mathrm{mg} / \mathrm{L}$, valor máximo empregado neste trabalho, apesar dos diferentes TDH empregados. Observa-se que a faixa de concentração de fenol utilizada neste trabalho foi superior a atingida por Sancinetti (2004) e Sader (2005) no reator RALF.

O desempenho dos diferentes sistemas depende de fatores como inóculo, método de imobilização da biomassa como os filmes fixos e crescimento em suspensão, composição da água residuária, método adotado para a partida do sistema, além das configurações do reator. Deste modo, pode-se dizer, de maneira geral, os reatores anaeróbios são alternativa viável para o tratamento de águas residuárias contendo fenol e, o reator de leito fluidificado com poliestireno como suporte pode ser avaliado como alternativa disponível.

A manutenção do sistema em circuito fechado por 14 dias, com concentração de fenol de $50 \mathrm{mg} / \mathrm{L}$, pode ter favorecido o desempenho do reator, além do fato de ter passado por etapa de adaptação ao fenol durante essa fase. Diferentemente de Sancinetti (2004) e Sader (2005) onde o sistema permaneceu em circuito fechado durante 7 dias e 33 dias, respectivamente, com concentração de fenol de $50 \mathrm{mg} / \mathrm{L}$ e $100 \mathrm{mg} / \mathrm{L}$, respectivamente, para que a concentração de fenol fosse degradada alcançando a condição ideal para a abertura do sistema.

Durante as fases I, II e III (50 mg/L, $100 \mathrm{mg} / \mathrm{L}$ e $200 \mathrm{mg} / \mathrm{L}$ de fenol, respectivamente) de operação do reator anaeróbio de leito fluidificado obteve praticamente $100 \%$ de remoção de fenol. 
Os valores obtidos por Sancinetti (2004) e Sader (2005), operando reatores RALF tratando água residuária sintética contendo fenol, com concentrações de fenol semelhante a água residuária utilizada neste trabalho, nas fases I, II e III, apresentadas na Tabela 4.3, com TDH de $24 \mathrm{~h}$, para a remoção de fenol afluente (100\%), foram semelhantes aos resultados obtidos neste trabalho. Essa constatação pode ser atribuída às mesmas condições citadas para as fases I, II e III em relação ao trabalho de Sancinetti (2004) e Sader (2005).

Comparando-se os valores observados nas fases I, II e III, com TDH de $24 \mathrm{~h}$, com os obtidos por Bolaños (2001), os quais para $50 \mathrm{mg} / \mathrm{L}$ de fenol, $69 \%$ foi removido, após 33 dias de operação a eficiência aumentou para $97 \%$ e para $100 \mathrm{mg} / \mathrm{L}$ de fenol, $99 \%$ foi removido, observou valores superiores. Essa constatação pode ser atribuída as diferentes condições citadas na Tabela 4.3 para as concentrações de fenol de 50 a $200 \mathrm{mg} / \mathrm{L}$, como o tipo de reator (RAHLF) e o diferente TDH (12h).

Fang e Zhou (1999) obteve, para a concentração de 200 mg/L de fenol, valor médio de remoção de fenol de $98 \%$. Comparando-se com os resultados apresentados na Tabela 4.2, na fase III, observa-se que o valor obtido para água residuária contendo $200 \mathrm{mg} / \mathrm{L}$ de fenol foi semelhante ao apresentado neste trabalho.

Na fase IV (300 mg/L de fenol) de operação do reator anaeróbio de leito fluidificado, obteve eficiência média de $81,2 \%$.

Os valores obtidos de remoção de fenol por Bolaños (2001), Sancinetti (2004) e Sader (2005) durante a operação com concentração de $300 \mathrm{mg} / \mathrm{L}$ de fenol, foram de 99\%, 86,6\% e 98\%, respectivamente, foram superiores aos obtidos neste trabalho. Essa constatação pode ser atribuída aos problemas operacionais ocorridos neste trabalho ao longo da operação da fase IV (300 mg/L) como sobrecarga devido ao aumento da vazão de alimentação e quedas de energia, podendo desequilibrar o consumo de ácidos no sistema, acumulando os ácidos 
comuns encontrados na degradação anaeróbia de fenol como acético, propiônico, isobutírico, butírico, isovalérico, valérico e capróico.

A eficiência média na fase V (400 mg/L de fenol) de operação do reator foi de $85 \%$.

O valor obtido por Sancinetti (2004) durante a operação com $400 \mathrm{mg} / \mathrm{L}$ de fenol foi de $46 \%$ de remoção de fenol, inferior ao obtido neste estudo. A provável causa indicada pelo autor foi a possibilidade da ocorrência de toxicidade por metais pesados. Segundo Chernicharo (1997), elementos e compostos como cobalto, níquel e selênio, dentre outros, podem apresentar efeito tóxico dependendo das concentrações empregadas. Em particular, a presença de baixas concentrações de cobre, zinco e níquel em estado solúvel são conhecidas como bastante tóxicas, sendo que estes sais estão associados com a maioria dos problemas de toxicidade por metais pesados no tratamento anaeróbio.

A solução adotada por Sancinetti (2004) foi cortar a alimentação deixando o sistema funcionar em recirculação num período de 7 dias. Foi observada a contaminação por fungos neste período, com isto decidiu-se em adicionar extrato de levedura na alimentação para que favorecesse aumento da biomassa. Como o rendimento não foi restabelecido, Sancinetti (2004) diminuiu a concentração para $300 \mathrm{mg} / \mathrm{L}$ aumentando-a gradualmente para 400mg/L, deste modo o reator passou a apresentar resultados satisfatórios para as condições operacionais impostas. Após a recuperação do reator, voltando a operar com $400 \mathrm{mg} / \mathrm{L}$ de fenol, a eficiência média foi de 99,3\%, valor superior ao obtido neste estudo.

No estudo realizado por Sader (2005) durante a operação do RALF a uma concentração $400 \mathrm{mg} / \mathrm{L}$ de fenol obteve eficiência média de remoção de fenol de 89\%, superior ao encontrado neste estudo. Essa constatação pode ser atribuída pelas consequiências dos problemas ocorridos durante a operação da fase anterior (fase IV, $300 \mathrm{mg} / \mathrm{L}$ de fenol), conforme citado anteriormente, além de possíveis acúmulos de ácidos orgânicos 
desequilibrando a estabilidade do sistema, e ainda pôde ter causado um efeito inibitório devido ao aumento da concentração de fenol para $400 \mathrm{mg} / \mathrm{L}$.

Comparando-se os valores observados na fase V, com TDH de 24 h e concentração de fenol de $400 \mathrm{mg} / \mathrm{L}$, com os obtidos por Chang et al. (1995), utilizando reator UASB, tratando fenol a uma concentração média de $400 \mathrm{mg} / \mathrm{L}$, obteve $50 \%$ de remoção de fenol, porém os autores promoveram a recirculação do efluente e a eficiência de remoção de fenol atingiu a 90\%, valor superior ao encontrado neste estudo operando sob a mesma concentração de fenol. Essa constatação pode ser atribuída as diferentes condições citadas na Tabela 4.3 para a concentração de fenol de $400 \mathrm{mg} / \mathrm{L}$, como o tipo de reator (UASB), diferente TDH (88 - 5,5 h), além da utilização da recirculação do efluente.

Na fase VI (500 mg/L de fenol) de operação do reator, obteve eficiência média em torno de $100 \%$ de remoção de fenol.

Sancinetti (2004) obteve eficiência de remoção de fenol de 90,5\% a uma concentração de $500 \mathrm{mg} / \mathrm{L}$. Comparando-se com os resultados apresentados na Tabela 4.2, na fase VI, o valor obtido foi superior ao apresentado por Sancinetti (2004). A provável causa que poderia ser atribuída seria que o reator poderia ter alcançado a carga limite de tratamento.

Durante a fase VII (600 mg/L de fenol), obteve-se eficiência média de remoção de fenol de $89,3 \%$.

O resultado obtido por Bolaños (2001) operando RAHLF com água residuária sintética contendo concentração de fenol de $600 \mathrm{mg} / \mathrm{L}$, foi de $99 \%$ de remoção de fenol, valor superior ao encontrado neste trabalho. Essa constatação pode ser atribuída as diferentes condições citadas na Tabela 4.3 para as concentrações de fenol de $600 \mathrm{mg} / \mathrm{L}$, como o tipo de reator (RAHLF), diferente TDH (12 h), diferente meio suporte (matrizes de espuma de poliuretano), além do diferente procedimento adotado para a partida do reator, utilizando a 
glicose como a única fonte de carbono, sendo adicionado posteriormente o fenol, passando a ser única fonte de carbono.

Fang et al. (2006) utilizando reator UASB, tratando água residuária contendo aproximadamente $630 \mathrm{mg} / \mathrm{L}$ de fenol, com TDH de $40 \mathrm{~h}$, a uma temperatura de $55^{\circ} \mathrm{C}$, obteve eficiência média de remoção de fenol de aproximadamente $99 \%$, valor superior ao obtido neste trabalho para a mesma concentração de fenol aplicada na fase VII. Essa constatação pode ser atribuída as diferentes condições aplicadas no estudo realizado por Fang et al. (2006), como o tipo de reator utilizado (UASB), maior valor de TDH (40 h), diferente procedimento adotado para a partida do reator, utilizando fenol como substrato e glicose como co-substrato com TDH de 60 h, diferente composição da água residuária e diferente faixa de temperatura $\left(55^{\circ} \mathrm{C}\right)$, trabalhando em condições termofílicas.

Na fase VIII (700 mg/L de fenol), a eficiência média de remoção de fenol foi de $74,2 \%$.

Fang et al. (2004) utilizando reator UASB, tratando água residuária contendo 700 mg/L de fenol, com TDH de 48 h, obteve eficiência média de remoção de fenol de aproximadamente $100 \%$, valor superior ao obtido neste trabalho para a mesma concentração de fenol aplicada na fase VIII. Essa comprovação pode ser atribuída as diferentes condições aplicadas no estudo realizado por Fang et al. (2004), como o tipo de reator utilizado (UASB), maior valor de TDH (48 h), diferente procedimento adotado para a partida do reator, utilizando fenol como substrato e glicose como co-substrato e diferente composição da água residuária. 


\subsection{Demais parâmetros monitorados}

A Figura 4.5 mostra os resultados obtidos para a variação da DQO afluente e efluente, assim como a eficiência de redução de DQO, para o reator anaeróbio de leito fluidificado.

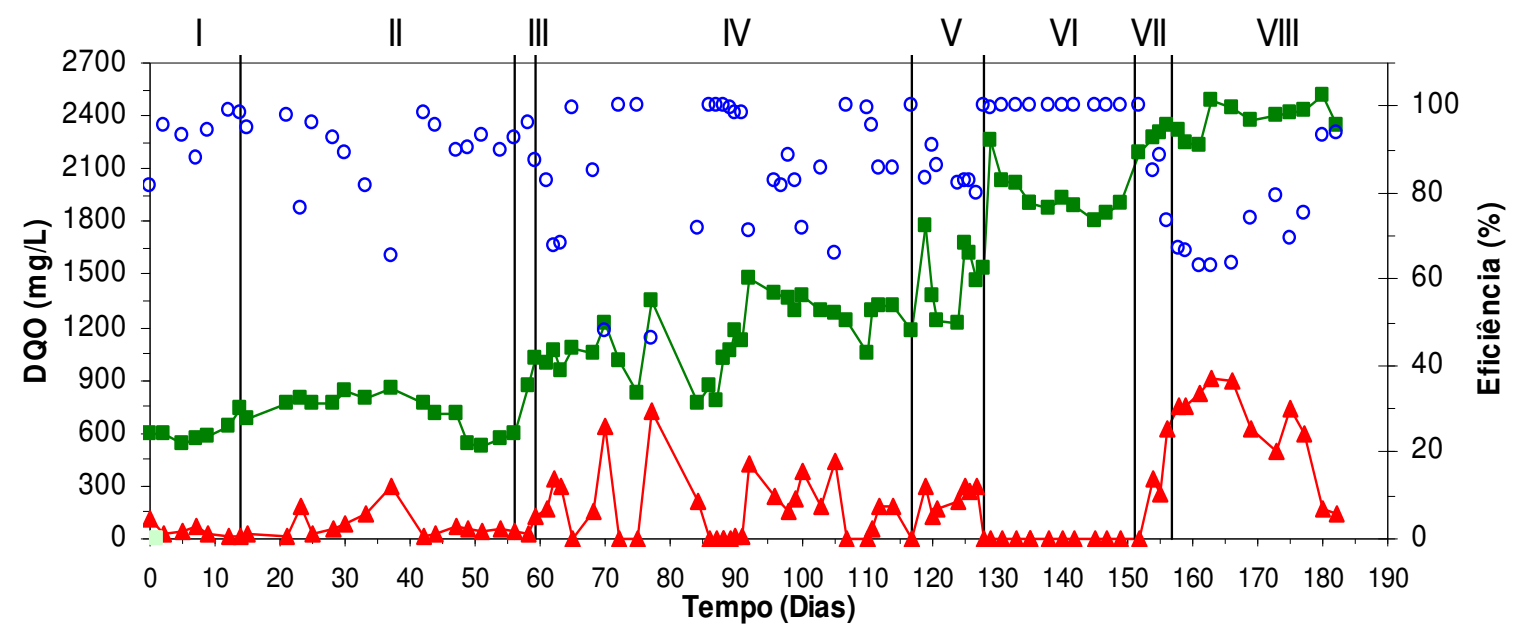

Figura 4.5 - Variação temporal da DQO afluente $\left(-{ }^{-}\right)$, efluente $\left(^{*}\right)$ e eficiência de redução de DQO $\left(^{\circ}\right)$ para o reator anaeróbio de leito fluidificado.

Os resultados obtidos para redução de DQO mostram desempenho satisfatório do reator com o aumento da concentração de fenol alimentado. A eficiência de redução de DQO apresentou o mesmo comportamento que o fenol, com diminuição de desempenho após problemas de sobrecarga na alimentação e quedas de energia. As eficiências médias de redução para cada faixa de concentração de fenol aplicada na alimentação estão expostas na Tabela 4.4. 
Tabela 4.4 - Porcentagem média de DQO removida e seus respectivos desvios para cada concentração de fenol aplicada.

\begin{tabular}{cc}
\hline C fenol $(\mathrm{mg} / \mathrm{L})$ & \% média removida de DQO \\
\hline 50 & $91,9 \pm 6,1$ \\
100 & $90,2 \pm 8,8$ \\
200 & $96 \pm 0$ \\
300 & $81,2 \pm 11,4$ \\
400 & $86,12 \pm 7,6$ \\
500 & $99,9 \pm 0,1$ \\
600 & $86,9 \pm 10,9$ \\
700 & $73,5 \pm 11,3$ \\
\hline
\end{tabular}

Os resultados encontrados neste experimento para a fase I (50 mg/L de fenol) de operação do reator com DQO média afluente de 590 mg/L para eficiência de redução de DQO foi de $91,9 \%$.

O valor obtido por Sancinetti (2004) para redução de DQO durante a operação do RALF com $50 \mathrm{mg} / \mathrm{L}$ de fenol, foi de $70 \%$, resultado inferior ao obtido neste estudo. Essa constatação pode ser atribuída as diferentes condições aplicadas no estudo realizado por Sancinetti (2004), diferente procedimento adotado para a partida do reator, utilizando ensaios em batelada para adaptação do fenol e diferente composição da água residuária, onde a concentração de levedura utilizada para alimentação do sistema, a partir do dia 62 de operação, foi de $0,03 \%$.

Bolaños (2001) obteve eficiência de redução de DQO para a operação do RAHLF com $50 \mathrm{mg} / \mathrm{L}$ de fenol de $82 \%$, valor inferior ao obtido neste estudo. As prováveis explicações para este resultado pode ser atribuído a diferente configuração de reator utilizado por Bolaños 
(2001) (RAHLF), diferente meio suporte (matrizes de espuma de poliuretano), diferente composição da água residuária, diferente procedimento adotado para a parida do sistema e ainda diferente TDH (12 h) empregado.

Durante a fase II (100 mg/L de fenol), a eficiência média de redução de DQO foi de $90,2 \%$.

Nos estudos realizados por Bolaños (2001), Sancinetti (2004) e Sader (2005), a eficiência de redução de DQO para uma concentração de fenol de $100 \mathrm{mg} / \mathrm{L}$ foram de 87\%, $87 \%$ e 78,6\%, respectivamente, valores inferiores aos obtidos neste estudo. As possíveis causas que podem explicar essa constatação seriam as diferentes condições operacionais empregadas, conforme citadas na Tabela 4.3.

A operação do reator na fase III (200 mg/L de fenol) obteve uma eficiência média de redução de DQO de $96 \%$.

Sancinetti (2004) e Sader (2005) obtiveram eficiência de redução de DQO, para a operação do RALF com concentração de fenol de 200 mg/L, 93\% e 88,9\%, respectivamente, valores inferiores aos obtidos neste estudo. Essa constatação pode ser atribuída a pequena duração da fase III (2 dias) neste estudo, conforme citada na Tabela 3.4.

Analisando a fase IV (300 mg/L de fenol) a eficiência de redução de DQO foi de $81,2 \%$.

Nos estudos realizados por Bolaños (2001), Sancinetti (2004) e Sader (2005), a redução de DQO para concentração de fenol de $300 \mathrm{mg} / \mathrm{L}$ foram 98\%, $93 \%$ e 87,1\%, respectivamente, valores superiores ao encontrado neste estudo. A possível explicação pode ser atribuída aos problemas operacionais ocorridos durante a fase IV, conforme citados no item 4.2.1, podendo ter acumulado ácidos orgânicos, prejudicando o desempenho do sistema.

Na fase V (400 mg/L de fenol) de operação do reator, a eficiência de redução de DQO foi de $86,12 \%$. 
Os resultados obtidos por Sancinetti (2004) e Sader (2005) para a redução de DQO com uma água residuária contendo $400 \mathrm{mg} / \mathrm{L}$ de fenol foram 92,6\% e 81\%, respectivamente, resultados superior ao obtido neste estudo. As conseqüências dos problemas operacionais ocorridas durante a operação da fase anterior (fase IV, $300 \mathrm{mg} / \mathrm{L}$ de fenol) podem ter influenciados no desempenho de redução de DQO neste trabalho.

Chang et al. (1995) obtiveram eficiência de redução de DQO, para água residuária contendo $400 \mathrm{mg} / \mathrm{L}$ de fenol, $80 \%$, valor inferior ao encontrado neste estudo. A provável explicação para o diferente valor de redução de DQO pode ser atribuída a diferente configuração do reator utilizado por Chang et al. (1995) (UASB), diferente composição da água residuária, diferentes características do inóculo adotado, diferente TDH (88 a 5,5 h) empregado, além de promover a recirculação do efluente.

Durante a fase VI (500 mg/L de fenol) de operação do reator, a eficiência média de redução de DQO obtida foi em torno de $100 \%$.

Sancinetti (2004) obteve eficiência de redução de DQO para uma concentração de fenol de $500 \mathrm{mg} / \mathrm{L}$ de $88,1 \%$, valor inferior ao obtido neste estudo. As possíveis causas do inferior desempenho de redução de DQO obtido por Sancinetti (2004) podem ser atribuídas a possíveis toxicidades de metais presentes nos componentes da água residuária sintética e também o reator pode ter atingido a capacidade limite de degradação, onde o fenol é um composto tóxico que possui um papel importante no decréscimo da redução de DQO em sistemas de tratamento segundo Kennes et al. (1997).

Na fase VII (600 mg/L de fenol) de operação do reator, obteve-se eficiência média de redução de DQO de $86,9 \%$.

O incremento da concentração de fenol de 500 para $600 \mathrm{mg} / \mathrm{L}$ pode ter causado efeito parcial inibitório da bioatividade dos microrganismos, visto que a eficiência de redução de DQO na fase VII reduziu para $86,9 \%$. 
Durante a fase VIII (700 mg/L de fenol) de operação do reator, a eficiência média de redução de DQO foi de 73,5\%.

Apesar do pH médio na saída estar na faixa adequada de operação, a recuperação da eficiência de redução de DQO foi mais lenta na fase VIII, levando cerca de 20 dias para conseguir atingir cerca de $100 \%$ de redução de DQO. Provavelmente, com a inibição da metanogênese, os ácidos ficaram acumulados no sistema, e para que a DQO na saída diminua as células metanogênicas devem consumir os ácidos presentes no meio e produzir metano, reequilibrando as relações intrínsecas entre as populações presentes no sistema.

Outro parâmetro observado foi o pH no reator, não sendo necessário fazer correção.

A Figura 4.6 mostra os valores medidos para o $\mathrm{pH}$ afluente e efluente do reator anaeróbio de leito fluidificado ao longo do tempo de operação.

Os valores obtidos mostram que o $\mathrm{pH}$ se mantiveram estáveis para todo o sistema, dentro da faixa de operação de sistemas anaeróbios, entre 6,59 e 8,21.

Comparando com as faixas de variação de pH obtidos por Fang et al. (1996), 6,9 a 7,5, Fang e Zhou (1999), 7,5 a 8,0, Bolaños (2001), 7,8 a 8,6, Sancinetti (2004), 6,5 a 8,0, Sader (2005), 6,5 a 8,3, os valores obtidos neste estudo foram semelhantes. 


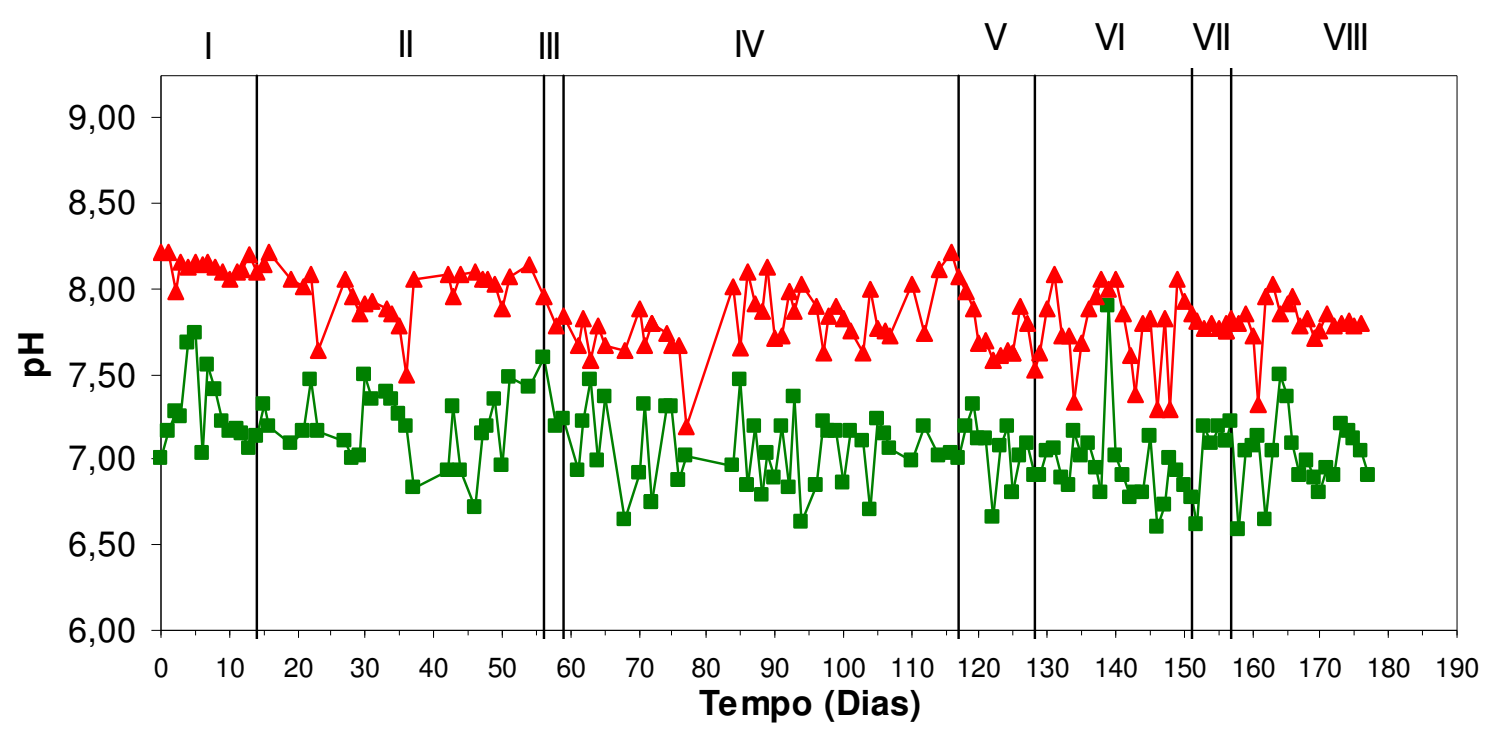

Figura 4.6 - Variação temporal do pH afluente (-) e efluente $\left({ }^{\star}\right)$ para o reator anaeróbio de leito fluidificado.

As variações observadas durante as medidas de $\mathrm{pH}$ podem ser devidas a erros analíticos que não contribuíram de maneira significativa para a interpretação dos resultados. Pode-se dizer que o aumento da concentração de fenol afluente não influenciou no comportamento do $\mathrm{pH}$.

Apesar do fato da exposição da amostra ao ar por alguns minutos pode provocar escape de $\mathrm{CO}_{2}$, causando aumento do $\mathrm{pH}$ (SPEECE, 1996), pode-se dizer que este efeito não foi significativo durante as medidas de $\mathrm{pH}$ durante a operação do reator.

Segundo Speece (1996), a operação de um reator anaeróbio com pH constantemente abaixo de 6,5 ou acima de 8,3 pode ocasionar diminuição significativa da taxa de produção de metano. Durante a operação do reator não foram obtidas medidas de $\mathrm{pH}$ inferiores a 6,5 ou constantemente acima de 8,3.

A Figura 4.7 mostra os resultados obtidos no monitoramento da variação da alcalinidade a bicarbonato para o reator anaeróbio de leito fluidificado operado entre 50 a 700 $\mathrm{mg} / \mathrm{L}$ de fenol. 


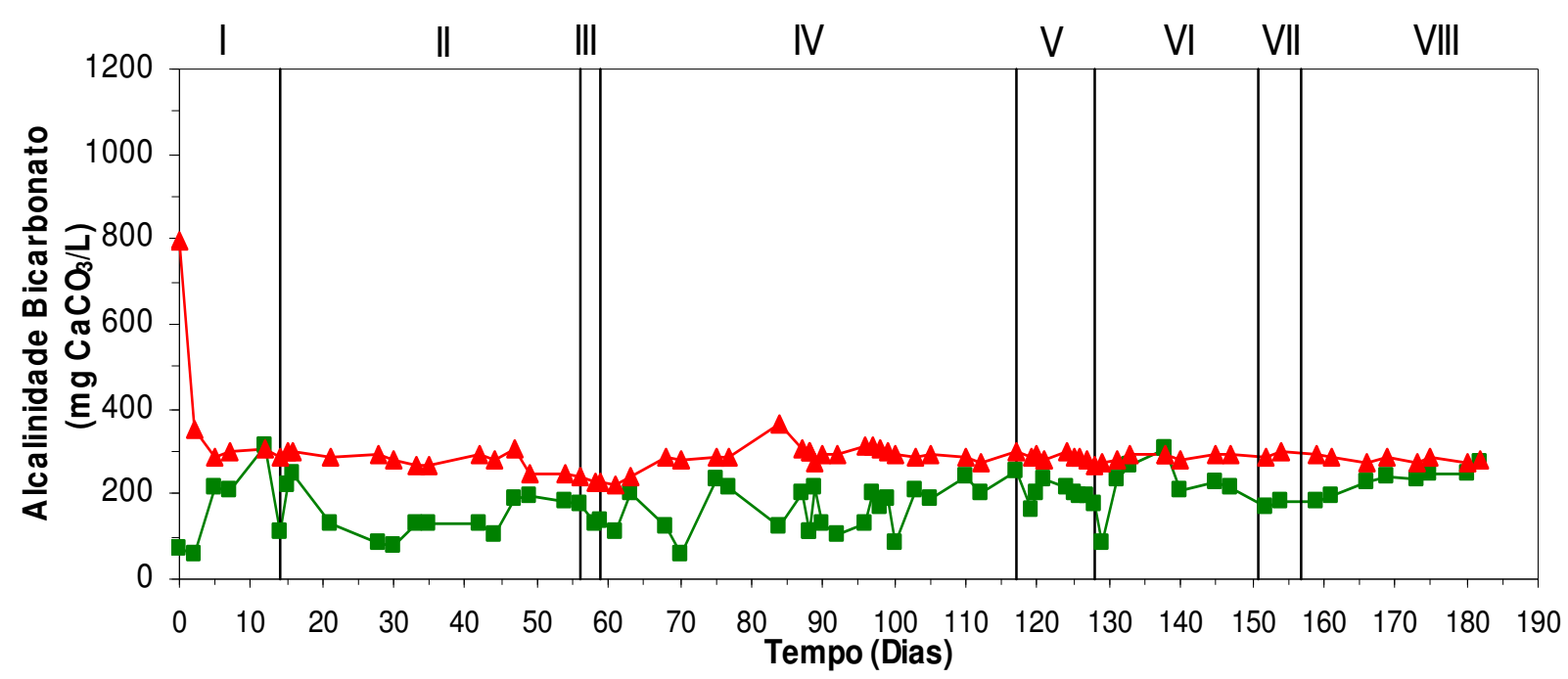

Figura 4.7 - Variação temporal da alcalinidade a bicarbonato afluente $(-)$ e efluente $\left(\star^{-}\right)$para o reator anaeróbio de leito fluidificado.

Os dados obtidos mostram que no início de operação do sistema, houve um aumento na concentração de alcalinidade, a partir do $2^{\circ}$ dia de operação houve uma queda que se manteve durante todo o período de operação, mesmo com os problemas ocasionados. Esse fato pode ser atribuído ao início da operação do reator, quando o sistema ainda não atingiu a estabilidade.

A Tabela 4.5 apresenta os valores médios obtidos para a alcalinidade a bicarbonato no afluente e no efluente do reator anaeróbio de leito fluidificado.

Tabela 4.5 - Valores médios obtidos para alcalinidade a bicarbonato no reator.

\begin{tabular}{ccc}
\hline RALF & Afluente $(\mathrm{mg} / \mathrm{L})$ & Efluente $(\mathrm{mg} / \mathrm{L})$ \\
\hline Poliestireno & $180 \pm 37$ & $294 \pm 9$ \\
\hline
\end{tabular}

Analisando os valores mostrados na Tabela 4.5, pode-se dizer que houve a geração de alcalinidade a bicarbonato, comparando-se os valores afluentes (180 mg/L) e os efluentes 
(294 mg/L) devido a liberação da hidroxila como proposto pela rota metabólica da degradação anaeróbia do fenol que forma o ácido benzóico, conforme mostrado no item 2.2.3. Os valores de alcalinidade a bicarbonato estiveram maiores no efluente do reator, excluindo a ocorrência de acúmulo de ácidos voláteis até o período monitorado, ao contrário de Sader (2005) que obteve valores para alcalinidade a bicarbonato afluente maior que o efluente, $442 \mathrm{mg} / \mathrm{L}$ e 367 mg/L, respectivamente, podendo ser provável o acúmulo de ácidos voláteis. Quando o sistema possui maior alcalinidade o reator tem capacidade de manter o $\mathrm{pH}$ adequado e, consequentemente, a atividade do consórcio microbiano em situações de aumentos inesperados da carga orgânica ou alterações na qualidade do afluente.

Sancinetti (2004) obteve valores maiores, comparados a este estudo, de alcalinidade a bicarbonato afluente e efluente, operando entre 50 a $400 \mathrm{mg} / \mathrm{L}$ de fenol, 360,48 mg/L e 451,82 $\mathrm{mg} / \mathrm{L}$, respectivamente.

A Figura 4.8 mostra os resultados obtidos no monitoramento da variação de ácidos voláteis totais para o reator anaeróbio de leito fluidificado.

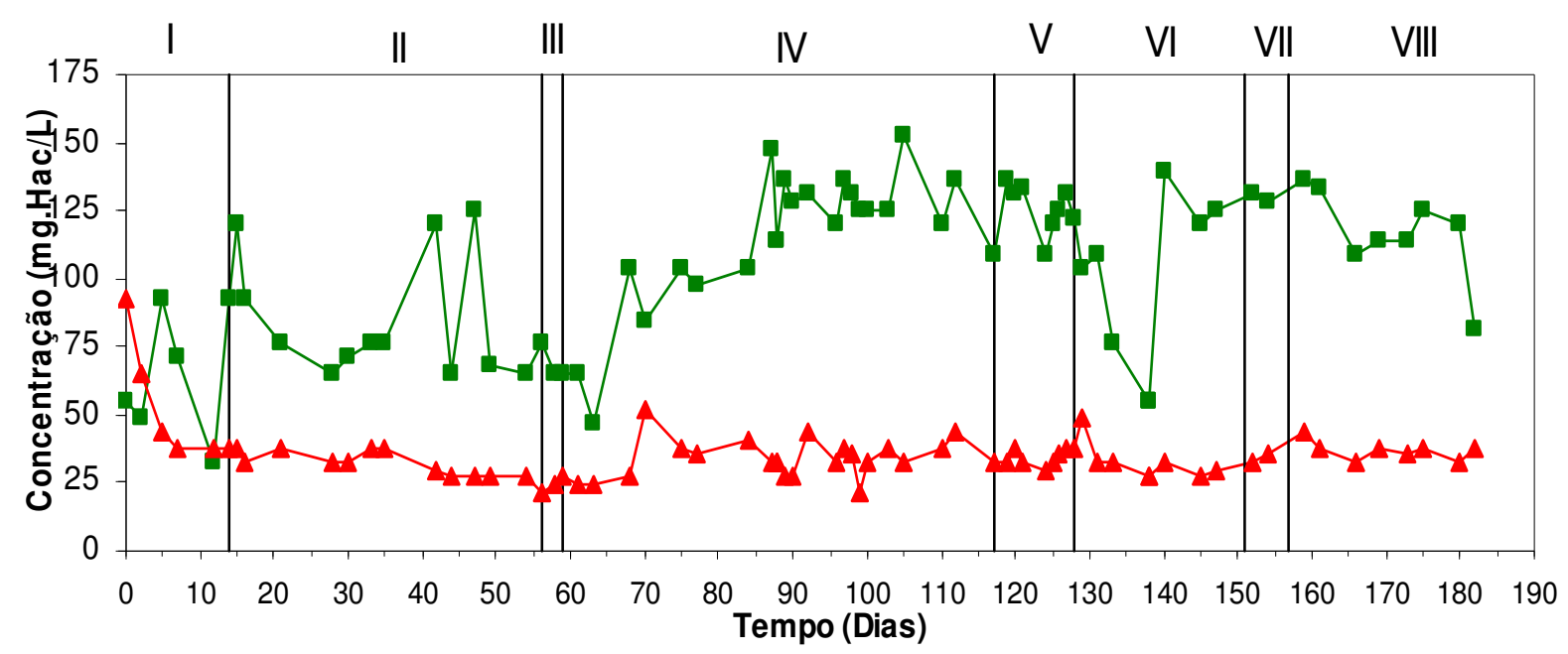

Figura 4.8 - Variação temporal dos ácidos voláteis totais afluente $\left({ }^{-}\right)$e efluente $\left(^{\star}\right)$ para 0 reator anaeróbio de leito fluidificado. 
Os dados obtidos mostram que no início de operação do sistema, a quantidade de ácidos voláteis totais detectados no efluente foi maior que a do afluente, a partir do $5^{\circ}$ dia de operação houve uma queda que se manteve estável durante todo o período de operação, mesmo com os problemas ocasionados. Essa constatação pode ser atribuída ao possível acúmulo de ácidos orgânicos e ainda o sistema pôde não ter atingido a estabilidade, pois o sistema ainda encontrava-se na fase inicial de operação.

Os valores do pH efluente no RALF variou entre 7,19 a 8,21 (ver Figura 4.6), estando dentro da faixa ótima citada por Speece (1996). A possível razão para a estabilidade nos valores de $\mathrm{pH}$ pode ter sido pela estabilidade dos valores de AVT conforme mostrado na Figura 4.8. A concentração média dos AVT no RALF foi de $104 \mathrm{mg} / \mathrm{L}$ para todas as concentrações de fenol aplicadas (entre 50 a 700 mg/L). A concentração média efluente dos AVT foi de $35 \mathrm{mg} / \mathrm{L}$, provando que o sistema removeu os AVT. Em altas TCO o efeito de toxicidade da água residuária e dos produtos intermediários podem causar pré-acidificação resultando na acumulação de DQO (LETTINGA et al., 1984). A DQO que foi originada desses substratos não pode ser convertida a metano, resultando no acúmulo de AVT.

A Tabela 4.6 apresenta os valores médios obtidos para os ácidos voláteis totais no afluente e no efluente do reator anaeróbio de leito fluidificado.

Tabela 4.6 - Valores médios obtidos para ácidos voláteis totais no reator.

\begin{tabular}{ccc}
\hline RALF & Afluente $(\mathrm{mg} / \mathrm{L})$ & Efluente $(\mathrm{mg} / \mathrm{L})$ \\
\hline Poliestireno & $104 \pm 16$ & $35 \pm 6$ \\
\hline
\end{tabular}

Analisando os valores pode-se dizer que houve uma redução no acúmulo de ácidos voláteis totais, comparando-se os afluentes e os efluentes. Os valores de ácidos voláteis totais 
estiveram maiores no afluente do reator, constatando a estabilização do processo de digestão anaeróbia no reator.

No estudo realizado por Bolaños (2001) não foram detectados ácidos voláteis por titulação e concentrações mensuráveis por cromatografia durante a operação do reator anaeróbio horizontal de leito fixo durante a degradação de fenol em todas as fases de operação para concentrações de fenol de 50,2 até $1203 \mathrm{mg} / \mathrm{L}$.

Segundo estudo realizado por Sancinetti (2004), os ácidos voláteis foram detectados por cromatografia somente durante a operação do reator anaeróbio de leito fluidificado com concentrações de $400 \mathrm{mg} / \mathrm{L}$ de fenol.

Neste estudo, foi verificada a presença em pequenas concentrações de ácidos voláteis por titulação, desde o início da operação do reator. Essa constatação pode ser atribuída a imprecisão do método utilizado para determinar ácidos voláteis no sistema.

Os ácidos voláteis foram detectados por cromatografia somente durante a operação do reator com concentração de $300 \mathrm{mg} / \mathrm{L}$, na fase IV, porém na fase I (50 mg/L de fenol) no dia zero de operação foi detectado concentração traço de ácido butírico e durante a fase II (100 $\mathrm{mg} / \mathrm{L}$ de fenol) no $23^{\circ}$ dia de operação foram detectados $17,55 \mathrm{mg} / \mathrm{L}$ de ácido acético, 0,50 $\mathrm{mg} / \mathrm{L}$ de ácido isobutírico e 5,55 mg/L de ácido isovalérico. No dia $70^{\circ}$ dia de operação, na fase IV, foram detectados $0,85 \mathrm{mg} / \mathrm{L}$ de ácido isobutírico e 4,49 $\mathrm{mg} / \mathrm{L}$ de ácido isovalérico, no $77^{\circ}$ dia de operação, fase IV, foram obtidos 41,51 mg/L de ácido acético, 8,24 mg/L de ácido propiônico, 5,69 mg/L de ácido isobutírico, 12,84 mg/L de ácido isovalérico e 0,55 de ácido valérico, no $105^{\circ}$ dia de operação, fase IV, foram detectados $4,19 \mathrm{mg} / \mathrm{L}$ de ácido acético e 0,98 mg/L de ácido butírico, no $128^{\circ}$ dia de operação, fase $\mathrm{V}$, foram detectados 9,42 mg/L de ácido acético, 0,82 mg/L de ácido isobutírico, $1,31 \mathrm{mg} / \mathrm{L}$ de ácido butírico e 0,99 mg/L de ácido isovalérico. No $129^{\circ}$ dia de operação, fase VI, foram detectados $13,85 \mathrm{mg} / \mathrm{L}$ de ácido acético, 0,59 mg/L de ácido isobutírico e $0,80 \mathrm{mg} / \mathrm{L}$ de ácido isovalérico, no $140^{\circ}$ dia de 
operação, fase VI, foi detectado $2,81 \mathrm{mg} / \mathrm{L}$ de ácido acético. A presença de ácidos voláteis como acético, propiônico, isobutírico, butírico, isovalérico, valérico, poderia confirmar a rota redutiva conforme citada no item 2.2.3.3.

A constatação da presença de ácidos voláteis no $23^{\circ}, 70^{\circ}$ e $77^{\circ}$ dia comprova os resultados obtidos de concentração de fenol que indicaria queda da eficiência do reator para $77,5 \%, 23,6 \%$ e $40 \%$. Durante os dias 105, 128, 129 e 140 a presença de ácidos voláteis pode ter ocorrido devido às falhas na vazão de alimentação, aumento da carga orgânica, e quedas de energia, prejudicando a eficiência do sistema. A análise realizada no dia seguinte após a diminuição da eficiência, não indicou presença de ácidos voláteis, comprovando a recuperação do reator e a estabilidade do sistema. A Tabela 4.7 mostra a presença de ácidos voláteis durante a operação do reator anaeróbio de leito fluidificado.

Tabela 4.7 - Ácidos voláteis detectados via cromatografia gasosa durante a operação do reator anaeróbio de leito fluidificado.

\begin{tabular}{|c|c|c|c|c|c|c|c|c|}
\hline $\begin{array}{c}\text { Dia de } \\
\text { operação }\end{array}$ & $\begin{array}{l}\text { Con.Fenol } \\
(\mathrm{mg} / \mathrm{L})\end{array}$ & $\begin{array}{l}\text { Acético } \\
(\mathrm{mg} / \mathrm{L})\end{array}$ & $\begin{array}{c}\text { Propiônico } \\
\text { (mg/L) }\end{array}$ & $\begin{array}{l}\text { Isobutírico } \\
(\mathrm{mg} / \mathrm{L})\end{array}$ & $\begin{array}{l}\text { Butírico } \\
(\mathrm{mg} / \mathrm{L})\end{array}$ & $\begin{array}{c}\text { Isovalérico } \\
(\mathrm{mg} / \mathrm{L})\end{array}$ & $\begin{array}{c}\text { Valérico } \\
(\mathrm{mg} / \mathrm{L})\end{array}$ & $\begin{array}{c}\text { Capróico } \\
(\mathrm{mg} / \mathrm{L})\end{array}$ \\
\hline 0 & 50 & 0,00 & 0,00 & 0,00 & 0,53 & 0,00 & 0,00 & 0,00 \\
\hline 23 & 100 & 17,55 & 0,00 & 0,50 & 0,00 & 5,55 & 0,00 & 0,00 \\
\hline 70 & 300 & 0,00 & 0,00 & 0,85 & 0,00 & 4,48 & 0,00 & 0,00 \\
\hline 77 & 300 & 41,50 & 8,24 & 5,69 & 5,80 & 12,83 & 0,55 & 0,00 \\
\hline 105 & 300 & 4,19 & 0,00 & 0,00 & 0,97 & 0,00 & 0,00 & 0,00 \\
\hline 128 & 400 & 9,42 & 0,00 & 0,82 & 1,30 & 0,99 & 0,00 & 0,00 \\
\hline 129 & 500 & 13,85 & 0,00 & 0,58 & 0,00 & 0,80 & 0,00 & 0,00 \\
\hline 140 & 500 & 2,81 & 0,00 & 0,00 & 0,00 & 0,00 & 0,00 & 0,00 \\
\hline \multicolumn{2}{|c|}{ Limite detectável } & 3,70 & 0,65 & 0,39 & 0,37 & 0,37 & 0,47 & 0,47 \\
\hline
\end{tabular}




\subsection{Efeito do aumento progressivo da carga orgânica}

As Figuras 4.9 e 4.10 mostram os resultados obtidos no monitoramento da Taxa de Carregamento Orgânico (TCO) relacionada ao fenol para o reator anaeróbio de leito fluidificado.

Na Figura 4.9, podemos observar que os valores aplicados da TCO coincidem com os valores da TCO removida, exceto durante a fase IV, onde ocorreram problemas operacionais devido a quedas sucessivas de energia e aumento da carga orgânica inesperada devido ao aumento da vazão da bomba de alimentação do sistema. Essa constatação pode ser atribuída a estabilidade do $\mathrm{pH}$, mantendo-se na faixa considerada por Speece (1996), o consumo de ácidos voláteis, conforme mostrado na Figura 4.8, produção de alcalinidade a bicarbonato, conforme mostrado na Figura 4.7, fazendo com que a rota de degradação anaeróbia do fenol não sofresse choques devido as possíveis alterações dos parâmetros monitorados no sistema.

Durante a fase VIII, também podemos observar que no início a eficiência de remoção da TCO aplicada foi menor que nas outras fases, podendo ser causada pela toxicidade dos produtos intermediários formados na degradação anaeróbia do fenol, e também pelo provável acúmulo de ácidos no reator, causando desequilíbrio no sistema, porém nos últimos dias de operação do RALF, pôde-se observar o aumento no desempenho de remoção de fenol no sistema, o que pode ser devido à adaptação da biomassa presente no sistema. A eficiência média de remoção da carga orgânica aplicada de fenol no RALF foi de 90\%, sua variação está apresentada na Figura 4.10. 


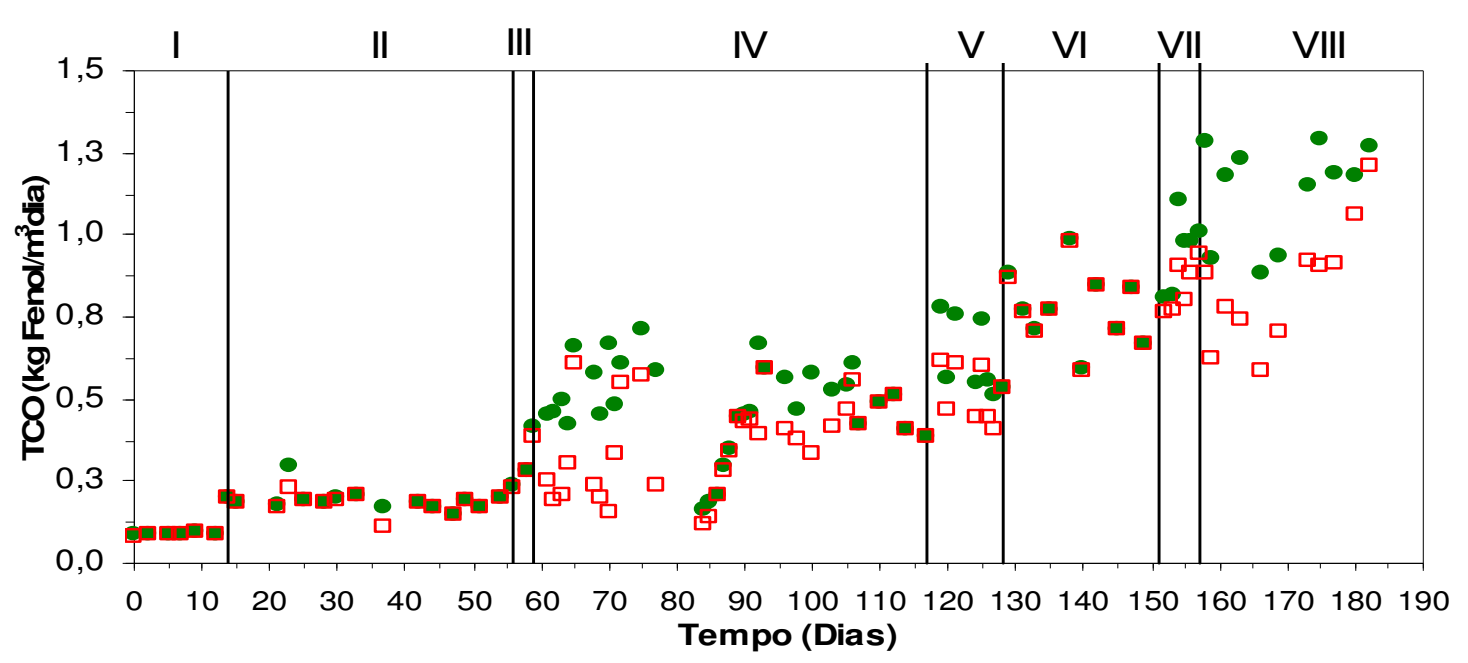

Figura 4.9 - Variação temporal da Taxa de Carregamento Orgânico Aplicada (•) e Removida (ㅁ) relacionada ao fenol para o reator anaeróbio de leito fluidificado.

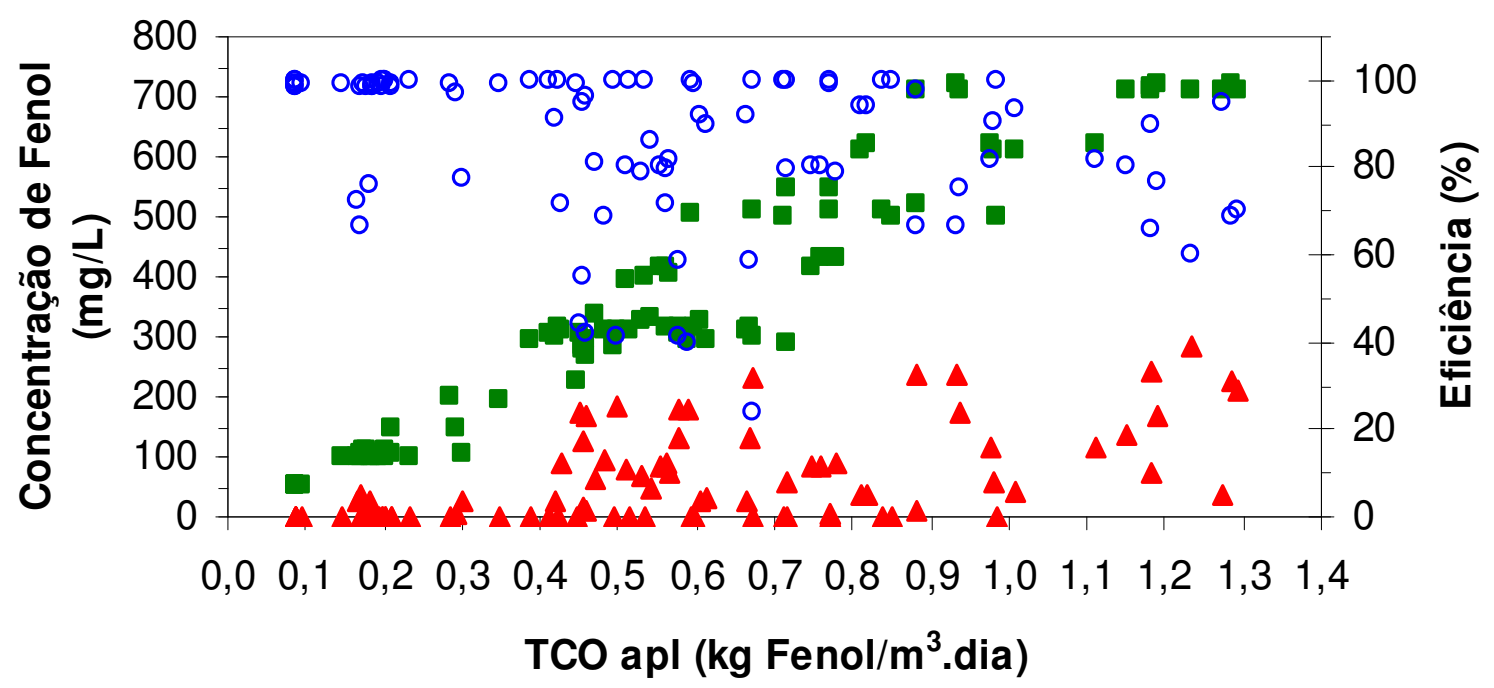

Figura 4.10 - Efeito da carga orgânica de fenol aplicada em relação à concentração de fenol afluente $(-)$, efluente $\left({ }^{\star}\right)$ e a eficiência de remoção de fenol $\left(^{\circ}\right)$ para o reator anaeróbio de leito fluidificado.

Chang et al. (1995) utilizando reator UASB tratando água residuária contendo uma carga aplicada de fenol variando entre 0,1 a $2,2 \mathrm{~kg}$ fenol $/ \mathrm{m}^{3} \mathrm{~d}$, obteve eficiência de remoção de carga aplicada de fenol de 50\%, porém promovendo a recirculação do efluente a eficiência 
aumentou para 90\%, valor semelhante ao obtido neste estudo. Essa constatação pode ser atribuída a opção pela recirculação do efluente adotada por Chang et al. (1995), aumentando a eficiência do sistema.

Fang et al. (1996) utilizando reator UASB tratando água residuária contendo uma carga aplicada de fenol variando de 0,42 a $2,52 \mathrm{~kg}$ fenol $/ \mathrm{m}^{3} \mathrm{~d}$, obteve eficiência de remoção de carga aplicada de fenol de 97\%, valor superior ao encontrado neste estudo. A principal causa que pode ser apontada como responsável por essa constatação seria a opção pela recirculação do efluente adotado por Fang et al. (1996).

A eficiência média obtida por Fang e Zhou (1999) utilizando reator UASB, tratando água residuária contendo uma carga aplicada de fenol de $0,2 \mathrm{~kg} \mathrm{fenol} / \mathrm{m}^{3} \mathrm{~d}$, obteve eficiência de remoção de carga orgânica aplicada de $98 \%$, valor superior ao obtido neste estudo. O principal fator que pode ser atribuído seria a diferente configuração do reator (UASB) utilizado por Fang e Zhou (1999).

Bolaños (2001) utilizando reator RAHLF, tratando água residuária contendo carga aplicada de fenol variando entre 0,1 a $2,4 \mathrm{~kg}$ fenol $/ \mathrm{m}^{3} \mathrm{~d}$, obteve eficiência média de remoção de carga de fenol aplicada de $98 \%$, valor superior ao obtido neste estudo. As possíveis causas para esta constatação que podem ser apontadas são a diferente configuração de reator (RAHLF) utilizado por Bolaños (2001), diferente meio suporte para adesão microbiana e diferente inóculo empregado.

Sancinetti (2004) e Sader (2005) utilizaram reator RALF sobre carga orgânica de fenol variando entre 0,09 a $0,9 \mathrm{~kg}$ fenol $/ \mathrm{m}^{3} \mathrm{~d}$ e 0,09 a $0,324 \mathrm{~kg}$ fenol $/ \mathrm{m}^{3} \mathrm{~d}$, respectivamente, obtiveram eficiência de remoção de carga orgânica aplicada de fenol de 95\% e 96,75\%, respectivamente, valores superiores ao obtido neste estudo. Essa constatação pode ser atribuída as menores taxas de carregamento orgânico de fenol aplicado no sistema. 
O efeito da carga orgânica de fenol na eficiência de redução de DQO é apresentado na Figura 4.11. A DQO afluente variou de $531 \mathrm{mg} / \mathrm{L}$ a $2519 \mathrm{mg} / \mathrm{L}$. A eficiência média de redução de DQO foi de $92 \%$ durante a operação do reator com taxa de carregamento orgânico (TCO) média de $0,09 \mathrm{~kg}$ fenol $/ \mathrm{m}^{3}$ dia. A TCO média foi aumentada para $0,20 \mathrm{~kg}$ fenol $/ \mathrm{m}^{3}$ dia a eficiência média de redução de DQO reduziu para 90\%. Quando a TCO média foi aumentada para $0,28 \mathrm{~kg}$ fenol $/ \mathrm{m}^{3}$ dia a eficiência de redução de DQO passou para $96 \%$. Para o incremento da TCO média de $0,55 \mathrm{~kg}$ fenol $/ \mathrm{m}^{3}$ dia, $0,63 \mathrm{~kg}$ fenol $/ \mathrm{m}^{3} \mathrm{dia}, 0,78 \mathrm{~kg}$ fenol $/ \mathrm{m}^{3} \mathrm{dia}, 0,95 \mathrm{~kg}$ fenol $/ \mathrm{m}^{3}$ dia e $1,14 \mathrm{~kg}$ fenol $/ \mathrm{m}^{3}$ dia as eficiências médias de redução de DQO foram de $81 \%$, $86 \%, 100 \%, 87 \%$ e $74 \%$, respectivamente. A eficiência de redução de DQO exibiu um bom desempenho $(E=88 \%)$ para as taxas de carregamento orgânico de 0,09 a $1,29 \mathrm{~kg}$ fenol $/ \mathrm{m}^{3} \mathrm{dia}$.

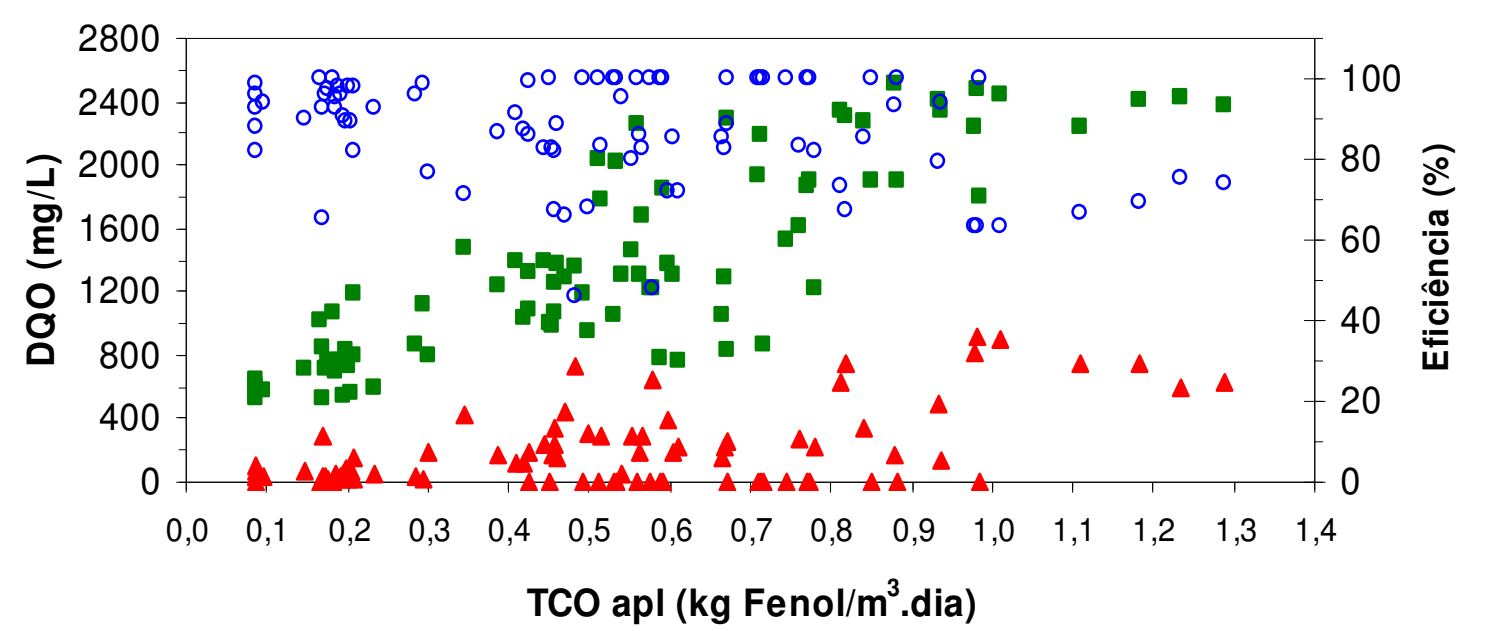

Figura 4.11 - Variação da Taxa de Carregamento Orgânico Aplicada relacionada ao fenol com a DQO afluente $(-)$ e efluente $\left({ }^{\star}\right)$ e a eficiência de redução de DQO $\left(^{\circ}\right)$ para o reator anaeróbio de leito fluidificado.

O efeito da taxa de carregamento orgânico relacionada a DQO na eficiência de remoção de fenol é apresentado na Figura 4.12. A eficiência média de remoção de fenol foi de 99\% durante a operação do reator com taxa de carregamento orgânico (TCO) média de 1,01 
$\mathrm{kg}$ DQO $/ \mathrm{m}^{3}$ dia. A TCO média foi aumentada para $1,34 \mathrm{~kg} \mathrm{DQO} / \mathrm{m}^{3}$ dia a eficiência média de remoção de fenol reduziu para $96 \%$. Quando a TCO média foi aumentada para 1,43 kg DQO/ $\mathrm{m}^{3}$ dia a eficiência de remoção de fenol passou para $99 \%$. Para o incremento da TCO média de 2,38 kg DQO $/ \mathrm{m}^{3} \mathrm{dia}, 2,14 \mathrm{~kg}$ DQO $/ \mathrm{m}^{3}$ dia, 2,99 kg DQO $/ \mathrm{m}^{3} \mathrm{dia}, 3,59 \mathrm{~kg}$ DQO$/ \mathrm{m}^{3}$ dia e 3,81 kg $\mathrm{DQO} / \mathrm{m}^{3}$ dia as eficiências médias de remoção de fenol foram de $81 \%, 83 \%, 99 \%, 89 \%$ e $74 \%$, respectivamente. A eficiência de remoção de fenol exibiu uma satisfatória performance $(\mathrm{E}=$ 90\%) para as taxas de carregamento orgânico de 0,90 a 4,39 $\mathrm{kg} \mathrm{DQO} / \mathrm{m}^{3}$ dia. A redução da eficiência de remoção de fenol para $74 \%$ pode ser atribuída ao possível acúmulo de ácidos voláteis no reator, causando o desequilíbrio do sistema, podendo ter modificado a rota metabólica de degradação anaeróbia de fenol, ou ainda o sistema pode não ter tido tempo suficiente para que a biomassa se adaptasse a carga orgânica média de fenol aplicada de 1,14 $\mathrm{kg}$ fenol $/ \mathrm{m}^{3}$ dia correspondendo a concentração de fenol de $700 \mathrm{mg} / \mathrm{L}$, e ainda pôde ter causado um efeito inibitório devido ao aumento da concentração de fenol para $700 \mathrm{mg} / \mathrm{L}$. 


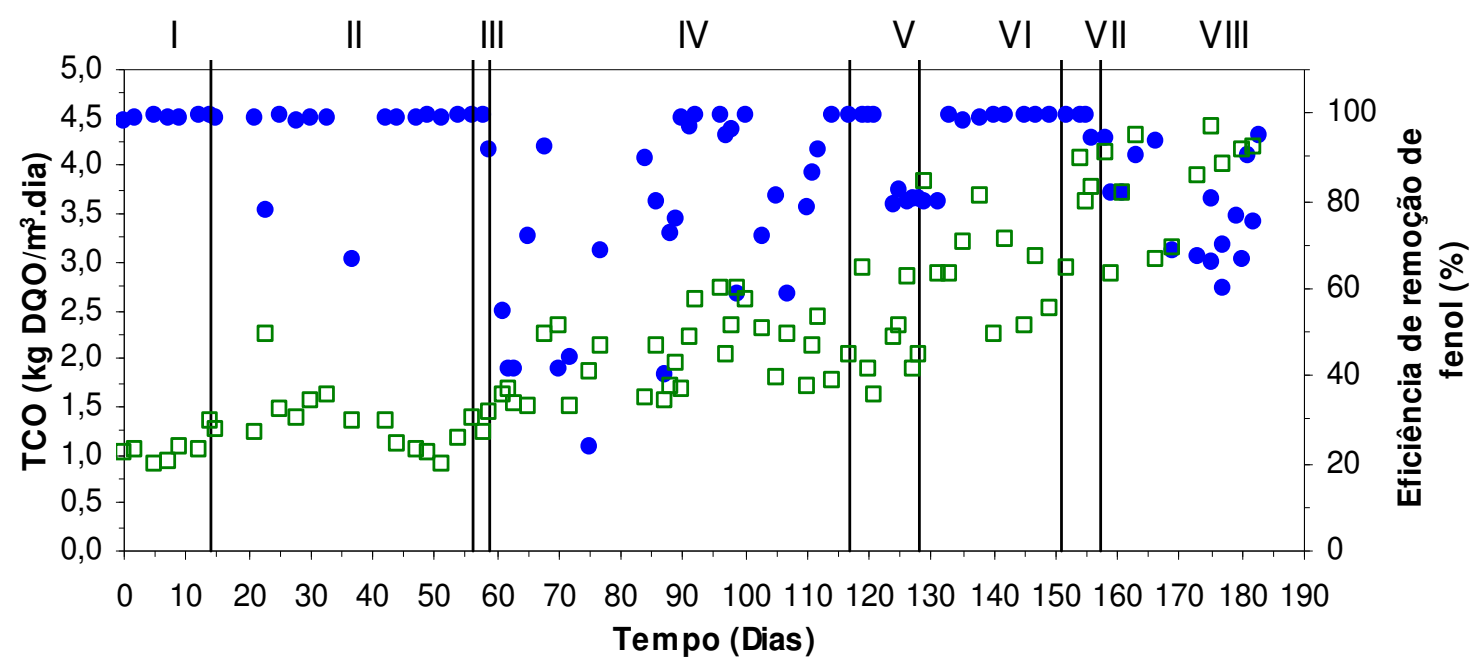

Figura 4.12 - Variação temporal da Taxa de Carregamento Orgânico Aplicada () relacionada a DQO e eficiência de remoção de fenol $(\bullet)$ para o reator anaeróbio de leito fluidificado.

A Tabela 4.8 apresenta os valores médios e desvios obtidos para os parâmetros monitorados durante a operação do reator. 
Tabela 4.8 - Valores médios para os parâmetros monitorados durante as fases I a VIII.

\begin{tabular}{|c|c|c|c|c|c|c|c|c|}
\hline & I & II & III & IV & $\mathrm{V}$ & VI & VII & VIII \\
\hline $\mathrm{pH}$ afluente & $7,28 \pm 0,23$ & $7,20 \pm 0,21$ & $7,20 \pm 0,00$ & $7,04 \pm 0,22$ & $7,02 \pm 0,19$ & $6,97 \pm 0,25$ & $7,03 \pm 0,24$ & $7,00 \pm 0,20$ \\
\hline $\mathrm{pH}$ efluente & $8,13 \pm 0,06$ & $7,98 \pm 0,16$ & $7,78 \pm 0,00$ & $7,83 \pm 0,13$ & $7,69 \pm 0,12$ & $7,77 \pm 0,25$ & $7,79 \pm 0,04$ & $7,80 \pm 0,13$ \\
\hline Fenol afluente $[\mathrm{mg} / \mathrm{L}]$ & $52 \pm 1$ & $105 \pm 5$ & $201 \pm 0$ & $314 \pm 22$ & $415 \pm 14$ & $515 \pm 18$ & $615 \pm 6$ & $713 \pm 5$ \\
\hline Fenol efluente $[\mathrm{mg} / \mathrm{L}]$ & $1 \pm 0$ & $3 \pm 10$ & $1 \pm 0$ & $59 \pm 47$ & $72,8 \pm 29,5$ & $3,3 \pm 2,7$ & $66,1 \pm 38$ & $184 \pm 73$ \\
\hline Remoção de fenol [\%] & $98,9 \pm 0,6$ & $95,6 \pm 9,4$ & $99,3 \pm 0,00$ & $80,6 \pm 15,5$ & $82,6 \pm 7,0$ & $99,4 \pm 0,5$ & $89,3 \pm 6,1$ & $74,2 \pm 10,7$ \\
\hline DQO afluente [mg/L] & $590 \pm 37$ & $715 \pm 103$ & $870 \pm 0$ & $1303 \pm 116$ & $1490 \pm 309$ & $1947 \pm 145$ & $2278 \pm 56$ & $2382 \pm 92$ \\
\hline DQO efluente $[\mathrm{mg} / \mathrm{L}]$ & $48 \pm 36$ & $73 \pm 75$ & $35 \pm 0$ & $228 \pm 156$ & $207 \pm 115$ & $0,32 \pm 1,05$ & $394 \pm 299$ & $614 \pm 264$ \\
\hline Redução de DQO [\%] & $91,9 \pm 6,1$ & $90,2 \pm 8,8$ & $96,0 \pm 0,0$ & $81,2 \pm 11,4$ & $86,12 \pm 7,6$ & $99,9 \pm 0,1$ & $86,9 \pm 10,9$ & $73,5 \pm 11,2$ \\
\hline TCO afluente $\left[\mathrm{kg}\right.$ fenol $\left./ \mathrm{m}^{3} \mathrm{dia}\right]$ & $0,09 \pm 0,00$ & $0,20 \pm 0,03$ & $0,28 \pm 0,00$ & $0,55 \pm 0,07$ & $0,63 \pm 0,11$ & $0,78 \pm 0,11$ & $0,95 \pm 0,12$ & $1,14 \pm 0,15$ \\
\hline TCO efluente $\left[\mathrm{kg}\right.$ fenol $\left./ \mathrm{m}^{3} \mathrm{dia}\right]$ & $0,09 \pm 0,00$ & $0,19 \pm 0,03$ & $0,28 \pm 0,00$ & $0,44 \pm 0,08$ & $0,51 \pm 0,08$ & $0,77 \pm 0,11$ & $0,84 \pm 0,08$ & $0,85 \pm 0,19$ \\
\hline TCO afluente $\left[\mathrm{kg}\right.$ DQO $\left./ \mathrm{m}^{3} \mathrm{dia}\right]$ & $1,01 \pm 0,07$ & $1,34 \pm 0,31$ & $1,43 \pm 0,00$ & $2,38 \pm 0,32$ & $2,14 \pm 0,41$ & $2,99 \pm 0,52$ & $3,59 \pm 0,49$ & $3,81 \pm 0,54$ \\
\hline TCO efluente $\left[\mathrm{kg} \mathrm{DQO} / \mathrm{m}^{3} \mathrm{dia}\right]$ & $0,93 \pm 0,11$ & $1,19 \pm 0,23$ & $1,26 \pm 0,00$ & $1,93 \pm 0,35$ & $1,89 \pm 0,32$ & $2,99 \pm 0,52$ & $3,09 \pm 0,31$ & $2,82 \pm 0,68$ \\
\hline Ácidos Voláteis Totais [mg/L] & $56 \pm 24$ & $32 \pm 5$ & $25 \pm 0$ & $33 \pm 5$ & $34 \pm 3$ & $34 \pm 7$ & $31 \pm 2$ & $37 \pm 3$ \\
\hline Alcalinidade $[\mathrm{mg} / \mathrm{L}]$ & $407 \pm 219$ & $279 \pm 20$ & $228 \pm 0$ & $301 \pm 10$ & $289 \pm 8$ & $285 \pm 11$ & $291 \pm 5$ & $284 \pm 9$ \\
\hline
\end{tabular}




\subsection{Produção e análise da formação do biogás}

As análises do biogás para verificar a presença de metano no reator foram realizadas durante a fase VIII (700 mg/L de Fenol), visto que Sancinetti (2004) não detectou a formação de metano após a degradação do fenol pelo sistema de deslocamento de líquido durante a operação do reator anaeróbio de leito fluidificado com 50 a 500 mg/L de fenol. Possivelmente, a quantidade de metano produzida foi pequena, pelo fato do reator estar operando com baixas concentrações de matéria orgânica e tempo de detenção hidráulica de 24 horas, ou ainda podem ter ocorridos perdas, apesar do reator ter sido operado de maneira cuidadosa. A garantia de que o fenol estava sendo completamente degradado a $\mathrm{CO}_{2}$ e $\mathrm{CH}_{4}$ pode ser atribuída ao fato de não terem sido obtidas quantidades mensuráveis de ácidos voláteis no efluente por cromatografia e a ocorrência de remoção completa de fenol e redução de DQO acima de $90 \%$.

Bolaños (2001) obteve medidas de formação de metano somente para concentrações de fenol acima de $634 \mathrm{mg} / \mathrm{L}$ durante a operação do RAHLF.

A concentração média de $\mathrm{CH}_{4}$ encontrada no reator anaeróbio de leito fluidificado foi de $1,58.10^{-4} \mathrm{mmol} / \mathrm{mL}$.

A Figura 4.13 mostra a produção de biogás para o reator anaeróbio de leito fluidificado, que variou de 1354 a 3948 mL/dia, onde a produção média de biogás formado foi de $2362 \mathrm{~mL} / \mathrm{dia}$. 


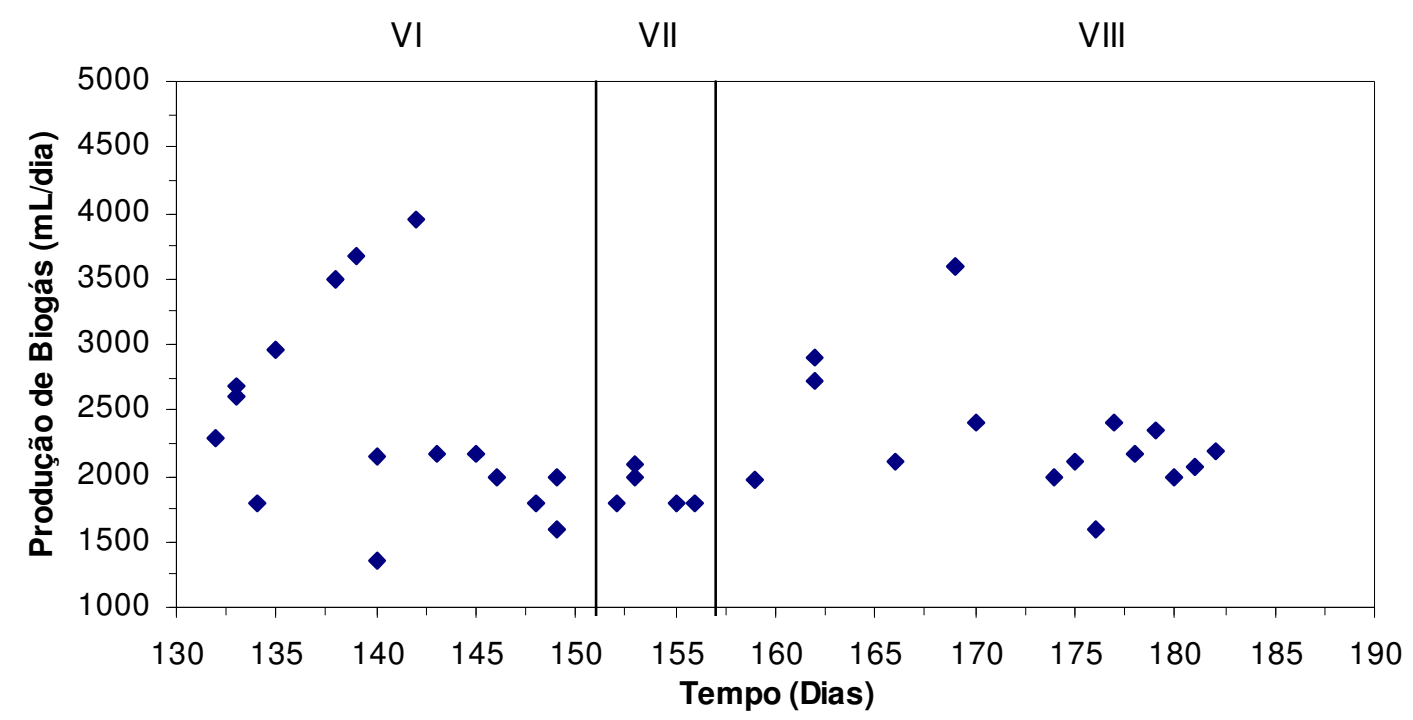

Figura 4.13 - Variação temporal da produção do biogás no reator anaeróbio de leito fluidificado.

Hwang e Cheng (1991a) operando reator UASB de 21,3 L a $35^{\circ} \mathrm{C}$, com TDH de aproximadamente 24 h, para o tratamento de água residuária sintética contendo concentrações entre 1000 a $3000 \mathrm{mg} / \mathrm{L}$ de $p$-cresol, produziu biogás variando entre 25,7 a $79 \mathrm{~L} / \mathrm{d}$, faixa superior ao encontrado neste estudo. Ainda Hwang e Cheng (1991b) operando o mesmo reator, porém modificando o composto fenólico, utilizando o catecol a uma concentração de $1000 \mathrm{mg} / \mathrm{L}$ produziu biogás entre 29,6 a 71,8 L/d, valor superior ao encontrado neste estudo. As possíveis causas para essa constatação seriam a diferente configuração do reator (UASB), além do seu volume total (21,3 L) ser superior ao volume do RALF (4,2 L) utilizado neste estudo, a diferente fonte de carbono, utilizando o $p$-cresol e o catecol.

Cheng et al. (1991) operando RALF de 35,4 L a 35 C, com TDH variando de 48 a 20 h, para tratar água residuária contendo 200 a 3000 mg/L de fenol utilizando carvão ativado granular como meio suporte, produziu biogás variando entre 28,9 a $116 \mathrm{~L} / \mathrm{d}$, faixa superior ao encontrado neste estudo. Essa constatação pode ser atribuída ao maior volume do reator, 
concentrações superiores de fenol afluente, diferente TDH, variando de 48 a 20 h e diferente meio suporte utilizado para adesão microbiana (carvão ativado granular).

Razo-Flores et al. (2003), operando reator UASB de $0,16 \mathrm{~L}$ a $30^{\circ} \mathrm{C}$, com TDH variando de 0,5 a 0,6 d, para o tratamento de água residuária sintética contendo mistura de compostos fenólicos (800 mg/L de fenol e $400 \mathrm{mg} / \mathrm{L}$ de $p$-cresol), produziu biogás variando entre $0,454 \mathrm{~L} / \mathrm{d}$, faixa inferior ao obtido neste estudo. Essa constatação pode ser atribuída a diferente configuração do reator (UASB) com volume total $(0,16 \mathrm{~L})$ inferior ao RALF $(4,2 \mathrm{~L})$ utilizado neste estudo, diferente composição da água residuária sintética, contendo fenol e $p$ cresol, diferente TDH (0,5 a 0,6 d) e diferente inóculo (mistura de lodo granular obtido de dois reatores UASB que trataram despejos industriais).

Mehrotra et al. (2003) utilizaram reator UASB de $12 \mathrm{~L}$ a $30^{\circ} \mathrm{C}$, com TDH de 0,5 d, tratando água residuária contendo $1176 \mathrm{mg} / \mathrm{L}$ de fenol, produziu 32 L/d de biogás, valor superior ao encontrado neste estudo. Os principais pontos que podem ser indicados como responsáveis por esta constatação foram a configuração do reator (UASB), maior volume total (12 L) e diferente TDH $(0,5 \mathrm{~d})$.

\subsection{Avaliação da adesão microbiana no material suporte}

As Figuras 4.14 a 4.18 mostram as fotografias obtidas através da microscopia eletrônica de varredura das partículas de poliestireno amostradas ao final de cada fase de operação do reator.

Vale ressaltar que o ataque ácido com solução sulfocrômica e ácido nítrico concentrado tiveram como objetivo o aumento da rugosidade superficial do poliestireno como meio suporte. 


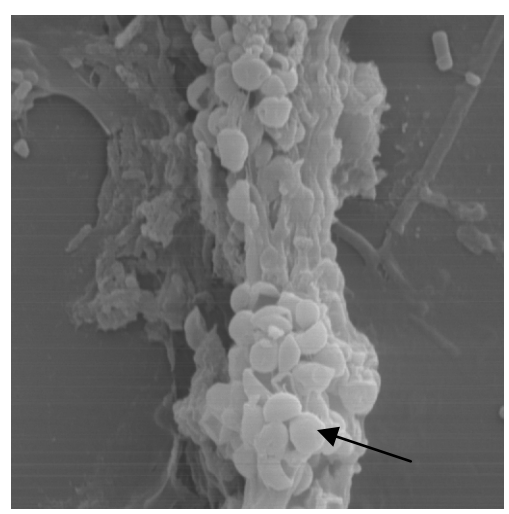

(a)

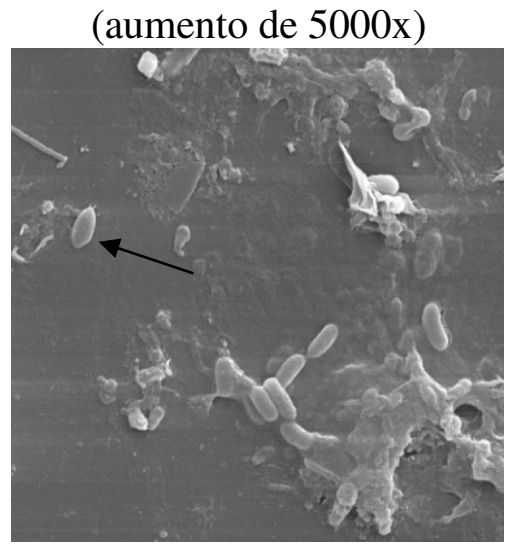

(d)

(aumento de 5000x)

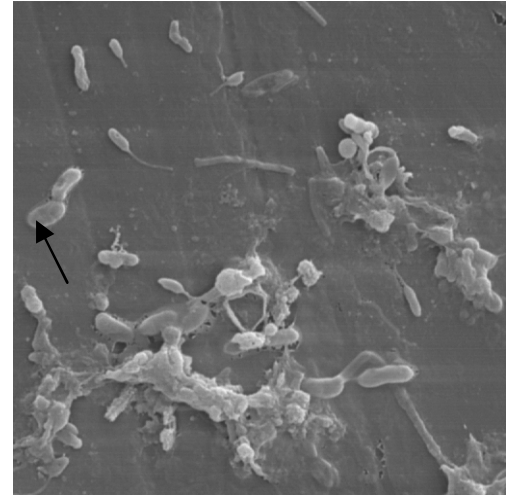

(b)

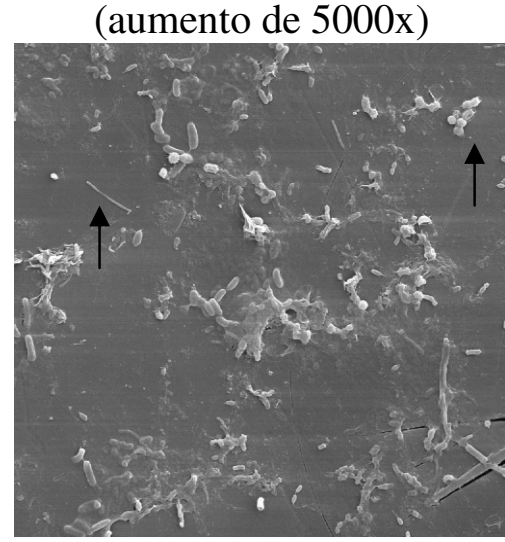

(e)

(aumento de 2000x)

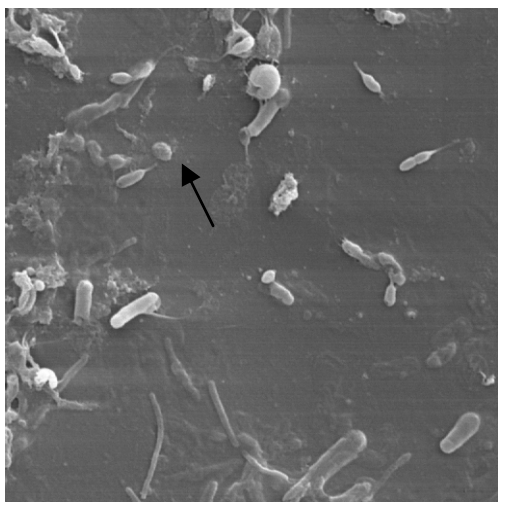

(c)

(aumento de 5000x)

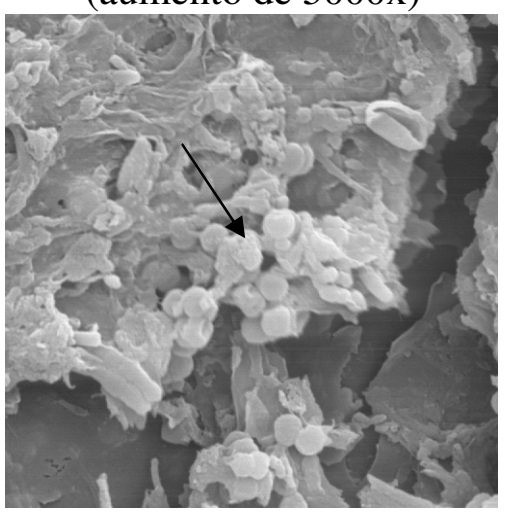

(f)

(aumento de 5000x)

Figura 4.14 - Adesão das células e formação de biofilme nas partículas de poliestireno para a fase II, concentração de $100 \mathrm{mg} / \mathrm{L}$ no $57^{\circ}$ dia de operação (a) Cocos e morfologias semelhantes à Methanosaeta sp., (b) bacilos ovalados, (c) cocos, (d) bacilos ovalados, (e) cocos e filamentos delgados e (f) Matriz gelatinosa, cocos e morfologias semelhantes à Methanosarcina sp. 


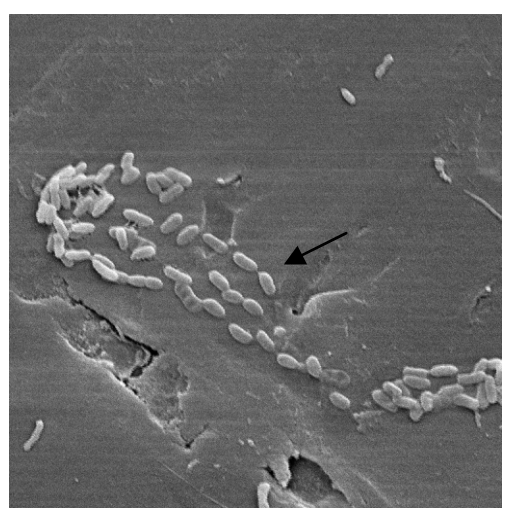

(a)

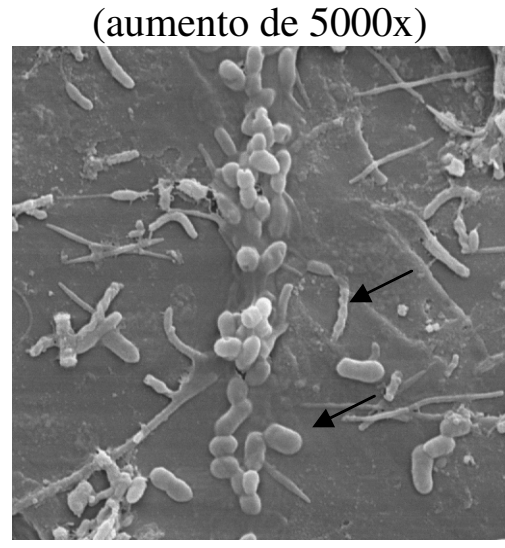

(d)

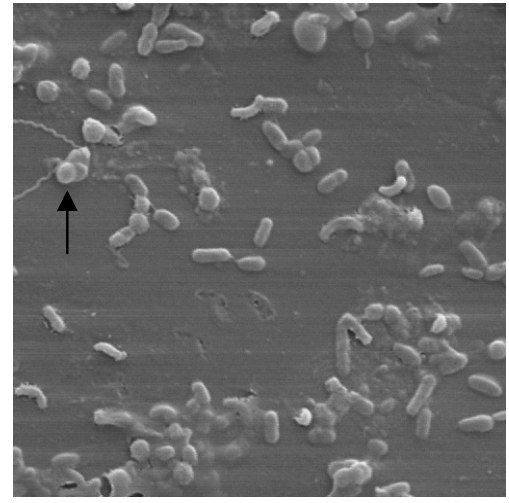

(b) (aumento de 5000x)

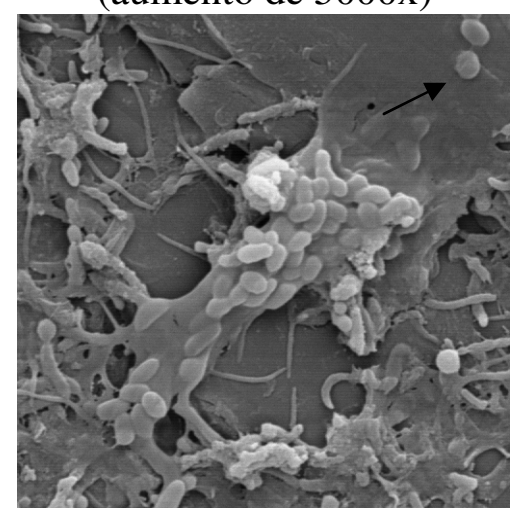

(e)

(aumento de 5000x)

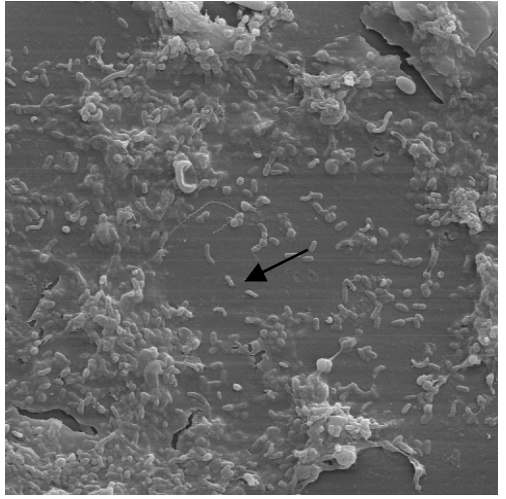

(c)

(aumento de 2000x)

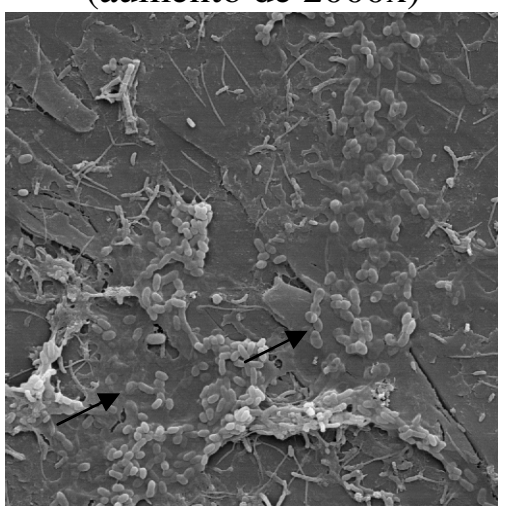

(f)

(aumento de 2000x)

Figura 4.15 - Adesão das células e formação de biofilme nas partículas de poliestireno para a fase IV, concentração de $300 \mathrm{mg} / \mathrm{L}$ no $118^{\circ}$ dia de operação (a) bacilos ovalados, (b) cocos, (c) bacilos, (d) bacilos ovalados, (e) cocos e (f) bacilos, cocos. 


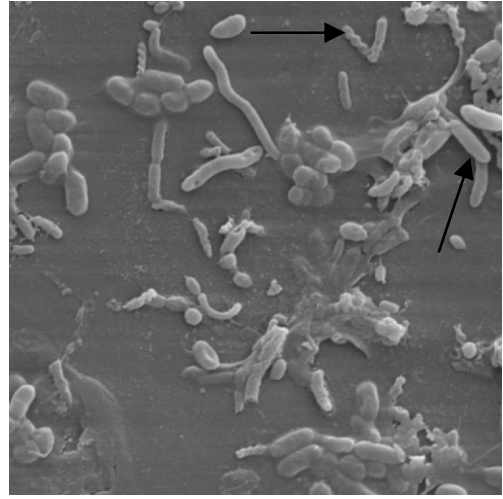

(a)

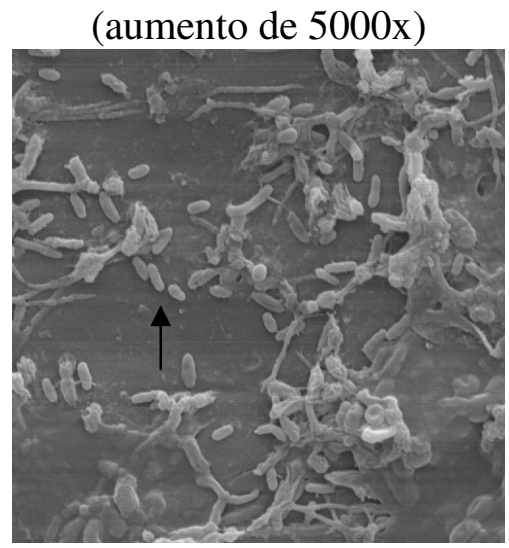

(d)

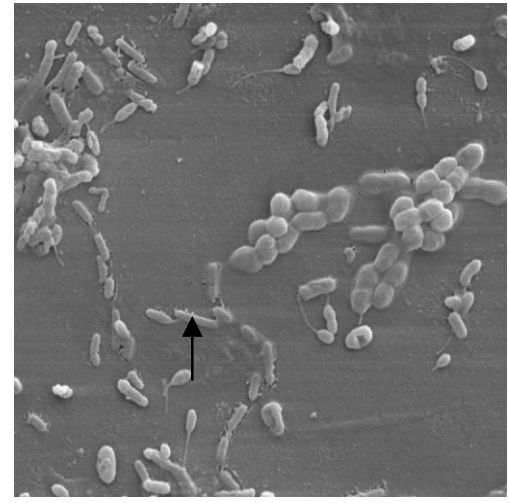

(b)

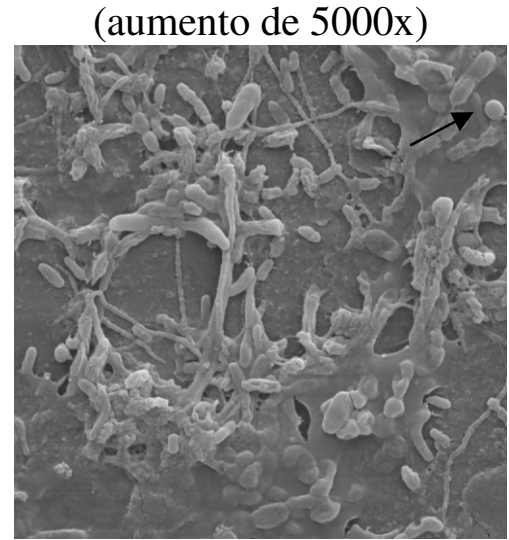

(e)

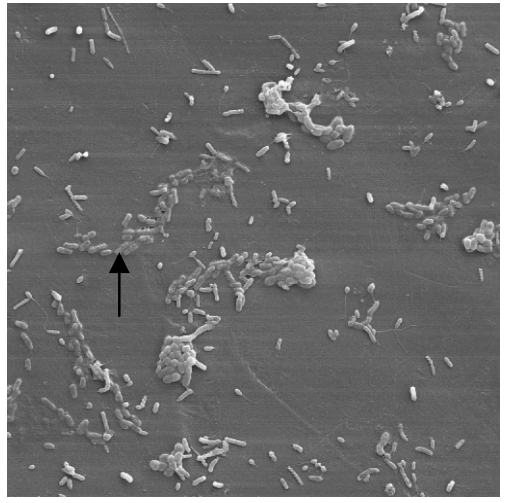

(c)

(aumento de 2000x)

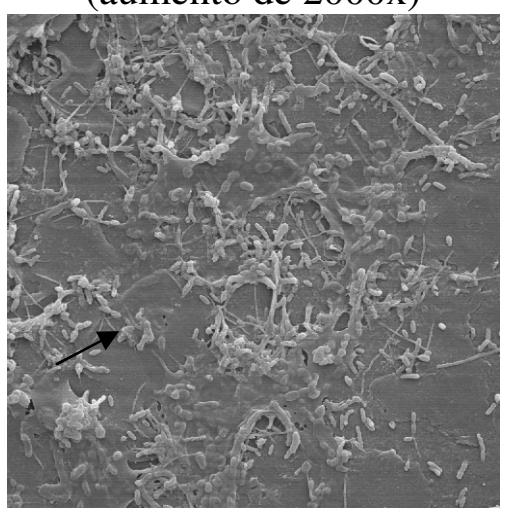

(f)

(aumento de 5000x)

(aumento de 2000x)

Figura 4.16 - Adesão das células e formação de biofilme nas partículas de poliestireno para a fase $\mathrm{V}$, concentração de $400 \mathrm{mg} / \mathrm{L}$ no $128^{\circ}$ dia de operação (a) espiroquetas, espirilos e bacilos ovalados, (b) bacilos retos, (c) bacilos, (d) bacilos ovalados, (e) cocos e (f) bacilos. 


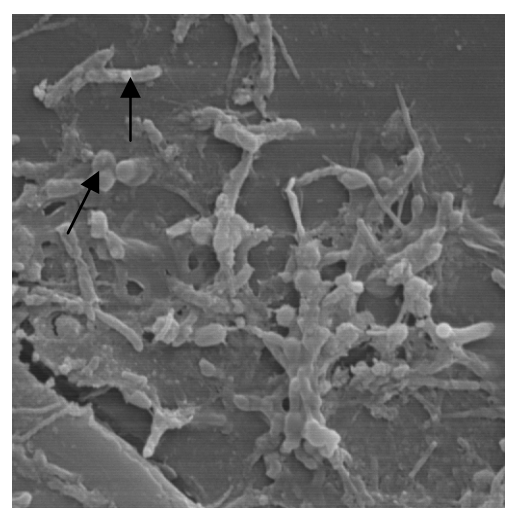

(a)

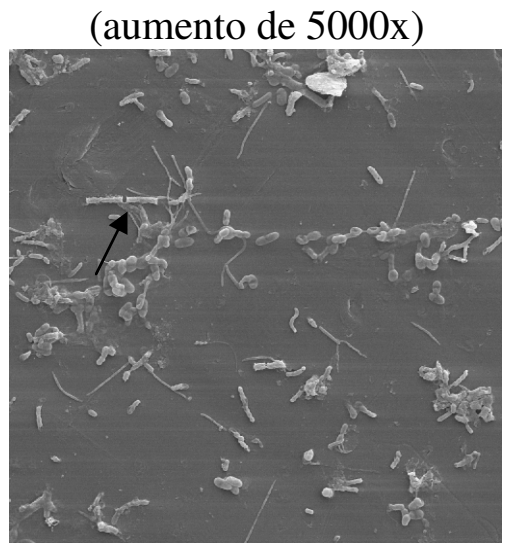

(d)

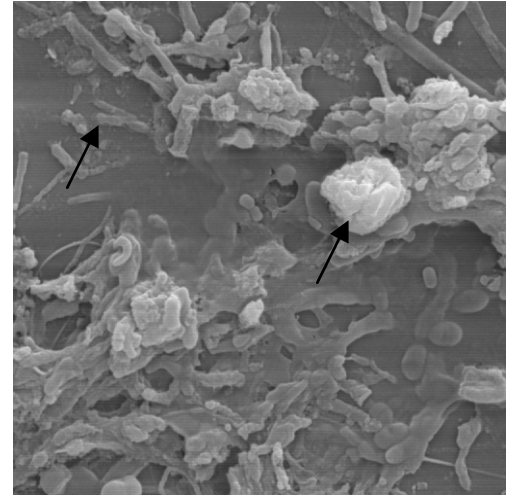

(b)

(aumento de 5000x)

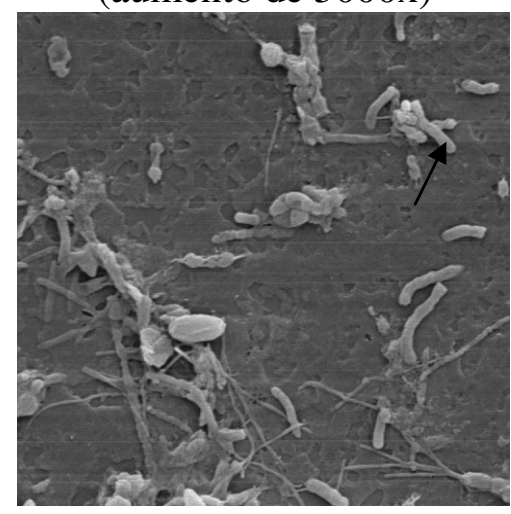

(e)

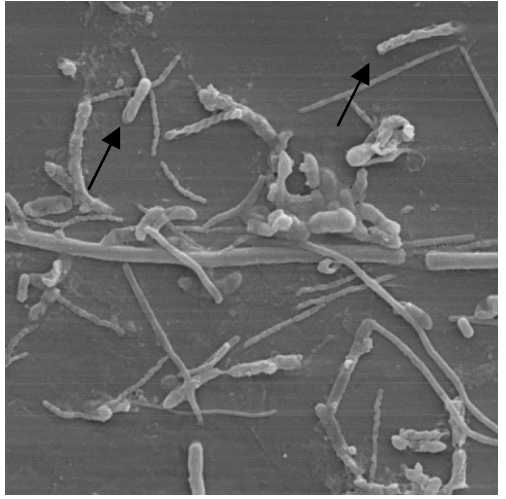

(c)

(aumento de 5000x)

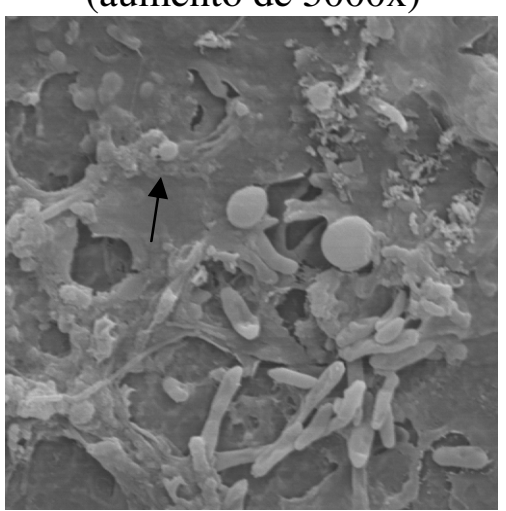

(f)

(aumento de 2000x)

(aumento de 5000x)

Figura 4.17 - Adesão das células e formação de biofilme nas partículas de poliestireno para a fase VI, concentração de $500 \mathrm{mg} / \mathrm{L}$ no $151^{\circ}$ dia de operação (a) morfologias semelhantes à Methanosaeta sp., cocos, (b) bacilos, morfologias semelhantes à Methanosaeta sp, (c) filamentos, bacilos, (d) morfologias semelhantes à Methanosaeta sp., (e) bacilos e (f) cocos. 


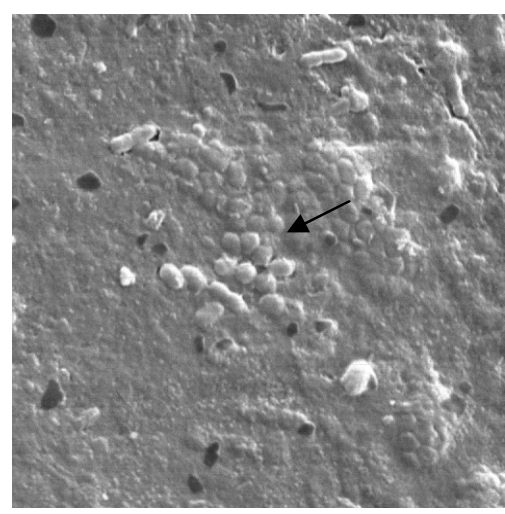

(a)

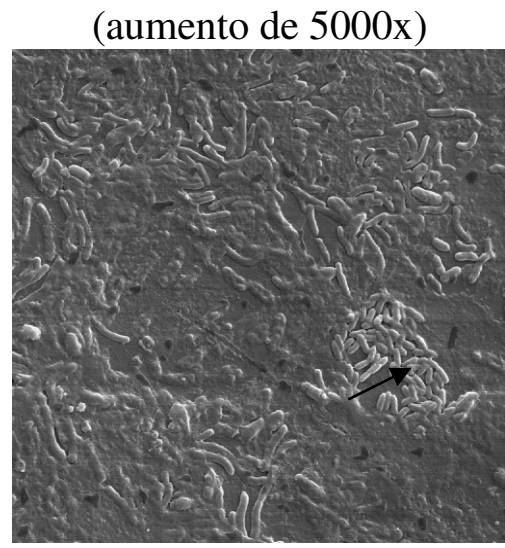

(d)

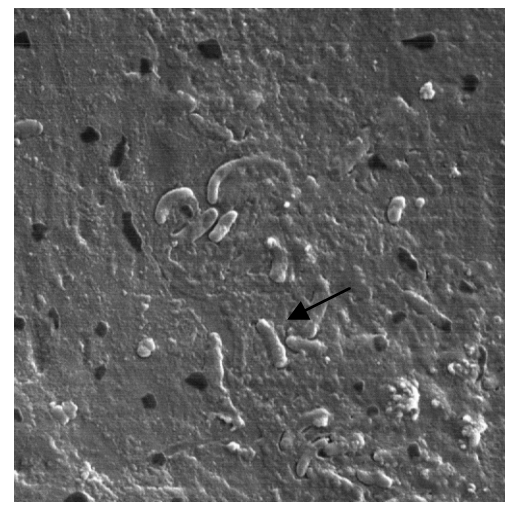

(b)

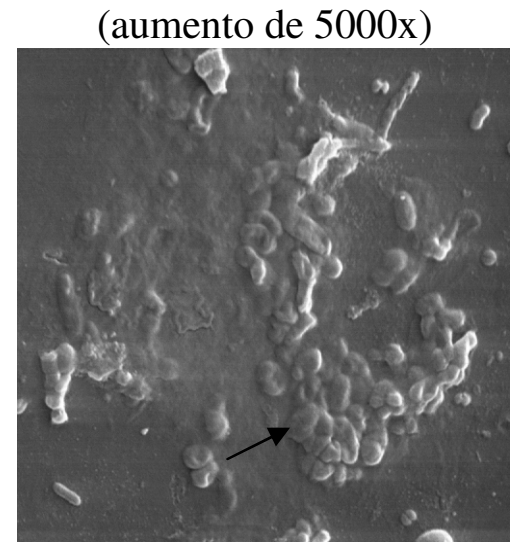

(e)

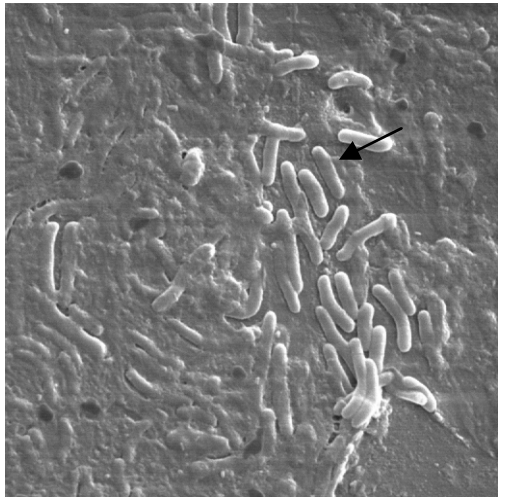

(c)

(aumento de 5000x)

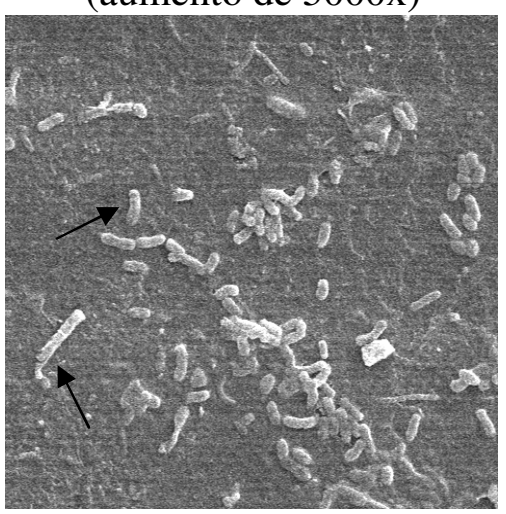

(f)

(aumento de 3000x)

(aumento de 3000x)

Figura 4.18 - Adesão das células e formação de biofilme nas partículas de poliestireno para a fase VIII, concentração de $700 \mathrm{mg} / \mathrm{L}$ no $177^{\circ}$ dia de operação (a) cocos, (b) bacilos, (c) bacilos, (d) bacilos, (e) cocos e (f) bacilos e morfologias semelhantes à Methanosaeta sp. 
As fotos obtidas por meio da microscopia eletrônica de varredura mostram que a metodologia adotada para o ataque ácido nas partículas de poliestireno antes de serem colocadas no reator foi adequada. Foi constatada a melhoria da adesão com o tempo de operação do reator em todas as partes das partículas de poliestireno. Durante a operação do reator anaeróbio de leito fluidificado as morfologias predominantes encontradas foram bacilos, retos, ovalados, espiralados, víbrios e cocos, pôde-se encontrar morfologias semelhantes a Metahanosaeta sp., indicando que os ácidos produzidos são convertidos a metano, onde foi verificado a produção de metano através do sistema de deslocamento de líquido.

Durante os problemas ocorridos na fase IV (300 mg/L de fenol), os microrganismos permaneceram aderidos conforme apresentado nas Figuras 4.15 e 4.16, o qual representa o período posterior aos problemas operacionais.

Na Figura 4.19, podemos observar as perdas de SSV durante a operação do RALF onde ocorreram problemas operacionais.

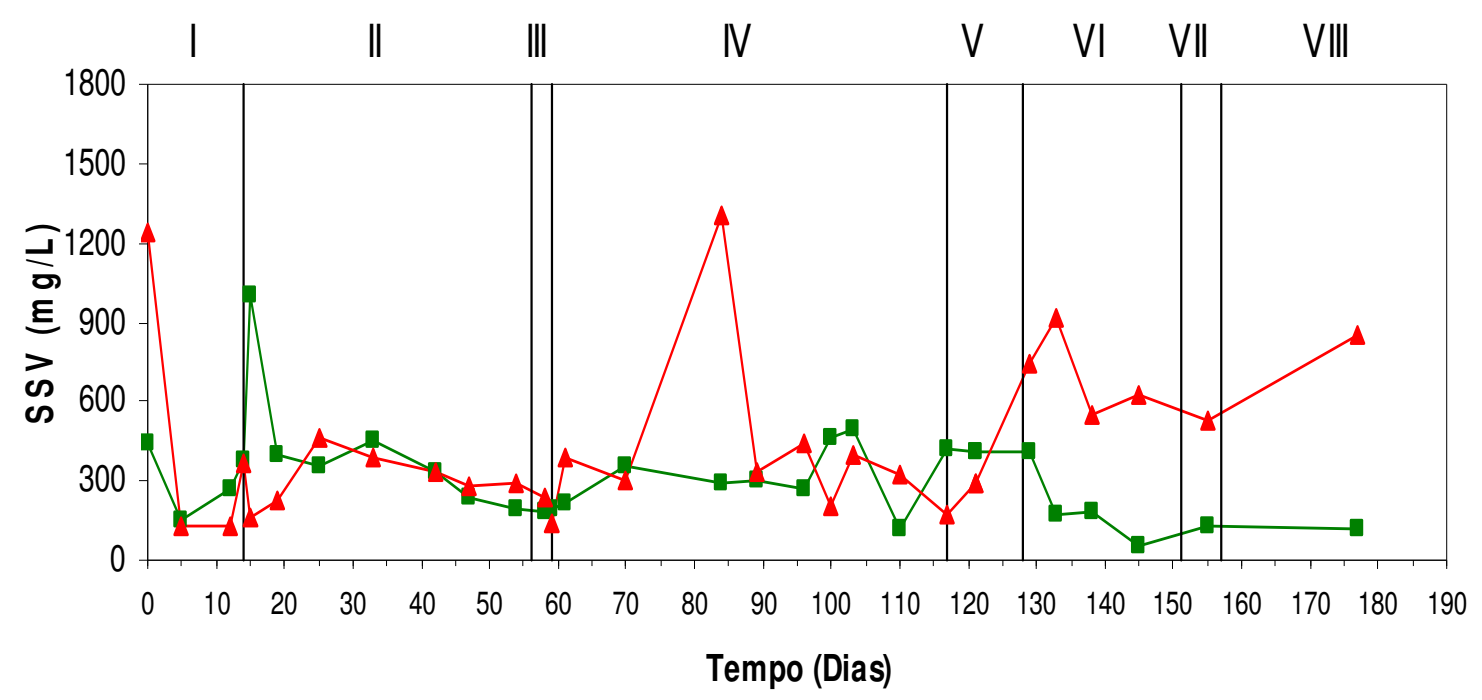

Figura 4.19 - Variação temporal dos Sólidos Suspensos Voláteis (SSV) afluente (--) e efluente $(\star-)$ no reator anaeróbio de leito fluidificado. 
No início da operação do RALF observa-se que o valor de SSV efluente foi superior ao efluente, essa constatação pode ser atribuída ao período de partida do sistema, quando o reator estava sendo inoculado e esse inóculo possuía elevada concentração de SSV.

Os picos apresentados para os SSV efluente na Figura 4.19, representam os períodos em que o sistema sofreu quedas de energia ocasionando no empacotamento do leito do RALF, perdendo biomassa.

Desta forma, a queda de desempenho do reator pode ser atribuída à agressão sofrida pelo sistema devido aos jatos de nitrogênio aplicados no reator anaeróbio de leito fluidificado para desempacotar o leito quando ocorriam quedas de energia.

A altura de fluidificação inicial foi 88,5 cm e nos dias seguintes atingiu $142 \mathrm{~cm}, 117$ $\mathrm{cm}$ e $162 \mathrm{~cm}$, atingindo uma altura crítica no reator, onde as partículas poderiam ser carreadas para a bomba de recirculação podendo acarretar em possíveis entupimentos no sistema de recirculação. A expansão do leito de $88,5 \mathrm{~cm}$ para $162 \mathrm{~cm}$ pode ser atribuída ao aumento da adesão microbiana no material suporte. Após o dia $150^{\circ}$ de operação com $500 \mathrm{mg} / \mathrm{L}$ de fenol aumentou-se para $600 \mathrm{mg} / \mathrm{L}$ e 24 horas depois a altura de fluidificação voltou para $88 \mathrm{~cm}$, devido ao empacotamento do leito ocasionado pela queda de energia, quando foi possível observar que houve desprendimento da biomassa nas partículas da parte superior do reator, representado na Figura 4.19 durante a operação do RALF na fase VII, apresentando a perda de cerca de $500 \mathrm{mg} / \mathrm{L}$ de SSV, o que não comprometeu no desempenho do reator.

Durante a operação do RALF com alimentação de $600 \mathrm{mg} / \mathrm{L}$ de fenol, a altura de fluidificação voltou ao nível inicial da operação, aproximadamente $89 \mathrm{~cm}$, não sendo necessária alteração na vazão de recirculação como efetuado por Diez Blanco et al. (1995). Essa constatação pode ser relacionada a retomada da estabilidade do sistema relacionada aos SSV. 
Diez Blanco et al. (1995) observaram que o desenvolvimento do biofilme apresentou efeito significativo no comportamento hidrodinâmico no reator anaeróbio de leito fluidificado com partículas de argila fibrosa como meio suporte e água residuária sintética com ácido acético como fonte de carbono. A razão de recirculação precisou ser reduzida para manter determinada expansão quando os sólidos voláteis aderidos aumentaram. A velocidade superficial necessária para manter $20 \%$ de expansão do leito diminui de $11,5 \mathrm{~m} / \mathrm{h}$ para partículas limpas para $9,0 \mathrm{~m} / \mathrm{h}$ para concentração de $20 \mathrm{~g} / \mathrm{L}$ de sólidos voláteis aderidos. $\mathrm{O}$ crescimento do biofilme variou ao longo do reator, aumentando a variação natural no tamanho das partículas do leito.

A Figura 4.14(a) mostra a formação de matriz polimérica, indicando melhoria da estabilidade microbiana com o aumento do tempo de operação do reator anaeróbio de leito fluidificado.

Com as observações microscópicas permitiu concluir que a partícula polimérica (poliestireno) pode ser utilizada como meio suporte para o desenvolvimento e formação do biofilme em reatores anaeróbios de leito fluidificado. 


\section{CAPÍTULO 5}

\subsection{Conclusões}

Os resultados obtidos mostraram que o reator de leito fluidificado apresentou desempenho satisfatório com relação à remoção de fenol de $90 \%$ e redução de DQO de $88 \%$ da água residuária sintética analisada.

A adaptação do lodo de suinocultura ao fenol no próprio reator permitiu uma partida rápida do reator, além de manter as condições de anaerobiose e do procedimento adotado na etapa de inoculação do reator. Diferentemente do trabalho de Sancinetti (2004), o inóculo utilizado foi retirado diretamente dos ensaios de adaptação em shakers e usado para inocular os reatores.

Durante a adaptação do inóculo foram encontradas morfologias (bacilos, víbrios, morfologias semelhantes a Methanosaeta sp. e Methanosarcina sp.) coerentes as encontradas por outros pesquisadores.

As oscilações na vazão de alimentação e as quedas de energia, observadas nos dias 23, 37, 61, 63, 68, 69, 77, 92, 96 e 100 no reator, comprometeram no desempenho do reator, porém nas análises do dia seguinte mostrou que o reator consegue absorver o impacto gerado pela sobrecarga de alimentação, principalmente quando operado com carga a partir de 300 $\mathrm{mg} / \mathrm{L}$ de fenol.

As eficiências de remoção de fenol para concentrações de 50 mg/L, 100 mg/L, 200 $\mathrm{mg} / \mathrm{L}, 300 \mathrm{mg} / \mathrm{L}, 400 \mathrm{mg} / \mathrm{L}, 500 \mathrm{mg} / \mathrm{L}, 600 \mathrm{mg} / \mathrm{L}$ e $700 \mathrm{mg} / \mathrm{L}$ de fenol aplicadas no reator foram de $98,9 \%, 95,5 \%, 99,3 \%, 80,6 \%, 82,6 \%, 99,4 \%, 89,3 \%$ e $74,2 \%$, respectivamente.

A eficiência média para todo o sistema sob taxa de carregamento orgânico variando entre 0,09 a $1,29 \mathrm{~kg}$ fenol $/ \mathrm{m}^{3} \mathrm{~d}$ foi aproximadamente $90 \%$. 
As eficiências médias de redução de DQO para as concentrações de $50 \mathrm{mg} / \mathrm{L}, 100$ mg/L, $200 \mathrm{mg} / \mathrm{L}, 300 \mathrm{mg} / \mathrm{L}, 400 \mathrm{mg} / \mathrm{L}, 500 \mathrm{mg} / \mathrm{L}, 600 \mathrm{mg} / \mathrm{L}$ e $700 \mathrm{mg} / \mathrm{L}$ de fenol aplicadas no reator foram de $91,9 \%, 90,2 \%, 96,0 \%, 81,2 \%$ e $86,12 \%, 99,9 \%, 86,9 \%$ e $73,5 \%$, respectivamente.

$\mathrm{O}$ pH se manteve estável no reator estudado, ficando dentro da faixa desejada, de 6,59 e 8,21, para sistemas anaeróbios.

Os valores médios de alcalinidade a bicarbonato estiveram maiores no efluente do reator, excluindo o provável acúmulo de ácidos voláteis. No reator a média foi de $180 \mathrm{mg} / \mathrm{L}$ no afluente e $294 \mathrm{mg} / \mathrm{L}$ no efluente.

A partícula de poliestireno mostrou ser adequada para adesão microbiana, sendo observado presença de morfologias semelhantes a Methanosaeta sp., bacilos retos, ovalados, espiralados, víbrios e cocos. 


\subsection{Sugestões}

Objetivando contribuir para futuros estudos de degradação anaeróbia de fenol em reator anaeróbio de leito fluidificado, sugere-se:

a) Aplicar maiores concentrações de fenol ao reator, uma vez que o desempenho foi satisfatório até a concentração empregada de $700 \mathrm{mg} / \mathrm{L}$;

b) Avaliar o desempenho do reator diminuindo o tempo de detenção hidráulica;

c) Fazer acompanhamento detalhado do desenvolvimento do biofilme, verificando sua espessura;

d) Estudar a rota de degradação anaeróbia do fenol e verificar os compostos intermediários formados;

e) Estudar a degradação de fenol sob condições desnitrificantes, utilizando consórcios de microrganismos anaeróbios com potencial de degradar eficientemente o fenol;

f) Estudar a degradação de fenol em reator anaeróbio de leito fluidificado sob condições termofílicas;

g) Estudar a degradação de fenol com o uso de esgoto sanitário como co-substrato. 


\section{REFERÊNCIAS BIBLIOGRÁFICAS}

ALNAIZY, R.; AKGERMAN, A. Advanced oxidation of phenolic compounds. Advances in Environmental Research, 4, p. 233-244, 2000.

ANNADURAI, G.; JUANG, R.S.; LEE, D.J. Microbiological degradation of phenol using mixed liquors of Pseudomonas putida and activated sludge. Waste Management, 22, p.703-710, 2002.

APHA (American Public Health). Standard Methods for the Examination for Water and Wastewater. 17th ed. New York. 1995.

ARAÚJO, J.C. Caracterização e evolução do biofilme em reator anaeróbio de leito fluidificado alimentado com esgoto sanitário sintético. São Carlos. Dissertação (Mestrado) - SHS-EESC-USP, 1995.

ARAÑA, J.; RENDÓN, E.T.; RODRÍGUES, J.M.D.; MELIÁN, J.A.H.; DÍAZ, O.G.; PEÑA, J.P. Highly concentrated phenolic wastewater treatment by the Photo-Fenton reaction, mechanism study by FTIR-ATR. Chemosphere, 44, p.1017-1023, 2001.

BAKKER, G. Anaerobic Degradation of aromatic compounds in the presence of nitrate. FEMS Microbiology Letters, V. 1,P. 103-108, 1977.

BÉCHARD, G.; BISAILLON, J.G.; BEAUDET, R.; SYLVESTRE, M. Degradation of phenol by a bacterial consortium under methanogenic conditions. Canadian Journal of Microbiology. 36 (8): p 573-578, 1990.

BEHLING, E.; DIAZ, A.; COLINA, G.; HERRERA, M.; GUTIERREZ, E.; CHACIN, E. Domestic wastewater treatment using a UASB reactor. Bioresour Technol. 6:239-45, 1997.

BERTOLLO, F.B. Avaliação do reator de leito fluidizado com tubo draft na biodegradação de fenol. Tese (Mestrado). Universidade Federal de São Carlos, 2001.

BOLANÕS, R.M.L. Tratamento de fenol em reator anaeróbio horizontal de leito fixo (RAHLF) sob condições mesofílicas. São Carlos. Tese (Doutorado) SHS-EESC-USP, 2001. 
BUFFIÈRE, P.; MOLETTA, R.; FONADE, C. Continuous operations of a fluidized bed bioreactor for anaerobic digestion: residence time effect on degradation kinetics. Biotechnol. Lett., 17(8): 833-838, 1995.

BUFFIÈRE, P.; STEYER, J.P.; FONADE, C.; MOLETTA, R. Modeling and experiments on the influence of biofilm size and mass transfer in a fluidized bed reactor for anaerobic digestion. Water Research, v.32, n 3, p. 657-668, 1998.

CAMPOS, J.R.; PEREIRA, J.A.R. Reator Anaeróbio de Leito Expandido/Fluidificado. In: Campos, J.R. (Coord.) Tratamento de Esgotos Sanitários por Processo Anaeróbio e Disposição Controlada no Solo, PROSAB/ABES, 199-219, 1999.

CETESB. Determinação de fenóis em águas - Método colorimétrico da 4-amino-antipirina. L5.125 set 1990.

CHANG, Y.J.; NISHIO, N.; NAGAI, S. Characteristics of granular methanogenic sludge grown on phenol synthetic medium and methanogenic fermentation of phenolic wastewater in a UASB reactor. Journal of Fermentation and Bioengeneering. v 79, n. 4, p. 348-353, 1995.

CHERNICHARO, C.A.L. Reatores anaeróbios — DESA, UFMG, Belo Horizonte, 1997.

CHEN, S.J.; LI, C.T.; SHIEH, W.K. Anaerobic fluidized bed treatment of a tannery wastewater. Chem. Eng. Res. Des., 66: 518-523, 1988.

CHENG, S.S.; HSU, T.K.; CHANG, F.B.; HUANG, S.Y. Treatment of phenolic wastewater with anaerobic GAC fluidized-bed process. Sixth Internation Symposium on Anaerobic Digestion, São Paulo, Brazil, p. 219-229, 1991.

CONAMA Resolução CONAMA n ${ }^{\circ}$ 357, de 17 de março de 2005.

COSTA, S.R.A. Remoção de fenol em reator anaeróbio de leito fluidificação de carvão ativado. 199 f. Tese (Doutorado em Hidráulica e Saneamento) - Escola de Engenharia de São Carlos, Universidade de São Paulo, São Carlos, 1994.

COSTA, J.M.P. Estudo de tratabilidade de água residuária sintética simulando despejo líquido de coquerias. São Paulo. Tese (Doutorado) - DHS-EP-USP, 1999. 
COSTERTON, J.W.; LEWANDOWSKI, Z.; CALDWELL, D.E.; KORBER, D.R.; LAPPINSCOTT, H.M. Microbial biofilms. Annual Reviews im Microbiology, v. 49, p. 711-745, 1995.

COSTERTON, J.W.; LEWANDOWSKI, Z. The biofilm lifestyle. Advances in Dental Research, v. 11, n.1, p. 192-195, 1997.

COLBERG, P.J.S.; YOUNG, L.Y. Microbial transformation and degradation of toxic organic chemicals: cap 8: Anaerobic degradation of nonhalogenated homocyclic aromatic compounds coupled with nitrate, iron, or sulfate redution. Edited by Lily Y. YOUNG, Carl E. Cerniglia, Wiley-Liss Inc. New York. 654p, 1995.

DEL NERY, V. Utilização de lodo anaeróbio imobilizado em gel no estudo de partida de reatores de fluxo ascendente com manta de lodo. Dissertação (Mestrado em Hidráulica e Saneamento) - Escola de Engenharia de São Carlos, Universidade de São Paulo, 1987.

DENAC, M.; DUNN, I.J. Packed- and fluidized- bed biofilm reactor performance for anaerobic wastewater treatment. Biotechnol. Bioeng., 32: 159-173, 1988.

DIEZ BLANCO, V.; GARCÍA ENCINA, P.A., FDZ-POLANCO, F. Effects of biofilm growth, gas and liquid velocities on the expansion of an anaerobic fluidized bed reactor (AFBR). Water Research, v. 29, n. 7, p. 1649-1654, 1995.

DILALLO, R.; ALBERTSON, O.E. Volatile Acids by Direct Titration. Journal of Water Pollution Control Federation. (33) N.4, PP.357-365, 1961.

FANG, H.H.P.; CHEN, T.; LI, Y.-Y.; CHUI, H.-K. Degradation of phenol in wastewater in an upflow anaerobic sludge blanket reactor. Water Research, vol. 30, n. 6, pp. 1353-1360, 1996.

FANG, H.H.P.; ZHOU, G-M. Interactions of methanogens and denitrifies in degradation of phenol. Journal of Environmental Engineering. v 125, n 1, p. 57-63, 1999.

FANG, H.H.P.; ZHOU, G-M. Degradation of phenol and $p$-cresol in reactors. Water Science and Technology. v 42, n 5-6, p. 237-244, 2000.

FANG, H.H.P.; LIU, Y.; KE, S.Z.; ZHANG, T. Anaerobic degradation of phenol in wastewater at ambient temperature. Water Science and Technology, 49 (1): 95-102, 2004. 
FANG, H.H.P.; LIANG, D.W.; ZHANG, T.; LIU, Y. Anaerobic treatment of phenol in wastewater under thermophilic condition. Water Research. 40: 427 - 434, 2006.

FUCHS, G.; EL SAID MOHAMED, M.; ALTENSCHMIDT, U.; KOCH, J.; LACK, A.; BRACKMANN, R.; LOCHMEYER, C.; OSWALD, B. Biochemistry of anaerobic biodegradation of aromatic compounds. In: RATLEDGE. C. (Ed.) Biochemistry of microgial degradation, p. 513-533, 1994.

GALLERT, C.; WINTER, J. Uptake of phenol by phenol-metabolizing bacteria of a stable, strictly anaerobic consortium. Applied Microbiology and Biotechnology, 39 : 627 - 631, 1993.

GALLERT, C.; WINTER, J. Anaerobic degradation of 4-hydroxybenzoate: reductive dehydroxylation of 4-hydroxybenzoil-CoA and ATP formation during 4-hydroxybenzoate decarboxylation by the phenol-metabolizing bacteria of a stable, strictly anaerobic consortium. Applied Microbiology and Biotechnology, 42 : 408 - 414, 1994.

GERNJAK, W.; KRUTZLER, T.; GLASER, A.; MALATO, S.; CACERES, J.; BAUER, R.; FERNÁNDEZ-ALBA, A.R. Photo-Fenton treatment of water containing natural phenolic pollutants. Chemosphere, 50, p.71-78, 2003.

GONZÁlEZ, G.; RAMÍREZ, F.; MONROY, O. Development of biofilms in anaerobic reactors. Biotechnology Letters, v. 14, n. 2, p. 149-154, 1992.

HANAKI, K.; HIRUNMASUWAN, S.; MATSUO, T. Protection of methanogenic bacteria from low $\mathrm{pH}$ and toxic materials by immobilization using polyvinyl alcohol. Water Research. 28, p.877-885, 1994.

HANAKI, K.; SAITO, T.; MATSUO, T. Anaerobic treatment utilizing the function of activated carbon. Wat. Sci. Tech., 35(8): 193-201, 1997.

HECHT, V.; LANGER, O.E.; DECKWER, W.D. Degradation of phenol and benzoic acid in a three-phase fluidized-bed reactor. Biotechnol. Bioeng., 70(4): 391-399, 2000.

HICKEY, R.F.; OWENS, R.W. Methane generation from thigh-strength industrial wastes with the anaerobic biological fluidized bed. Biotechnol. Bioeng., 23: 399-413, 1981. 
HIDALGO, M.D.; GARCÍA-ENCINA, P.A. Biofilm development and bed segregation in a methanogenic fluidized bed reactor. Water Research, v. 36, p. 3083-3091, 2002.

HIRATA, A.; NOGUCHI, M.; TAKEUCHI, N.; TSUNEDA, S. Kinetics of biological tretament of phenolic wastewater in three-phase fluidized bed containing biofilm and suspended sludge. Wat. Sci. Tech., 38(8-9), 205-212, 1998.

HOLST, T.C.; TRUC, A. E.; PUJOL, R. Anaerobic fluidized beds: ten years of industrial experience. Wat. Sci. Tech., 36(6-7): 415-422, 1997.

HWANG, P.C.; CHENG, S.S. Treatment of p-cresol with a recirculating UASB reactor using the concept of kinetic control. Water Sci.Technol. 24 (5), 133-140, 1991a.

HWANG, P.C.; CHENG, S.S. The influence of glucose supplement on the degradation of catechol. Water Sci. Technol. 23, 1201-1209, 1991 b.

KENNES, C.; MENDEZ, R. E.; LEMA, J.M. Methanogenic degradation of p-cresol in batch and in continuous UASB reactors. Wat. Res., 31(7): 1549-1554, 1997.

KINDZIERSKI, W.B.; FEDORAK, P.M.; GRAY, M.R.; HRUDEY, S.E. Activated carbon and synthetic resins as support material for methanogenic phenol-degrading consortiacomparison of surface characteristics and initial colonization. Water Environmental Research. 64, p.766-775, 1992.

KOBAYASHI, T.; HASHINAGA, T.; MIKAMI, E.; SUZUKI, T. Methanogenic degradation of phenol and benzoato in acclimated sludges. Water Science Technology, vol. 21, pp. $55-65,1989$.

KURODA, M.; YUZAWA, M.; SAKAKIBARA, Y.; OJAMURA, M. Methanogenic bactéria adhered to solid supports. Water Research. 22, p.653-656, 1988.

KUŞÇU, Ö.S.; SPONZA, D.T. Treatment efficiencies of a sequential anaerobic baffled reactor $(\mathrm{ABR}) /$ completely stirred tank reactor (CSTR) system at increasing p-nitrophenol and COD loading rates. Process Biochemistry. 41: 1484-1492, $2006 \mathrm{a}$.

KUŞÇU, Ö.S.; SPONZA, D.T. Performance of p-nitrophenol (p-NP) fed sequential anaerobic migrating blanket reactor (AMBR)/aerobic completely stirred tank reactor system under 
increasing organic loading conditions. Enzyme and Microbial Technology, 2006b, doi:10.1016/j.enzmictec.2006.08.001

KUMARAN, P.; PARUCHI, Y.L. Kinetics of phenol biotransformation. Water Research, 31, 1, p.11-22, 1997.

LEITE, J.V. Avaliação da toxicidade do fenol em sistemas de lodos ativados: utilização do método fed-batch reactor (FBR) modificado. São Paulo. Tese (Doutorado) - DHS-EPUSP, 1997.

LETTINGA, G.L.W.; HUSHOFF, P.I.; KOSTER, V.M.; WEIGANT, W.J.; DE ZEEUW, A. High rate anaerobic wastewater treatment using the UASB reactor under a wide range of temperature conditions. Biotech and Genetic Rev; p.253-84, 1984.

LETTINGA, G.; FIELD, J.; VAN LIER, J.; ZEEMAN, G.; HULSHOFF POL, L.W. Advanced anaerobic wastewater treatment in the near future. Wat. Sci. Tech., 35(10): 5$12,1997$.

LIN, Y.H.; LEE, K.K. Verification of anaerobic biofilm model for phenol degradation with sulfate reduction. Journal of Environmental Engineering-ASCE, v. 127, n.2, p. 119-125, 2001.

LONDRY, K.L.; FEDORAK, P.M. Benzoic acid intermediates in the anaerobic biodegradation of phenol. Canadian Journal Microbiology, 38 : 1-11, 1992.

MARTINELLI, F.R. Formação e desenvolvimento do biofilme em reator de leito fluidizado na degradação anaeróbia de fenol. Trabalho de Graduação. Departamento de Engenharia Química - UFSCar, 2003.

MATSUDA, F. Y. Integração de processos fotoquímicos e biológico na degradação de fenol em efluentes aquosos. São Paulo. Dissertação (Mestrado) - Escola Politécnica da Universidade de São Paulo - Departamento de Engenharia Química-USP, 2005.

MEHROTRA, I.; KUMAR, P.; GALI, V. Treatment of phenolic wastewater using upflow anaerobic sludge blanket reactor. Proceedings of National Conference on Biological Treatment of Wastewater and Waste Air, August 28 and 29, Regional Research Laboratory (CSIR), Trivandrum, India, 2003. 
MENDONÇA, N.M. Caracterização do material suporte e estudo da partida de um reator anaeróbio de leito expandido utilizado no tratamento de esgoto sanitário. Tese Mestrado. Escola Engenharia de São Carlos, Universidade de São Paulo, 1999.

METCALF \& EDDY, INC. Wastewater engineering: treatment, disposal, and reuse. McGraw-Hill, Inc., 1334p, 1979.

METCALF \& EDDY, INC. Wastewater engineering: treatment, disposal, and reuse. McGraw-Hill, 1991.

MORAES, E. M.; ADORNO; M. A. T.; ZAIAT, M., FORESTI, E. Determinação de ácidos voláteis por cromatografia gasosa em efluentes de reatores anaeróbios tratando resíduos líquidos e sólidos. In: VI Oficina e Seminário Latino-Americano de Digestão Anaeróbia, 2000, Recife - PE. Anais da VI Oficina e Seminário Latino-Americano de Digestão Anaeróbia. Editora Universitária - UFPE. v.2. p.235-238, 2000.

NICOLELLA, C.; VAN LOOSDRECHT, M.C.M.; HEIJNEN, J.J. Wastewater treatment with particulate biofilm reactor - Review Article. Journal of Biotechnology, n. 80, p. 1-33, 2000.

OLIVEIRA, R. A.; FORESTI, E. Balanço de massa de reatores anaeróbios de fluxo ascendente com manta de lodo (UASB) tratando águas residuárias de suinocultura. Engenharia Agrícola, Jaboticabal, v.24, n.3, p.807-820, 2004.

PELCZAR, M.; REID, R.; CHAN, E.C.S. Microbiologia. São Paulo: Editora McGraw-Hill Ltda, Volume 1, 1980.

PULLAMMANAPPALLIL, P.C.; CHYNOWETH, D.P.; LYBERATOS, G.; SVORONOS, S.A. Stable performance of anaerobic digestion in the presence of a high concentration of propionic acid. Bioresource Technology. V 78, p. 165-169, 2001.

RAZO-FLORES, E.; INIESTRA-GONZALEZ, M.; FIELD, J.A.; OLGUIN-LORA, P.; PUIG-GRAJALES, L. Biodegradation of mixtures of phenolic compounds in an upwardflow anaerobic sludge blanket reactor. J. Environ. Eng. 129 (11), 999-1006, 2003. 
RIBEIRO, R. Influência do tipo de substrato na dinâmica de formação do biofilme em matrizes de espuma de poliuretano. São Carlos. Dissertação (Mestrado) - Escola de Engenharia de São Carlos - Universidade de São Paulo, 2001.

RIPLEY, L.E.; BOYLE, W.C.; CONVERSE, J.C. Improved alkalimetric monitoring for anaerobic digestion of high-strength wastes. Journal of Water Pollution Control Federation (58), n.5, p.406-411, 1986.

SADER, L.T. Avaliação de Partículas Poliméricas como Material Suporte em Reator Anaeróbio de Leito Fluidizado no Tratamento de Fenol. São Carlos. Dissertação (Mestrado). DEQ-UFSCar, 2005.

SANCINETTI, G.P. Degradação de fenol em reator anaeróbio de leito fluidizado. Tese (Doutorado) - DEQ-UFSCar, 2004.

SANZ, J.; LOMBRAÑA, J.I.; LUIS, A.M.; ORTUETA, M.; VARONA, F. Analysis of the efficiency of three advanced oxidation processes on the generation of hydroxyl radicals in the treatment of phenol. In: $15^{\text {th }}$ International Congress of Chemical and Process Engineering, Praha, Czech Republic, 2002.

SILVA, E.L. Tratamento aeróbio de fenol em reator aeróbio de leito fluidificado trifásico. São Carlos. Tese (Doutorado) SHS-EESC-USP, 1995.

SILVA, G.M.; FRASSON, R.; GONÇALVES, R.F. Filtros biológicos percoladores para póstratamento de efluentes anaeróbios em pequenas comunidades. V Seminário Estadual sobre Saneamento e Meio Ambiente - SESMA, Vitória, 2003.

SPEECE, R.E. Anaerobic Biotechnology for industrial Wasterwaters. $1^{\text {a }}$ Edition, Archae Press, Tennessee, USA. 394p, 1996.

SREEKRISHNAN, T.R.; RAMACHADRAN, K.B.; GHOSH, P. Effect of operating variables on biofilm formation and performance of na anaerobic fluidized-bed bioreactor. Biotechnology and Bioengineering, v. 37, p. 557-556, 1991.

TAVARES, C.R.G. Tratamento aeróbio de efluentes em bioreatores de leito fluidizado trifásico. Tese (Doutorado), COPPE/UFRJ, 1992. 
TAY, J.-H.; HE, Y.-X.; YAN, Y.-G. Improved anaerobic degradation of phenol with supplemental glucose. J. Environm. Eng., 1: 38-45. 2001.

THE MERCK INDEX. An encyclopédia of chemical, drugs and biologicals. Published by Merck Research Laboratrories. Twenty edition, 1996.

TÉRAN, F.J.C. Tratamento de esgoto sanitário sintético empregando reator anaeróbio de leito fluidificado: Desempenho do reator e estudo do biofilme, São Carlos. Tese (Doutorado) SHS-EESC-USP, 1995.

TSCHECH, A.; FUCHS, G. Anaerobic degradation of phenol by purê cultures of newly isolated denitrifying pseudomonas. Archieves Microbiology, v.148, p. 213-217, 1987.

TSCHECH, A.; FUCHS, G. Anaerobic degradation of phenol via carboxylation to 4hydroxybenzoate: In vitro study of isotope exchange between $14 \mathrm{CO} 2$ and 4hydroxybenzoate. Archieves Microbiology, v. 152, p. 549-599, 1989.

VAN SCHIE, P.M.; YONG, L.Y. Isolation and characterization of phenoldegrading denitrifying bacteria. Applied and Environmental Microbiology, july, vol. 64, n. 7, p. 2432-2438, 1998.

VAN LOODSTRECHT, M.C.M.; LYKLEMA, J.; NORDE, W.; SCHRAA, G.; ZEHNDER, A.J.B. Eletrophoretic mobility and hydrophobicity as a measure to predict the initial steps of bacterial adhesion. Applied and Environmental Microbiology, v. 53, p. 1898-1901, 1987.

VAN LOODSTRECHT, M.C.M.; LYKLEMA, J.; NORDE, W.; ZEHNDER, A.J.B. Influence of interfaces on microbial activity. Microbial Rewiews, v. 54, p. 75-87, 1990.

VEERESH, G.S.; KUMAR, P.; MEHROTRA, I. Treatment of phenol and cresols in upflowanaerobic sludge blanket (UASB) process: a review. Water Research. 39: 154-170, 2005.

VERRIER, D.; MORTIER, B.; ALBAGNAC, G. Initial adhesion of methanogenic bacteria to polymers. Biotechnology Letters. 9, p.735-742, 1987.

WANG, Y.T.; SUIDAN, M. T.; RITTMAN, B.E. Anaerobic treatment of phenol by an expanded-bed reactor. J. Wat. Poll. Cont. Fed., 58(3): 227-233, 1986. 
ANEXO A 
Tabela A.1 - Valores de vazão de alimentação durante a operação continua do reator anaeróbio de leito fluidificado preenchido com partículas de poliestireno.

\begin{tabular}{|c|c|}
\hline Dia & $\begin{array}{c}\text { vazão } \\
(\mathrm{mL} / \mathrm{h}) \\
\text { poliestireno }\end{array}$ \\
\hline 0 & 170 \\
\hline 1 & 187 \\
\hline 2 & 176 \\
\hline 3 & 165 \\
\hline 4 & 179 \\
\hline 5 & 170 \\
\hline 6 & 162 \\
\hline 7 & 166 \\
\hline 8 & 154 \\
\hline 9 & 186 \\
\hline 10 & 175 \\
\hline 11 & 172 \\
\hline 12 & 165 \\
\hline 13 & 172 \\
\hline 14 & 185 \\
\hline 15 & 182 \\
\hline 16 & 177 \\
\hline 19 & 172 \\
\hline 20 & 155 \\
\hline 21 & 163 \\
\hline 22 & 149 \\
\hline 23 & 286 \\
\hline 24 & 196 \\
\hline 25 & 190 \\
\hline 27 & 190 \\
\hline 28 & 181 \\
\hline 29 & 168 \\
\hline 30 & 186 \\
\hline 31 & 190 \\
\hline 33 & 203 \\
\hline 34 & 184 \\
\hline 35 & 188 \\
\hline 36 & 200 \\
\hline 37 & 159 \\
\hline 41 & 135 \\
\hline 42 & 178 \\
\hline
\end{tabular}


Tabela A.1 - Valores de vazão de alimentação durante a operação continua do reator anaeróbio de leito fluidificado preenchido com partículas de poliestireno (Continuação).

\begin{tabular}{|c|c|}
\hline Dia & $\begin{array}{c}\text { vazão } \\
(\mathrm{mL} / \mathrm{h}) \\
\text { poliestireno }\end{array}$ \\
\hline 43 & 168 \\
\hline 44 & 158 \\
\hline 45 & 157 \\
\hline 46 & 120 \\
\hline 47 & 147 \\
\hline 48 & 175 \\
\hline 49 & 191 \\
\hline 50 & 209 \\
\hline 51 & 170 \\
\hline 53 & 185 \\
\hline 54 & 205 \\
\hline 55 & 202 \\
\hline 56 & 234 \\
\hline 57 & 217 \\
\hline 58 & 142 \\
\hline 59 & 141 \\
\hline 60 & 169 \\
\hline 61 & 165 \\
\hline 62 & 158 \\
\hline 63 & 161 \\
\hline 64 & 139 \\
\hline 65 & 215 \\
\hline 68 & 192 \\
\hline 69 & 149 \\
\hline 70 & 225 \\
\hline 71 & 158 \\
\hline 72 & 208 \\
\hline 73 & 189 \\
\hline 74 & 153 \\
\hline 75 & 248 \\
\hline 76 & 160 \\
\hline 77 & 202 \\
\hline 84 & 169 \\
\hline 85 & 184 \\
\hline 86 & 143 \\
\hline 87 & 200 \\
\hline
\end{tabular}


Tabela A.1 - Valores de vazão de alimentação durante a operação continua do reator anaeróbio de leito fluidificado preenchido com partículas de poliestireno (Continuação).

\begin{tabular}{cc}
\hline & $\begin{array}{c}\text { vazão } \\
(\mathrm{mL} / \mathrm{h})\end{array}$ \\
Dia & poliestireno \\
\hline 88 & 178 \\
89 & 198 \\
90 & 163 \\
91 & 172 \\
92 & 212 \\
93 & 190 \\
94 & 160 \\
95 & 143 \\
96 & 179 \\
97 & 183 \\
98 & 140 \\
99 & 157 \\
100 & 184 \\
101 & 215 \\
102 & 210 \\
103 & 164 \\
104 & 171 \\
105 & 165 \\
106 & 186 \\
107 & 135 \\
108 & 197 \\
109 & 180 \\
110 & 174 \\
111 & 168 \\
112 & 166 \\
113 & 185 \\
114 & 136 \\
116 & 170 \\
117 & 132 \\
118 & 153 \\
119 & 182 \\
120 & 140 \\
121 & 177 \\
122 & 139 \\
123 & 133 \\
124 &
\end{tabular}


Tabela A.1 - Valores de vazão de alimentação durante a operação continua do reator anaeróbio de leito fluidificado preenchido com partículas de poliestireno (Continuação).

\begin{tabular}{|c|c|}
\hline Dia & $\begin{array}{c}\text { vazão } \\
(\mathrm{mL} / \mathrm{h}) \\
\text { poliestireno }\end{array}$ \\
\hline 125 & 180 \\
\hline 126 & 135 \\
\hline 127 & 130 \\
\hline 128 & 135 \\
\hline 129 & 171 \\
\hline 130 & 176 \\
\hline 131 & 143 \\
\hline 132 & 140 \\
\hline 133 & 143 \\
\hline 134 & 170 \\
\hline 135 & 152 \\
\hline 136 & 160 \\
\hline 137 & 161 \\
\hline 138 & 198 \\
\hline 139 & 137 \\
\hline 140 & 118 \\
\hline 141 & 164 \\
\hline 142 & 171 \\
\hline 143 & 130 \\
\hline 144 & 168 \\
\hline 145 & 131 \\
\hline 146 & 133 \\
\hline 147 & 167 \\
\hline 148 & 113 \\
\hline 149 & 133 \\
\hline 150 & 167 \\
\hline 151 & 150 \\
\hline 152 & 134 \\
\hline 153 & 133 \\
\hline 154 & 180 \\
\hline 155 & 159 \\
\hline 156 & 163 \\
\hline 157 & 167 \\
\hline 158 & 180 \\
\hline 159 & 130 \\
\hline 160 & 169 \\
\hline
\end{tabular}


Tabela A.1 - Valores de vazão de alimentação durante a operação continua do reator anaeróbio de leito fluidificado preenchido com partículas de poliestireno (Continuação).

\begin{tabular}{cc}
\hline & $\begin{array}{c}\text { vazão } \\
\text { (mL/h) } \\
\text { poliestireno }\end{array}$ \\
Dia & 168 \\
161 & 148 \\
162 & 175 \\
163 & 170 \\
164 & 180 \\
165 & 125 \\
166 & 167 \\
167 & 150 \\
168 & 133 \\
169 & 150 \\
170 & 164 \\
171 & 160 \\
172 & 164 \\
173 & 150 \\
174 & 184 \\
175 & 163 \\
176 & 167 \\
177 & 160 \\
178 & 170 \\
179 & 167 \\
180 & 171 \\
181 & 180 \\
182 &
\end{tabular}


Tabela A.2 - Valores da concentração de fenol e eficiência de remoção durante a operação contínua do reator anaeróbio de leito fluidificado preenchido com partículas de poliestireno.

\begin{tabular}{|c|c|c|c|}
\hline \multirow[b]{2}{*}{ Dia } & \multicolumn{2}{|c|}{ Concentração de fenol (mg/L) } & \multirow[b]{2}{*}{$\%$ removida } \\
\hline & afluente & Efluente & \\
\hline 0 & 51,51 & 0,98 & 98,1 \\
\hline 2 & 50,45 & 0,74 & 98,5 \\
\hline 5 & 51,04 & 0,21 & 99,6 \\
\hline 7 & 53,09 & 0,51 & 99,0 \\
\hline 9 & 51,56 & 0,63 & 98,8 \\
\hline 12 & 53,03 & 0,21 & 99,6 \\
\hline 14 & 109,90 & 0,51 & 99,5 \\
\hline 15 & 102,07 & 1,13 & 98,9 \\
\hline 21 & 109,58 & 1,60 & 98,5 \\
\hline 23 & 105,95 & 23,79 & 77,5 \\
\hline 25 & 102,19 & 0,66 & 99,4 \\
\hline 28 & 104,19 & 1,60 & 98,5 \\
\hline 30 & 106,77 & 1,60 & 98,5 \\
\hline 33 & 103,48 & 1,13 & 98,9 \\
\hline 37 & 107,35 & 35,64 & 66,8 \\
\hline 42 & 106,42 & 1,37 & 98,7 \\
\hline 44 & 110,17 & 1,25 & 98,9 \\
\hline 47 & 101,02 & 1,02 & 99,0 \\
\hline 49 & 103,60 & 0,43 & 99,6 \\
\hline 51 & 100,78 & 1,49 & 98,5 \\
\hline 54 & 99,84 & 0,43 & 99,6 \\
\hline 56 & 100,90 & 0,43 & 99,6 \\
\hline 58 & 201,09 & 1,33 & 99,3 \\
\hline 59 & 300,37 & 25,43 & 91,5 \\
\hline 61 & 278,36 & 126,07 & 54,7 \\
\hline 62 & 293,33 & 170,97 & 41,7 \\
\hline 63 & 311,81 & 183,00 & 41,3 \\
\hline 64 & 308,59 & 87,34 & 71,7 \\
\hline 65 & 310,64 & 24,25 & 92,2 \\
\hline 68 & 302,72 & 177,13 & 41,5 \\
\hline 69 & 305,36 & 171,55 & 43,8 \\
\hline 70 & 300,66 & 229,65 & 23,6 \\
\hline 71 & 309,17 & 97,32 & 68,5 \\
\hline 72 & 296,26 & 31,30 & 89,4 \\
\hline 75 & 290,98 & 58,58 & 79,9 \\
\hline 77 & 294,21 & 176,54 & 40,0 \\
\hline
\end{tabular}


Tabela A.2 - Valores da concentração de fenol e eficiência de remoção durante a operação contínua do reator anaeróbio de leito fluidificado preenchido com partículas de poliestireno (Continuação).

\begin{tabular}{|c|c|c|c|}
\hline \multirow[b]{2}{*}{ Dia } & \multicolumn{2}{|c|}{ Concentração de fenol (mg/L) } & \multirow[b]{2}{*}{$\%$ removida } \\
\hline & afluente & Efluente & \\
\hline 84 & 99,08 & 27,19 & 72,6 \\
\hline 85 & 99,66 & 24,25 & 75,7 \\
\hline 86 & 147,79 & 1,95 & 98,7 \\
\hline 87 & 148,08 & 4,59 & 96,9 \\
\hline 88 & 196,20 & 1,66 & 99,2 \\
\hline 89 & 227,01 & 1,66 & 99,3 \\
\hline 90 & 282,76 & 15,16 & 94,6 \\
\hline 91 & 268,68 & 10,46 & 96,1 \\
\hline 92 & 317,68 & 130,77 & 58,8 \\
\hline 93 & 316,51 & 2,25 & 99,3 \\
\hline 96 & 317,09 & 88,81 & 72,0 \\
\hline 98 & 337,63 & 64,45 & 80,9 \\
\hline 100 & 315,63 & 131,35 & 58,4 \\
\hline 103 & 324,43 & 69,44 & 78,6 \\
\hline 105 & 330,59 & 45,09 & 86,4 \\
\hline 106 & 327,36 & 27,48 & 91,6 \\
\hline 107 & 315,92 & 1,07 & 99,7 \\
\hline 110 & 285,11 & 1,07 & 99,6 \\
\hline 112 & 312,69 & 1,07 & 99,7 \\
\hline 114 & 303,30 & 1,07 & 99,6 \\
\hline 117 & 295,09 & 1,07 & 99,6 \\
\hline 119 & 432,41 & 90,86 & 79,0 \\
\hline 120 & 406,88 & 72,96 & 82,1 \\
\hline 121 & 432,41 & 86,46 & 80,0 \\
\hline 124 & 417,74 & 83,23 & 80,1 \\
\hline 125 & 417,74 & 82,94 & 80,1 \\
\hline 126 & 418,03 & 85,87 & 79,5 \\
\hline 127 & 394,27 & 78,83 & 80,0 \\
\hline 128 & 400,13 & 1,07 & 99,7 \\
\hline 129 & 522,10 & 10,36 & 98,0 \\
\hline 131 & 544,99 & 5,08 & 99,1 \\
\hline 133 & 501,56 & 2,14 & 99,6 \\
\hline 135 & 512,71 & 2,14 & 99,6 \\
\hline 138 & 501,56 & 2,14 & 99,6 \\
\hline 140 & 506,84 & 2,14 & 99,6 \\
\hline 142 & 499,21 & 2,14 & 99,6 \\
\hline
\end{tabular}


Tabela A.2 - Valores da concentração de fenol e eficiência de remoção durante a operação contínua do reator anaeróbio de leito fluidificado preenchido com partículas de poliestireno (Continuação).

\begin{tabular}{cccc}
\hline & \multicolumn{2}{c}{ Concentração de fenol $(\mathrm{mg} / \mathrm{L})$} & \\
\cline { 2 - 3 } Dia & afluente & Efluente & \% removida \\
\hline 145 & 547,33 & 2,14 & 99,6 \\
147 & 508,01 & 2,14 & 99,6 \\
149 & 508,01 & 2,14 & 99,6 \\
152 & 608,95 & 34,42 & 94,3 \\
153 & 618,93 & 34,42 & 94,4 \\
154 & 621,28 & 113,65 & 81,7 \\
155 & 621,28 & 113,65 & 81,7 \\
156 & 608,95 & 60,24 & 90,1 \\
157 & 610,13 & 40,29 & 93,4 \\
158 & 720,46 & 225,15 & 68,7 \\
159 & 722,60 & 239,03 & 66,9 \\
161 & 710,86 & 241,38 & 66,0 \\
163 & 710,86 & 282,46 & 60,3 \\
166 & 709,69 & 239,03 & 66,3 \\
169 & 708,52 & 174,48 & 75,4 \\
173 & 708,52 & 139,27 & 80,3 \\
175 & 709,69 & 212,04 & 70,1 \\
177 & 719,08 & 167,43 & 76,7 \\
180 & 714,38 & 71,19 & 90,0 \\
182 & 712,04 & 34,80 & 95,1 \\
\hline
\end{tabular}


Tabela A.3 - Valores de DQO e eficiência de redução durante a operação contínua do reator anaeróbio de leito fluidificado preenchido com partículas de poliestireno.

\begin{tabular}{ccccc}
\hline & DQO $(\mathrm{mg} / \mathrm{L})$ & & \\
\cline { 2 - 2 } Dia & afluente & efluente & \% reduzida \\
\hline 0 & 602,40 & 109,56 & 81,81 \\
2 & 603,87 & 25,71 & 95,74 \\
5 & 533,25 & 37,47 & 92,97 \\
7 & 572,97 & 69,84 & 87,81 \\
9 & 584,74 & 34,53 & 94,09 \\
12 & 645,06 & 8,05 & 98,75 \\
14 & 733,33 & 12,47 & 98,30 \\
15 & 687,72 & 33,06 & 95,19 \\
21 & 764,22 & 18,35 & 97,60 \\
23 & 792,18 & 184,59 & 76,70 \\
25 & 770,11 & 31,59 & 95,90 \\
28 & 768,64 & 56,60 & 92,64 \\
30 & 837,78 & 88,97 & 89,38 \\
33 & 801,00 & 144,87 & 81,91 \\
37 & 856,91 & 294,93 & 65,58 \\
42 & 765,69 & 13,94 & 98,18 \\
44 & 717,15 & 30,12 & 95,80 \\
47 & 714,20 & 71,31 & 90,02 \\
49 & 543,55 & 52,19 & 90,40 \\
51 & 531,78 & 37,47 & 92,95 \\
54 & 567,09 & 59,54 & 89,50 \\
56 & 595,04 & 43,36 & 92,71 \\
58 & 870,15 & 34,53 & 96,03 \\
59 & 1029,03 & 127,22 & 87,64 \\
61 & 992,63 & 168,79 & 83,00 \\
62 & 1066,19 & 345,33 & 67,61 \\
63 & 948,50 & 301,19 & 68,25 \\
65 & 1080,90 & 6,96 & 99,36 \\
68 & 1051,48 & 154,08 & 85,35 \\
70 & 1228,02 & 639,56 & 47,92 \\
72 & 1007,34 & 0,34 & 99,97 \\
75 & 830,81 & 0,34 & 99,96 \\
77 & 1356,94 & 731,70 & 46,08 \\
84 & 768,48 & 216,80 & 71,79 \\
86 & 871,46 & 0,54 & 99,94 \\
87 & 783,19 & 0,17 & 99,98 \\
88 & 1024,19 & 0,09 & 99,99 \\
\hline & & &
\end{tabular}


Tabela A.3 - Valores de DQO e eficiência de redução durante a operação contínua do reator anaeróbio de leito fluidificado preenchido com partículas de poliestireno (Continuação).

\begin{tabular}{|c|c|c|c|}
\hline & DQO (mg/L) & & \\
\hline Dia & afluente & efluente & $\%$ reduzida \\
\hline 89 & 1068,32 & 1,74 & 99,84 \\
\hline 90 & 1186,02 & 20,13 & 98,30 \\
\hline 91 & 1123,49 & 16,45 & 98,54 \\
\hline 92 & 1476,57 & 424,70 & 71,24 \\
\hline 96 & 1388,30 & 237,12 & 82,92 \\
\hline 97 & 1263,25 & 229,77 & 81,81 \\
\hline 98 & 1366,23 & 152,53 & 88,84 \\
\hline 99 & 1296,35 & 226,09 & 82,56 \\
\hline 100 & 1380,94 & 387,92 & 71,91 \\
\hline 103 & 1300,03 & 185,63 & 85,72 \\
\hline 105 & 1285,32 & 435,73 & 66,10 \\
\hline 107 & 1230,15 & 0,00 & 100,00 \\
\hline 110 & 1046,26 & 1,74 & 99,83 \\
\hline 111 & 1300,03 & 56,91 & 95,62 \\
\hline 112 & 1314,74 & 189,31 & 85,60 \\
\hline 114 & 1318,42 & 185,63 & 85,92 \\
\hline 117 & 1182,34 & 0,01 & 100,00 \\
\hline 119 & 1774,48 & 292,29 & 83,53 \\
\hline 120 & 1384,62 & 123,11 & 91,11 \\
\hline 121 & 1241,19 & 167,24 & 86,53 \\
\hline 124 & 1226,47 & 218,73 & 82,17 \\
\hline 125 & 1678,85 & 292,29 & 82,59 \\
\hline 126 & 1616,33 & 273,90 & 83,05 \\
\hline 127 & 1461,86 & 292,29 & 80,01 \\
\hline 128 & 1535,42 & 0,00 & 100,00 \\
\hline 129 & 2261,70 & 3,48 & 99,85 \\
\hline 131 & 2033,67 & 0,06 & 100,00 \\
\hline 133 & 2018,96 & 0,00 & 100,00 \\
\hline 135 & 1901,27 & 0,00 & 100,00 \\
\hline 138 & 1871,84 & 0,00 & 100,00 \\
\hline 140 & 1930,69 & 0,00 & 100,00 \\
\hline 142 & 1893,91 & 0,00 & 100,00 \\
\hline 145 & 1798,28 & 0,00 & 100,00 \\
\hline 147 & 1849,78 & 0,00 & 100,00 \\
\hline 149 & 1908,62 & 0,00 & 100,00 \\
\hline 152 & 2195,50 & 0,00 & 100,00 \\
\hline
\end{tabular}


Tabela A.3 - Valores de DQO e eficiência de redução durante a operação contínua do reator anaeróbio de leito fluidificado preenchido com partículas de poliestireno (Continuação).

\begin{tabular}{|c|c|c|c|}
\hline & $\mathrm{DQO}(\mathrm{mg} / \mathrm{L})$ & & \\
\hline Dia & afluente & efluente & $\%$ reduzida \\
\hline 154 & 2276,41 & 334,49 & 85,31 \\
\hline 155 & 2298,48 & 260,93 & 88,65 \\
\hline 156 & 2342,61 & 621,36 & 73,48 \\
\hline 158 & 2313,19 & 753,77 & 67,41 \\
\hline 159 & 2239,63 & 753,77 & 66,34 \\
\hline 161 & 2232,27 & 819,97 & 63,27 \\
\hline 163 & 2482,37 & 915,59 & 63,12 \\
\hline 166 & 2445,59 & 893,53 & 63,46 \\
\hline 169 & 2379,39 & 621,36 & 73,89 \\
\hline 173 & 2401,46 & 496,32 & 79,33 \\
\hline 175 & 2408,81 & 739,06 & 69,32 \\
\hline 177 & 2430,88 & 599,30 & 75,35 \\
\hline 180 & 2519,15 & 165,31 & 93,44 \\
\hline 182 & 2349,97 & 143,24 & 93,90 \\
\hline
\end{tabular}


Tabela A.4 - Valores de pH durante a operação contínua do reator anaeróbio de leito fluidizado preenchido com partículas de poliestireno.

\begin{tabular}{ccc}
\hline & \multicolumn{2}{c}{$\mathrm{pH}$} \\
\cline { 2 - 3 } Dia & afluente & efluente \\
\hline 0 & 7,01 & 8,21 \\
1 & 7,16 & 8,21 \\
2 & 7,28 & 7,98 \\
3 & 7,25 & 8,15 \\
4 & 7,68 & 8,13 \\
5 & 7,74 & 8,15 \\
6 & 7,04 & 8,14 \\
7 & 7,56 & 8,16 \\
8 & 7,41 & 8,13 \\
9 & 7,22 & 8,10 \\
10 & 7,17 & 8,06 \\
11 & 7,18 & 8,10 \\
12 & 7,15 & 8,11 \\
13 & 7,07 & 8,20 \\
14 & 7,13 & 8,10 \\
15 & 7,33 & 8,14 \\
16 & 7,19 & 8,21 \\
19 & 7,10 & 8,05 \\
21 & 7,17 & 8,01 \\
22 & 7,46 & 8,09 \\
23 & 7,17 & 7,64 \\
27 & 7,11 & 8,06 \\
28 & 7,00 & 7,95 \\
29 & 7,02 & 7,85 \\
30 & 7,50 & 7,91 \\
31 & 7,35 & 7,93 \\
33 & 7,40 & 7,88 \\
34 & 7,35 & 7,85 \\
35 & 7,26 & 7,79 \\
36 & 7,20 & 7,50 \\
37 & 6,83 & 8,06 \\
42 & 6,93 & 8,08 \\
43 & 7,31 & 7,95 \\
44 & 6,94 & 8,08 \\
46 & 6,72 & 8,10 \\
47 & 7,15 & 8,05 \\
48 & 7,19 & 8,05 \\
\hline & &
\end{tabular}


Tabela A.4 - Valores de pH durante a operação contínua do reator anaeróbio de leito fluidizado preenchido com partículas de poliestireno.

\begin{tabular}{ccc}
\hline & \multicolumn{2}{c}{$\mathrm{pH}$} \\
\cline { 2 - 3 } Dia & afluente & efluente \\
\hline 49 & 7,35 & 8,03 \\
50 & 6,97 & 7,88 \\
51 & 7,48 & 8,07 \\
54 & 7,42 & 8,14 \\
56 & 7,59 & 7,95 \\
58 & 7,20 & 7,78 \\
59 & 7,23 & 7,84 \\
61 & 6,93 & 7,67 \\
62 & 7,22 & 7,83 \\
63 & 7,47 & 7,58 \\
64 & 6,99 & 7,78 \\
65 & 7,36 & 7,67 \\
68 & 6,64 & 7,64 \\
70 & 6,92 & 7,89 \\
71 & 7,32 & 7,67 \\
72 & 6,75 & 7,80 \\
74 & 7,31 & 7,74 \\
75 & 7,31 & 7,67 \\
76 & 6,88 & 7,67 \\
77 & 7,02 & 7,19 \\
84 & 6,96 & 8,02 \\
85 & 7,46 & 7,65 \\
86 & 6,85 & 8,10 \\
87 & 7,20 & 7,91 \\
88 & 6,79 & 7,87 \\
89 & 7,04 & 8,13 \\
90 & 6,89 & 7,71 \\
91 & 7,19 & 7,73 \\
92 & 6,84 & 7,98 \\
93 & 7,36 & 7,87 \\
94 & 6,63 & 8,03 \\
96 & 6,85 & 7,90 \\
97 & 7,22 & 7,62 \\
98 & 7,16 & 7,84 \\
99 & 7,16 & 7,90 \\
100 & 6,86 & 7,83 \\
101 & 7,17 & 7,75 \\
\hline & &
\end{tabular}


Tabela A.4 - Valores de pH durante a operação contínua do reator anaeróbio de leito fluidizado preenchido com partículas de poliestireno.

\begin{tabular}{ccc}
\hline & \multicolumn{2}{c}{$\mathrm{pH}$} \\
\cline { 2 - 3 } Dia & afluente & efluente \\
\hline 103 & 7,11 & 7,62 \\
104 & 6,7 & 8,00 \\
105 & 7,23 & 7,77 \\
106 & 7,15 & 7,76 \\
107 & 7,06 & 7,73 \\
110 & 6,99 & 8,03 \\
112 & 7,19 & 7,74 \\
114 & 7,02 & 8,12 \\
116 & 7,04 & 8,21 \\
117 & 7,01 & 8,07 \\
118 & 7,2 & 7,98 \\
119 & 7,33 & 7,89 \\
120 & 7,12 & 7,68 \\
121 & 7,12 & 7,7 \\
122 & 6,66 & 7,58 \\
123 & 7,08 & 7,61 \\
124 & 7,19 & 7,64 \\
125 & 6,8 & 7,63 \\
126 & 7,02 & 7,9 \\
127 & 7,1 & 7,8 \\
128 & 6,91 & 7,53 \\
129 & 6,9 & 7,62 \\
130 & 7,05 & 7,89 \\
131 & 7,07 & 8,08 \\
132 & 6,89 & 7,73 \\
133 & 6,85 & 7,73 \\
134 & 7,17 & 7,34 \\
135 & 7,02 & 7,68 \\
136 & 7,1 & 7,89 \\
137 & 6,95 & 7,95 \\
138 & 6,81 & 8,05 \\
139 & 7,9 & 8 \\
140 & 7,02 & 8,05 \\
141 & 6,9 & 7,85 \\
142 & 6,77 & 7,61 \\
143 & 6,81 & 7,38 \\
144 & 6,81 & 7,8 \\
145 & 7,13 & 7,83 \\
\hline & &
\end{tabular}


Tabela A.4 - Valores de pH durante a operação contínua do reator anaeróbio de leito fluidizado preenchido com partículas de poliestireno.

\begin{tabular}{ccc}
\hline & \multicolumn{2}{c}{$\mathrm{pH}$} \\
\cline { 2 - 3 } Dia & afluente & efluente \\
\hline 146 & 6,6 & 7,29 \\
147 & 6,73 & 7,82 \\
148 & 7 & 7,3 \\
149 & 6,93 & 8,06 \\
150 & 6,85 & 7,92 \\
151 & 6,77 & 7,86 \\
152 & 6,62 & 7,81 \\
153 & 7,2 & 7,77 \\
154 & 7,1 & 7,8 \\
155 & 7,19 & 7,77 \\
156 & 7,11 & 7,75 \\
157 & 7,22 & 7,8 \\
158 & 6,59 & 7,82 \\
159 & 7,05 & 7,8 \\
160 & 7,08 & 7,86 \\
161 & 7,14 & 7,72 \\
162 & 6,64 & 7,33 \\
163 & 7,05 & 7,95 \\
164 & 7,5 & 8,03 \\
165 & 7,36 & 7,86 \\
166 & 7,09 & 7,91 \\
167 & 6,9 & 7,95 \\
168 & 6,99 & 7,79 \\
169 & 6,89 & 7,82 \\
170 & 6,81 & 7,71 \\
171 & 6,95 & 7,76 \\
172 & 6,9 & 7,85 \\
173 & 7,21 & 7,79 \\
174 & 7,17 & 7,8 \\
175 & 7,12 & 7,81 \\
176 & 7,05 & 7,79 \\
177 & 6,91 & 7,8 \\
178 & 6,9 & 7,81 \\
179 & 6,87 & 7,8 \\
180 & 6,89 & 7,83 \\
181 & 6,93 & 7,68 \\
182 & 7,00 & 7,61 \\
\hline & &
\end{tabular}


Tabela A.5 - Valores de concentração de alcalinidade a bicarbonato durante a operação continua do reator preenchido com partículas de poliestireno.

\begin{tabular}{|c|c|c|}
\hline & \multicolumn{2}{|c|}{ Alcalinidade a bicarbonato $(\mathrm{mg} / \mathrm{L})$} \\
\hline & \multicolumn{2}{|c|}{ Poliestireno } \\
\hline Dia & afluente & efluente \\
\hline 0 & 72,56 & 796,35 \\
\hline 2 & 57,89 & 352,19 \\
\hline 5 & 212,34 & 284,24 \\
\hline 7 & 209,27 & 297,37 \\
\hline 12 & 310,51 & 306,64 \\
\hline 14 & 110,37 & 288,10 \\
\hline 15 & 220,81 & 297,37 \\
\hline 16 & 249,42 & 301,24 \\
\hline 21 & 131,25 & 288,10 \\
\hline 28 & 83,36 & 291,97 \\
\hline 30 & 79,49 & 282,70 \\
\hline 33 & 131,25 & 269,56 \\
\hline 35 & 131,25 & 269,56 \\
\hline 42 & 128,11 & 293,91 \\
\hline 44 & 106,54 & 281,93 \\
\hline 47 & 189,13 & 305,11 \\
\hline 49 & 192,67 & 249,49 \\
\hline 54 & 185,33 & 249,49 \\
\hline 56 & 172,96 & 244,09 \\
\hline 58 & 129,71 & 228,25 \\
\hline 59 & 134,35 & 226,31 \\
\hline 61 & 111,17 & 223,61 \\
\hline 63 & 203,51 & 242,15 \\
\hline 68 & 125,81 & 286,57 \\
\hline 70 & 60,55 & 278,43 \\
\hline 75 & 232,42 & 288,10 \\
\hline 77 & 213,11 & 285,40 \\
\hline 84 & 121,18 & 364,96 \\
\hline 87 & 201,47 & 305,88 \\
\hline 88 & 113,44 & 301,24 \\
\hline 89 & 218,48 & 272,66 \\
\hline 90 & 131,58 & 295,84 \\
\hline
\end{tabular}


Tabela A.5 - Valores de concentração de alcalinidade a bicarbonato durante a operação continua do reator preenchido com partículas de poliestireno (Continuação).

\begin{tabular}{|c|c|c|}
\hline & \multicolumn{2}{|c|}{ Alcalinidade a bicarbonato $(\mathrm{mg} / \mathrm{L})$} \\
\hline & \multicolumn{2}{|c|}{ Poliestireno } \\
\hline Dia & afluente & efluente \\
\hline 92 & 101,84 & 293,51 \\
\hline 96 & 128,11 & 315,15 \\
\hline 97 & 199,94 & 311,28 \\
\hline 98 & 166,73 & 308,58 \\
\hline 99 & 189,13 & 299,71 \\
\hline 100 & 82,53 & 291,97 \\
\hline 103 & 207,67 & 288,10 \\
\hline 105 & 188,33 & 291,97 \\
\hline 110 & 239,35 & 288,10 \\
\hline 112 & 204,57 & 274,97 \\
\hline 117 & 251,72 & 301,24 \\
\hline 119 & 162,86 & 287,34 \\
\hline 120 & 199,17 & 292,74 \\
\hline 121 & 234,32 & 282,70 \\
\hline 124 & 214,64 & 303,18 \\
\hline 125 & 202,27 & 287,34 \\
\hline 126 & 198,40 & 290,04 \\
\hline 127 & 194,54 & 278,83 \\
\hline 128 & 177,16 & 264,93 \\
\hline 129 & 84,10 & 275,73 \\
\hline 131 & 237,82 & 282,70 \\
\hline 133 & 265,66 & 291,97 \\
\hline 138 & 304,31 & 295,84 \\
\hline 140 & 207,27 & 282,70 \\
\hline 145 & 225,45 & 295,84 \\
\hline 147 & 216,94 & 293,91 \\
\hline 152 & 166,73 & 287,34 \\
\hline 154 & 182,57 & 299,31 \\
\hline 159 & 181,40 & 293,51 \\
\hline 161 & 197,24 & 288,10 \\
\hline 166 & 228,55 & 273,43 \\
\hline 169 & 243,22 & 288,10 \\
\hline
\end{tabular}


Tabela A.5 - Valores de concentração de alcalinidade a bicarbonato durante a operação continua do reator preenchido com partículas de poliestireno (Continuação).

\begin{tabular}{ccc}
\hline & \multicolumn{2}{c}{ Alcalinidade a bicarbonato $(\mathrm{mg} / \mathrm{L})$} \\
\cline { 2 - 3 } Dia & \multicolumn{2}{c}{ Poliestireno } \\
\hline 173 & 233,95 & efluente \\
175 & 244,75 & 276,132 \\
180 & 248,62 & 288,10 \\
182 & 275,70 & 273,43 \\
\hline
\end{tabular}


Tabela A.6 - Valores de concentração de ácidos voláteis totais durante a operação continua do reator preenchido com partículas de poliestireno.

\begin{tabular}{|c|c|c|}
\hline \multirow[b]{3}{*}{ Dia } & \multicolumn{2}{|c|}{ Ácidos voláteis totais $(\mathrm{mgHac} / \mathrm{L})$} \\
\hline & \multicolumn{2}{|c|}{ Poliestireno } \\
\hline & afluente & Efluente \\
\hline 0 & 54,48 & 92,62 \\
\hline 2 & 49,03 & 65,38 \\
\hline 5 & 92,62 & 43,58 \\
\hline 7 & 70,82 & 38,14 \\
\hline 12 & 32,69 & 38,14 \\
\hline 14 & 92,62 & 38,14 \\
\hline 15 & 119,86 & 38,14 \\
\hline 16 & 92,62 & 32,69 \\
\hline 21 & 76,27 & 38,14 \\
\hline 28 & 65,38 & 32,69 \\
\hline 30 & 70,82 & 32,69 \\
\hline 33 & 76,27 & 38,14 \\
\hline 35 & 76,27 & 38,14 \\
\hline 42 & 119,86 & 29,96 \\
\hline 44 & 65,38 & 27,24 \\
\hline 47 & 125,30 & 27,24 \\
\hline 49 & 68,10 & 27,24 \\
\hline 54 & 65,38 & 27,24 \\
\hline 56 & 76,27 & 21,79 \\
\hline 58 & 65,38 & 24,52 \\
\hline 59 & 65,38 & 27,24 \\
\hline 61 & 65,38 & 24,52 \\
\hline 63 & 46,31 & 24,52 \\
\hline 68 & 103,51 & 27,24 \\
\hline 70 & 84,44 & 51,76 \\
\hline 75 & 103,51 & 38,14 \\
\hline 77 & 98,06 & 35,41 \\
\hline 84 & 103,51 & 40,86 \\
\hline 87 & 147,10 & 32,69 \\
\hline 88 & 114,41 & 32,69 \\
\hline 89 & 136,20 & 27,24 \\
\hline 90 & 128,03 & 27,24 \\
\hline
\end{tabular}


Tabela A.6 - Valores de concentração de ácidos voláteis totais durante a operação continua do reator preenchido com partículas de poliestireno (Continuação).

\begin{tabular}{|c|c|c|}
\hline \multirow[b]{3}{*}{ Dia } & \multicolumn{2}{|c|}{ Ácidos voláteis totais (mgHac/L) } \\
\hline & \multicolumn{2}{|c|}{ Poliestireno } \\
\hline & afluente & Efluente \\
\hline 92 & 130,75 & 43,58 \\
\hline 96 & 119,86 & 32,69 \\
\hline 97 & 136,20 & 38,14 \\
\hline 98 & 130,75 & 35,41 \\
\hline 99 & 125,30 & 21,79 \\
\hline 100 & 125,30 & 32,69 \\
\hline 103 & 125,30 & 38,14 \\
\hline 105 & 152,54 & 32,69 \\
\hline 110 & 119,86 & 38,14 \\
\hline 112 & 136,20 & 43,58 \\
\hline 117 & 108,96 & 32,69 \\
\hline 119 & 136,20 & 32,69 \\
\hline 120 & 130,75 & 38,14 \\
\hline 121 & 133,48 & 32,69 \\
\hline 124 & 108,96 & 29,96 \\
\hline 125 & 119,86 & 32,69 \\
\hline 126 & 125,30 & 35,41 \\
\hline 127 & 130,75 & 38,14 \\
\hline 128 & 122,58 & 38,14 \\
\hline 129 & 103,51 & 49,03 \\
\hline 131 & 108,96 & 32,69 \\
\hline 133 & 76,27 & 32,69 \\
\hline 138 & 54,48 & 27,24 \\
\hline 140 & 138,92 & 32,69 \\
\hline 145 & 119,86 & 27,24 \\
\hline 147 & 125,30 & 29,96 \\
\hline 152 & 130,75 & 32,69 \\
\hline 154 & 128,03 & 35,41 \\
\hline 159 & 136,20 & 43,58 \\
\hline 161 & 133,48 & 38,14 \\
\hline 166 & 108,96 & 32,69 \\
\hline 169 & 114,41 & 38,14 \\
\hline 173 & 114,41 & 35,41 \\
\hline 175 & 125,30 & 38,14 \\
\hline 180 & 119,86 & 32,69 \\
\hline 182 & 81,72 & 38,14 \\
\hline
\end{tabular}


Tabela A.7 - Valores da taxa de carregamento orgânico aplicado e removido durante a operação continua do reator preenchido com partículas de poliestireno.

\begin{tabular}{|c|c|c|c|}
\hline \multirow[b]{2}{*}{ Dia } & \multicolumn{2}{|c|}{ Taxa de carregamento orgânico ( $\mathrm{kg}$ de Fenol $/ \mathrm{m}^{3}$ dia) } & \multirow[b]{2}{*}{$\%$ removida } \\
\hline & aplicada & removida & \\
\hline 0 & 0,09 & 0,09 & 98,1 \\
\hline 2 & 0,09 & 0,09 & 98,5 \\
\hline 5 & 0,09 & 0,09 & 99,6 \\
\hline 7 & 0,09 & 0,09 & 99,0 \\
\hline 9 & 0,10 & 0,09 & 98,8 \\
\hline 12 & 0,09 & 0,09 & 99,6 \\
\hline 14 & 0,20 & 0,20 & 99,5 \\
\hline 15 & 0,18 & 0,18 & 98,9 \\
\hline 21 & 0,18 & 0,17 & 98,5 \\
\hline 23 & 0,30 & 0,23 & 77,5 \\
\hline 25 & 0,19 & 0,19 & 99,4 \\
\hline 28 & 0,19 & 0,18 & 98,5 \\
\hline 30 & 0,20 & 0,19 & 98,5 \\
\hline 33 & 0,21 & 0,21 & 98,9 \\
\hline 37 & 0,17 & 0,11 & 66,8 \\
\hline 42 & 0,19 & 0,19 & 98,7 \\
\hline 44 & 0,17 & 0,17 & 98,9 \\
\hline 47 & 0,15 & 0,15 & 99,0 \\
\hline 49 & 0,20 & 0,20 & 99,6 \\
\hline 51 & 0,17 & 0,17 & 98,5 \\
\hline 54 & 0,20 & 0,20 & 99,6 \\
\hline 56 & 0,23 & 0,23 & 99,6 \\
\hline 58 & 0,28 & 0,28 & 99,3 \\
\hline 59 & 0,42 & 0,38 & 91,5 \\
\hline 61 & 0,46 & 0,25 & 54,7 \\
\hline 62 & 0,46 & 0,19 & 41,7 \\
\hline 63 & 0,50 & 0,21 & 41,3 \\
\hline 64 & 0,43 & 0,31 & 71,7 \\
\hline 65 & 0,66 & 0,61 & 92,2 \\
\hline 68 & 0,58 & 0,24 & 41,5 \\
\hline 69 & 0,45 & 0,20 & 43,8 \\
\hline 70 & 0,67 & 0,16 & 23,6 \\
\hline 71 & 0,48 & 0,33 & 68,5 \\
\hline 72 & 0,61 & 0,55 & 89,4 \\
\hline 75 & 0,71 & 0,57 & 79,9 \\
\hline 77 & 0,59 & 0,24 & 40,0 \\
\hline 84 & 0,17 & 0,12 & 72,6 \\
\hline
\end{tabular}


Tabela A.7 - Valores da taxa de carregamento orgânico aplicado e removido durante a operação continua do reator preenchido com partículas de poliestireno (Continuação).

\begin{tabular}{|c|c|c|c|}
\hline \multirow[b]{2}{*}{ Dia } & \multicolumn{2}{|c|}{ Taxa de carregamento orgânico ( $\mathrm{kg}$ de Fenol $\left./ \mathrm{m}^{3} \mathrm{dia}\right)$} & \multirow[b]{2}{*}{$\%$ removida } \\
\hline & aplicada & removida & \\
\hline 85 & 0,18 & 0,14 & 75,7 \\
\hline 86 & 0,21 & 0,21 & 98,7 \\
\hline 87 & 0,29 & 0,28 & 96,9 \\
\hline 88 & 0,35 & 0,34 & 99,2 \\
\hline 89 & 0,45 & 0,44 & 99,3 \\
\hline 90 & 0,46 & 0,43 & 94,6 \\
\hline 91 & 0,46 & 0,44 & 96,1 \\
\hline 92 & 0,67 & 0,39 & 58,8 \\
\hline 93 & 0,60 & 0,59 & 99,3 \\
\hline 96 & 0,56 & 0,41 & 72,0 \\
\hline 98 & 0,47 & 0,38 & 80,9 \\
\hline 100 & 0,58 & 0,34 & 58,4 \\
\hline 103 & 0,53 & 0,42 & 78,6 \\
\hline 105 & 0,54 & 0,47 & 86,4 \\
\hline 106 & 0,61 & 0,55 & 91,6 \\
\hline 107 & 0,42 & 0,42 & 99,7 \\
\hline 110 & 0,49 & 0,49 & 99,6 \\
\hline 112 & 0,51 & 0,51 & 99,7 \\
\hline 114 & 0,41 & 0,41 & 99,6 \\
\hline 117 & 0,39 & 0,39 & 99,6 \\
\hline 119 & 0,78 & 0,62 & 79,0 \\
\hline 120 & 0,57 & 0,46 & 82,1 \\
\hline 121 & 0,76 & 0,61 & 80,0 \\
\hline 124 & 0,55 & 0,44 & 80,1 \\
\hline 125 & 0,75 & 0,60 & 80,1 \\
\hline 126 & 0,56 & 0,44 & 79,5 \\
\hline 127 & 0,51 & 0,41 & 80,0 \\
\hline 128 & 0,53 & 0,53 & 99,7 \\
\hline 129 & 0,88 & 0,87 & 98,0 \\
\hline 131 & 0,77 & 0,76 & 99,1 \\
\hline 133 & 0,71 & 0,71 & 99,6 \\
\hline 135 & 0,77 & 0,77 & 99,6 \\
\hline 138 & 0,98 & 0,98 & 99,6 \\
\hline 140 & 0,59 & 0,59 & 99,6 \\
\hline 142 & 0,85 & 0,84 & 99,6 \\
\hline 145 & 0,71 & 0,71 & 99,6 \\
\hline 147 & 0,84 & 0,84 & 99,6 \\
\hline 149 & 0,67 & 0,67 & 99,6 \\
\hline
\end{tabular}


Tabela A.7 - Valores da taxa de carregamento orgânico aplicado e removido durante a operação continua do reator preenchido com partículas de poliestireno (Continuação).

\begin{tabular}{rccc}
\hline & \multicolumn{2}{c}{ Taxa de carregamento orgânico $\left(\mathrm{kg} \mathrm{de} \mathrm{Fenol} / \mathrm{m}^{3}\right.$ dia $)$} & \\
\cline { 2 - 3 } Dia & aplicada & removida & \% removida \\
\hline 152 & 0,81 & 0,76 & 94,3 \\
153 & 0,82 & 0,77 & 94,4 \\
154 & 1,11 & 0,91 & 81,7 \\
155 & 0,98 & 0,80 & 81,7 \\
156 & 0,98 & 0,88 & 90,1 \\
157 & 1,01 & 0,94 & 93,4 \\
158 & 1,29 & 0,88 & 68,7 \\
159 & 0,93 & 0,62 & 66,9 \\
161 & 1,18 & 0,78 & 66,0 \\
163 & 1,23 & 0,74 & 60,3 \\
166 & 0,88 & 0,58 & 66,3 \\
169 & 0,94 & 0,71 & 75,4 \\
173 & 1,15 & 0,92 & 80,3 \\
175 & 1,29 & 0,91 & 70,1 \\
177 & 1,19 & 0,91 & 76,7 \\
180 & 1,18 & 1,06 & 90,0 \\
182 & 1,27 & 1,21 & 95,1 \\
\hline
\end{tabular}


Tabela A.8 - Valores dos Sólidos Suspensos Voláteis (SSV), Sólidos Suspensos Totais (SST) e Sólidos Suspensos Fixos (SSF) durante a operação continua do reator preenchido com partículas de poliestireno.

\begin{tabular}{|c|c|c|c|c|c|c|}
\hline \multirow[b]{2}{*}{ Dia } & \multicolumn{2}{|c|}{$\mathrm{SSV}(\mathrm{mg} / \mathrm{L})$} & \multicolumn{2}{|c|}{ SST (mg/L) } & \multicolumn{2}{|c|}{$\mathrm{SSF}(\mathrm{mg} / \mathrm{L})$} \\
\hline & afluente & efluente & afluente & efluente & afluente & Efluente \\
\hline 0 & 444 & 1240 & 728 & 1246 & 284 & 6 \\
\hline 5 & 152 & 134 & 348 & 390 & 196 & 256 \\
\hline 12 & 270 & 126 & 486 & 322 & 216 & 196 \\
\hline 14 & 380 & 364 & 586 & 428 & 206 & 64 \\
\hline 15 & 1000 & 158 & 466 & 290 & 534 & 132 \\
\hline 19 & 394 & 222 & 612 & 450 & 218 & 228 \\
\hline 25 & 356 & 468 & 484 & 422 & 128 & 46 \\
\hline 33 & 458 & 388 & 722 & 620 & 264 & 232 \\
\hline 42 & 338 & 332 & 530 & 426 & 192 & 94 \\
\hline 47 & 232 & 282 & 432 & 402 & 200 & 120 \\
\hline 54 & 196 & 286 & 330 & 344 & 134 & 58 \\
\hline 58 & 178 & 234 & 330 & 332 & 152 & 98 \\
\hline 59 & 196 & 142 & 294 & 272 & 98 & 130 \\
\hline 61 & 218 & 386 & 344 & 308 & 126 & 78 \\
\hline 70 & 354 & 298 & 678 & 528 & 324 & 230 \\
\hline 84 & 288 & 1306 & 430 & 614 & 142 & 692 \\
\hline 89 & 304 & 332 & 348 & 402 & 44 & 70 \\
\hline 96 & 268 & 444 & 460 & 488 & 192 & 44 \\
\hline 100 & 462 & 210 & 646 & 418 & 184 & 208 \\
\hline 103 & 492 & 404 & 478 & 422 & 14 & 18 \\
\hline 110 & 116 & 328 & 368 & 558 & 252 & 230 \\
\hline 117 & 420 & 168 & 442 & 390 & 22 & 222 \\
\hline 121 & 410 & 290 & 370 & 452 & 40 & 162 \\
\hline 129 & 412 & 746 & 610 & 886 & 198 & 140 \\
\hline 133 & 176 & 912 & 378 & 472 & 202 & 440 \\
\hline 138 & 184 & 554 & 338 & 438 & 154 & 116 \\
\hline 145 & 58 & 620 & 358 & 738 & 300 & 118 \\
\hline 155 & 130 & 526 & 392 & 476 & 262 & 50 \\
\hline 177 & 118 & 848 & 816 & 658 & 698 & 190 \\
\hline
\end{tabular}

